UNIVERSIDADE FEDERAL DE JUIZ DE FORA

FACULDADE DE DIREITO

PROGRAMA DE PÓS-GRADUAÇÃO STRICTO SENSU EM DIREITO

MESTRADO EM DIREITO E INOVAÇÃO

EDUARDO ATALLA BARLETTA

A PROVA EM VÍDEO NA JUSTIÇA DO TRABALHO: UM ESTUDO COMPARATIVO

JUIZ DE FORA/MG

2021

EDUARDO ATALLA BARLETTA 


\section{A PROVA EM VÍDEO NA JUSTIÇA DO TRABALHO: UM ESTUDO COMPARATIVO}

Dissertação apresentada ao Programa de PósGraduação em Direito e Inovação da Universidade Federal de Juiz de Fora como requisito parcial para a obtenção do grau de Mestre na área de concentração Direito, Argumentação e Inovação sob a orientação do Prof. Dr. Vicente Riccio. 
Ficha catalografica elaborada atraves do programa de goraçao automatica da Biblioteca Universitaria da UFJF, com os dados fomecidos pelo(a) autor(a)

Atalla Barletta, Eduardo.

A prova em video na Justiça do Trabalho : um estudo comparativo. / Eduardo Atalla Barletta. - 2021.

94 f. : il.

Orientador: Vicente Riccio

Dissertaçao (mestrado academico) - Universidade Federal de Juiz de Fora, Faculdade de Direito. Programa de Pos-Graduaçao em Direito, 2021.

1. Provas em video. 2. Dissertaçao de Mestrado. 3. Universidade Federal de Juiz de Fora - 4. Faculdade de Direito . 5. Mestrado. I. Riccio, Vicente, orient. II. Ttulo. 


\section{A PROVA EM VÍDEO NA JUSTIÇA DO TRABALHO: UM ESTUDO DE CASO COMPARATIVO}

Dissertação apresentada ao Programa de Pós-graduação em Direito e Inovação da Universidade Federal de Juiz de Fora como requisito parcial para a obtenção do grau de Mestre na área de concentração Direito, Argumentação e Inovação sob orientação do Prof. Dr. Vicente Riccio submetida à Banca Examinadora composta pelos membros:

Aprovada em de de 2021.

\section{BANCA EXAMINADORA}

Orientador: Prof. Dr. Vicente Riccio.

Universidade Federal de Juiz de Fora

Profa. Dra. Clarissa Diniz Guedes.

Universidade Federal de Juiz de Fora

Prof. Dr. Marcelo de Castro Cunha Filho. 


\section{AGRADECIMENTOS}

Ao Gabriel, Miguel e Denise, minha família, maior riqueza concedida por Deus, pelo apoio, compreensão e carinho. Ao Professor Vicente por toda a ajuda e valiosos ensinamentos. A Deus e aos espíritos de luz que me guiaram para a aprovação. 


\title{
A PROVA EM VÍDEO NA JUSTIÇA DO TRABALHO: UM ESTUDO COMPARATIVO
}

\author{
Eduardo Atalla Barletta
}

\begin{abstract}
RESUMO
O presente estudo tem como objetivo principal responder às seguintes indagações: A Justiça do Trabalho Brasileira necessita de preparo para enfrentar vídeo como meio de prova? Em que medida os operadores do direito, atuando na justiça do trabalho, apresentam habilidade e eficiência para lidar com a prova em vídeo em seu trabalho cotidiano? Há necessidade de alfabetização visual dos operadores de tal ramo jurídico pátrio? Para tanto, buscou-se fazer a análise, em estado gradativo, de profundidade, acerca de três casos concretos que tramitaram na Justiça do Trabalho do Rio de Janeiro: inadmissão da prova em vídeo, decisão de segundo grau sem reforma e com mera referência, decisão reformada em segundo grau. Inicialmente, realizou-se a revisão de literatura sobre o tema. Após, através do método qualitativo do estudo de caso concreto em profundidade, investigaram-se a forma e conteúdo de admissão e fundamentação das decisões com base na prova em vídeo. Observou-se o tratamento dado à prova em vídeo desde a recepção dos dados em formato digital, as dificuldades e, ou resistências para a visualização das imagens, a efetiva visualização da prova pelo julgador e a valoração utilizada na fundamentação. Assim, foi possível averiguar a aptidão dos operadores do direito envolvidos em lidar com a prova em formato audiovisual. Por fim, a dissertação sugere a construção de política voltada à alfabetização digital dos profissionais em direito, desde o processo básico de formação nas faculdades de direito à formação e continuidade em suas carreiras.
\end{abstract}

Palavras-chave: provas em vídeo, alfabetização visual, justiça do trabalho, estudo de caso. 


\title{
A PROVA EM VÍDEO NA JUSTIÇA DO TRABALHO: UM ESTUdO COMPARATIVO
}

Eduardo Atalla Barletta

\begin{abstract}
The main objective of this study is to answer the following questions: Is the Brazilian Labor Court prepared to face video as a means of evidence? To what extent do legal professionals working in the labor court have competence to deal with video evidence in their daily work? For this purpose, we sought to carry out the analysis, in a gradual, in-depth state, of three specific cases that were processed in the Labor Court of Rio de Janeiro: inadmissibility of the video test, second degree decision without reform and with mere reference, decision reformed in the second degree. Initially, a literature review on the subject was carried out. Afterwards, through the qualitative method of in-depth concrete case study, the form and content of admission and reasoning for decisions based on the video test were investigated. The treatment given to the video test was observed, from the reception of the data in digital format, the difficulties and/or resistances for the visualization of the images, the effective visualization of the test by the judge and the valuation used in the grounds. Thus, it was possible to ascertain the aptitude of the legal operators involved in dealing with the evidence in audiovisual format. Finally, the dissertation suggests the construction of a policy aimed at the digital literacy of legal professionals, from the basic training process in law schools to training and continuity in their careers.
\end{abstract}

Keywords: video evidence, visual literacy, labor justice, case study. 


\section{SUMÁRIO}

1 Introdução.

2Pressupostos teóricos.

2.1 - Embasamento histórico

2.2 - Emoção X Razão, Direito X Mídia, Revolução digital

2.3 - Cultura jurídica, retórica e argumentação na relação Direito x Mídia - atualização e flexibilização de conceitos legais

2.4 - Leading Case Scott X Harris

2.5 - Iliberalismo Cognitivo, realismo ingênuo

2.6 - Testemunha ocular, testemunha silenciosa, janela pra realidade, objetividade ou imparcialidade do vídeo, mito do cinema total, interpretação cruzada do filme (cross examining) 3 - Metodologia - casos concretos em gradação.

4 - Arcabouço principiológico trabalhista e a prova em vídeo

5 - Casos concretos.

5.1 - Inadmissão da prova em vídeo.

5.2 - Decisão mantida em segundo grau de jurisdição.

5.3 - Decisão reformada em segundo grau de jurisdição

6 - Considerações finais

7 - Referências. 



\section{INTRODUÇÃO}

As histórias são contadas em formato digital na sociedade contemporânea. A tecnologia tem avançado de forma categórica e o Direito não tem conseguido acompanhar sua evolução. A extrema facilidade na gravação de imagens tem trazido aos processos judiciais trabalhistas modernos tipos de prova revelando-se verdadeiro desafio aos operadores do Direito.

Imagens de câmeras de segurança, filmagens de smartphones, gravações de filmes passados em tempo real (lives de instagram) e através de drones além de satélites são apenas alguns exemplos das inovações advindas da modernidade que se tornaram provas a serem analisadas no campo processual. O impacto da avalanche digital tem sido ainda mais expressivo na área trabalhista ante a forte incidência dos princípios da informalidade, celeridade e a natureza alimentar e emergencial do crédito trabalhista. Com isso, as provas produzidas em vídeo tornaram-se recorrentes no âmbito laboral, demandando do intérprete novas habilidades.

A modernização da produção das provas e sua compatibilidade ao Direito Processual Trabalhista revelam-se, portanto, de extrema importância para a sociedade atual. Originam-se daí as principais indagações objeto da presente pesquisa: a Justiça do Trabalho Brasileira necessita de preparo para enfrentar o vídeo como meio de prova? Em que medida os operadores do direito, atuando na justiça do trabalho, apresentam habilidade e eficiência para lidar com a prova em vídeo em seu cotidiano? Há necessidade de alfabetização visual dos operadores do direito de tal ramo jurídico pátrio?

A resposta a tais indagações encontra ressonância nos estudos realizados por Kahan (2009), Sherwin (2011) e Silbey (2008) os quais analisaram de forma apurada casos concretos norte-americanos em que foi utilizada a prova produzida em vídeo, concluindo pela necessidade de alfabetização visual dos operadores do Direito. Delimita-se assim o objetivo primordial do presente estudo. A análise de como a prova produzida em vídeo é tratada na seara trabalhista, analisando-se aspectos procedimentais e teóricos em alinho às indagações principais acima delineadas.

Para isso, procurou-se, em síntese, averiguar precipuamente sobre a aceitação da referida prova (grau de resistência e / ou recebimento, manuseio, dificuldades procedimentais e a efetiva visualização das imagens), e acerca do grau de sua influência na resolução das lides trabalhistas brasileiras (em sede de primeiro e segundo grau de jurisdição), cotejando princípios e institutos processuais cíveis, constitucionais e trabalhistas à sociologia jurídica, com embasamento principal em artigos da literatura internacional. A investigação se deu principalmente através do estudo qualitativo de casos concretos oriundos do Tribunal Regional do Trabalho da Primeira Região em grau de profundidade da análise da prova produzida em 
vídeo: (1) inadmissão da prova em vídeo; (2) decisão de mérito de segundo grau, sem reforma, na qual houve apenas menção ao ato de assistir o vídeo pelo primeiro grau de jurisdição; (3) completa análise da prova em vídeo em primeiro e segundo graus de jurisdição com reforma da decisão em sede recursal.

À organização desse trabalho optou-se por sua divisão em capítulos. O primeiro deles corresponde à presente introdução. No capítulo 2 são estudados os fundamentos históricos e os pressupostos teóricos, sendo realizada a revisão da literatura sobre o tema, ali tendo sido destacado acerca das consequências da revolução tecnológica digital no mundo do Direito; as principais diferenças entre a mídia e o Direito; o leading case Scott x Harris e os mitos surgidos nos estudos em referência; a flexibilização de conceitos legais e a necessidade de alfabetização visual.

No capítulo 3 é esclarecida a metodologia abordada para a garantia da cientificidade do estudo, ali sendo justificada a escolha da pesquisa qualitativa de caso em profundidade, tal como ensinado por Epstein e King (2019) Yin (2015, 2016). A opção pelo método qualitativo de estudo de caso concreto, em profundidade, encontra ressonância na doutrina de Yin (2015, 2016) e Epstein e King (2019) os quais elucidam com clareza sobre a consistência e cientificidade das conclusões elaboradas com base nessa metodologia.

O capítulo 4 corresponde ao estudo dos casos concretos em profundidade e gradação em comparação aos nortes teóricos traçados, conforme acima destacado. No quinto capítulo estão presentes as considerações finais onde é realizada uma abordagem sintética de todo o conteúdo com caráter propositivo preponderante de resposta efetiva às indagações objeto da pesquisa. 


\section{2 - PRESSUPOSTOS TEÓRICOS:}

\subsection{Embasamento histórico:}

A imagem é utilizada como representação da realidade no intuito de demonstrar o ponto de vista de certa pessoa ou setor da sociedade, desde tempos remotos, antes mesmo do surgimento do Estado Moderno. Nas cidades-estado já eram utilizadas imagens para atrair a atenção dos cidadãos, no objetivo de influenciá-los ou convencê-los em direção ao interesse estatal. Dessa forma, a utilização da imagem para o convencimento de outrem remonta à origem dos emblemas, figuras representativas de certo fato às quais teriam o poder de influenciar a mente das pessoas.

Também na Roma antiga era comum o uso de brasões da nobreza, imagens e símbolos arquitetônicos sempre no objetivo de evidenciar a militarização e o poder, o que deu início ao que chamamos de teoria do emblema legal. Doutrina legal moderna a qual tem por objeto a definição, interpretação e uso de imagens, na qual se ressalta que, desde a antiguidade, imagens e estátuas eram utilizadas para transmitir autoridade à norma soberana (GOODRICH, 2014) o que vai ao encontro do mecanismo único de legitimação de poder da sociedade ocidental, uma estrutura antropológica dispositiva sobre o qual se baseia o conceito de poder e de direito, a dimensão do Terceiro - Tiers - (HEIRITIER, 2014).

Deriva daí o conceito de emblemas seculares os quais podem ser observados num paralelo comparativo entre o Império Romano e a globalização, exercendo uma função dogmática e estética de figuras representativas como o Papa, o Dalai Lama, os presidentes ou as rainhas, bem como a Coca-cola, Nutella ou os campeões do esporte. Ou seja, as imagens atuam diretamente na legitimação do poder constituído e seu regramento. Tal se dá porque a visualização de uma imagem, a qual passa a ser construída internamente, forma o pivô entre o conteúdo de significado de uma regra legal, um objeto de pensamento e o comportamento de acordo com a regra a qual expressa uma mensagem que passa a ser pensada como real (SCHOOTEN, 2014).

Emerge daí que regras jurídicas não são objetos materiais, mas objetos do pensamento os quais projetam imagens que, por sua vez, exercem pressão para serem socialmente concretizadas. Logo, a imagem apresenta forte carga representativa e normativa, sendo utilizada, de forma secular, para induzir, coibir ou demonstrar algo no interesse de alguém (HERITIER, 2014). A imagem, portanto, exerce autoridade, o que se pode observar do emblema representativo do Estado, no qual o rei com a coroa, a espada e o cetro, nas mãos, demonstra a soberania estatal centralizada em sua pessoa. 


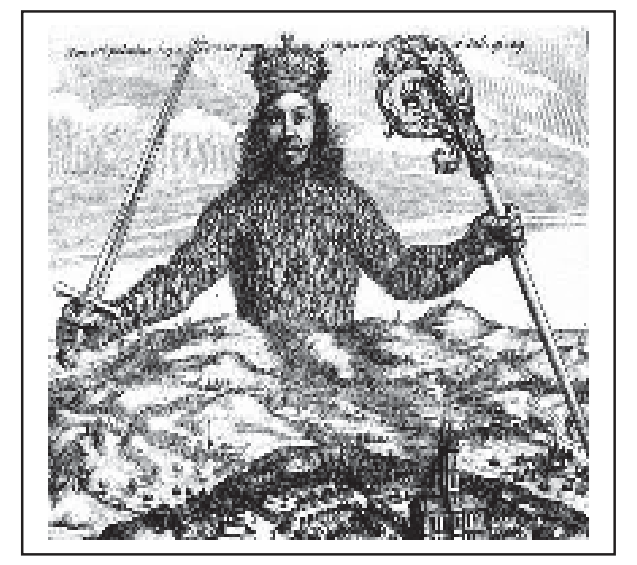

A utilização persuasiva da imagem como objeto de autoridade e poder, através de figuras emblemáticas, sobrevive, assim, por séculos, também podendo ser observada, na sociedade contemporânea, como, por exemplo, através do emblema estatal norte-americano do Tio Sam o qual transmite a ideia de militarização e poder trazendo forte carga de convencimento das pessoas a se alistarem ao exército americano, evidenciando o apelo ao sentimento do patriotismo americano com objetivos políticos específicos.

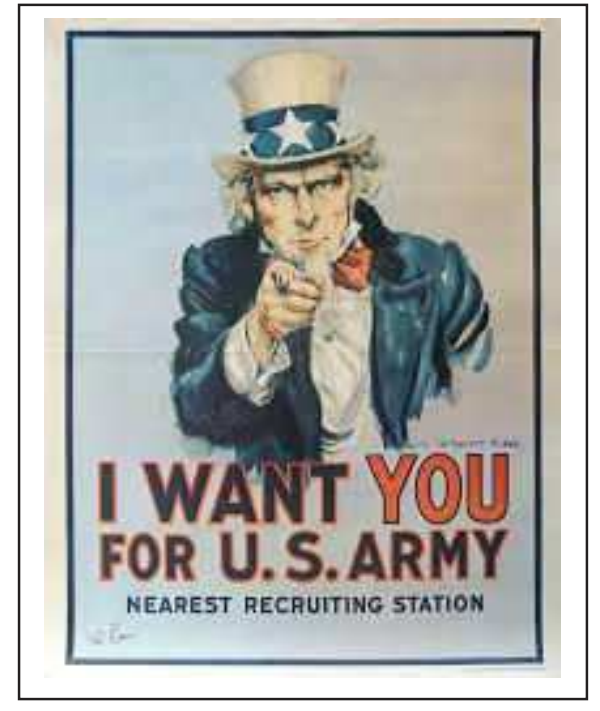

Denota-se daí, portanto, que a tradição de emblemas legais chegou ao palco social como um romântico aparelho para a promulgação e difusão da ideia de Direito, poder, autoridade e normatividade representado pela capacidade da imagem de transportar e aplicar a regra abstrata de uma forma diferente que a simples expressão positiva jamais alcançaria (GOODRICH, 2014). Essa romântica forma de se transmitir autoridade ultrapassou séculos encontrando campo fértil para sua utilização na sociedade moderna com a revolução tecnológica, o que tem se acentuado com o choque de realidades advindo da relação íntima entre a mídia e o direito, trazendo novos desafios aos educadores e operadores do Direito e demandando estudos e pesquisas sobre o tema, como veremos a seguir.

\subsection{Direito x mídia, razão versus emoção, revolução tecnológica:}


A sociedade contemporânea tem sido marcada pela revolução da tecnologia digital o que tem acarretado profundas transformações nas práticas comerciais, políticas, econômicas e de comunicação (SHERWIN, 2019). O processo de globalização aproximou os indivíduos através da tecnologia, o que foi a causa da propagação do audiovisual em todas as sociedades ao redor do mundo tornando os meios de comunicação imprescindíveis para o desenvolvimento social (BAUMANN, 1999). E, nesse emaranhado de meios de comunicação, se inserem inúmeras culturas mescladas em uma mesma sociedade, em razão do constante dinamismo dos grupos sociais, todos atingidos pela revolução tecnológica da última década (DA MATTA, 1987).

A internet modificou o sistema bancário, aplicativos de celular passaram a ser mais utilizados que as próprias instancias físicas das agências, novas formas de pagamento surgiram como o recentíssimo PIX; os livros de papel têm sido paulatinamente substituídos pelos famosos e-books e os respectivos aparelhos de leitura digital como os tablets e o kindle, o que também aconteceu com jornais e revistas, atualmente comercializados na forma digital. As músicas passaram a ser comercializadas através de plataformas específicas e em aplicativos de celulares, como o spotify, o deezer, entre outros, transformando os cds em ultrapassados e obsoletos; os dvds foram substituídos por plataformas de filmes e redes sociais como o netflix e o youtube.

O comércio passou a ser amplamente realizado através das plataformas digitais, surgindo novas formas de vendas de produtos através de aplicativos de celulares, como o mercado livre. O marketing empresarial passou a ser amplamente realizado no youtube e instagram, sempre com predominância de estratégias visuais e imagéticas; os aparelhos de celulares se transformaram em smartphones e foram amplamente modernizados, sendo alçados ao status de objetos mais cobiçados da década, sempre com suas câmeras cada vez mais modernas e com a possibilidade de realização de inúmeras tarefas através de diversos aplicativos. Entramos, de fato, em uma era visual e digital (SHERWIN, FEIGENSON e SPIESEL, 2005) com a inserção de novas tecnologias em todas as áreas demandando a aquisição de conhecimentos em todos os setores da sociedade (PORTER, 2013). Abaixo podemos observar alguns símbolos dos principais aplicativos atualmente utilizados, onde podemos perceber o apelo visual das marcas, típico da era tecnológica ora vivenciada. 


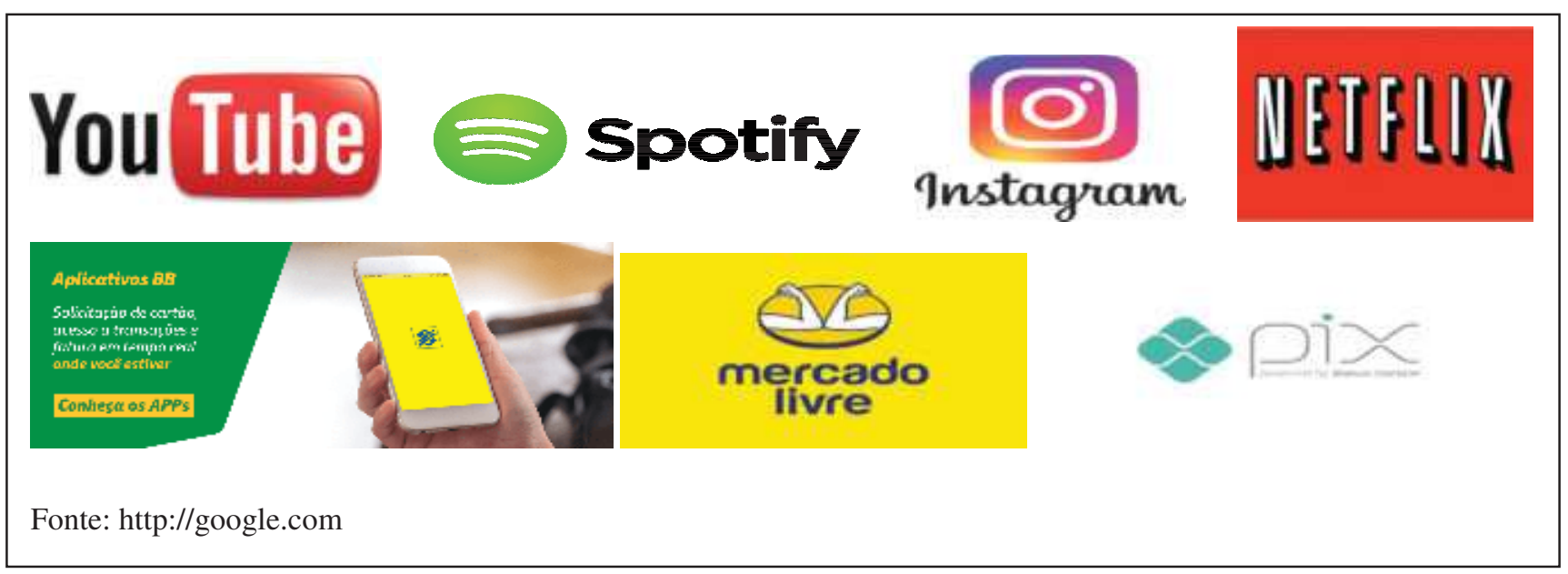

Assim, verificamos que a tecnologia radicalizou diversas atividades, ganhando destaque, nesse cenário, a inigualável facilidade de produção de imagens, a qual ora vivenciamos, com a propagação de câmeras ao redor do mundo. Parecemos viver em um verdadeiro big brother onde tudo e todos estão sendo filmados constantemente em um mundo impregnado pelo imagético onde câmeras se espalham por todos os cantos. Câmeras nos celulares, nas vias públicas, em sinais de trânsito, nas portarias dos prédios, nos painéis de táxis e ubers, dentro dos ônibus, nas empresas, que hoje são dotadas de sistemas de vigilância amplamente estabelecidos, nos capacetes de esportistas radicais e esportes aquáticos (resistentes ao sol, água e impactos como as câmeras "go pro" e "pro hero"), nos campos de futebol, nas viaturas policiais (dash cams) e até mesmo câmeras voando através de drones e acopladas em aviões e satélites, no espaço, com poderes de mapeamento global através de produção de imagens outrora jamais imaginados.

Paralelamente a essa facilidade de produção imagética, os meios de comunicação multiplicaram-se, trazendo amplas possibilidades de transmissão de imagens e áudio, através de inúmeras plataformas, como se observa, por exemplo, dos aplicativos google meet e das lives de instagram onde reuniões virtuais e aulas on line atualmente podem ser realizadas à distância. Com isso, os tradicionais meios de comunicação em massa, como a televisão e o rádio, ganharam fortes concorrentes em algo que anteriormente lhes era exclusivo, uma vez que a divulgação de vídeos para o grande público tornou-se algo facilmente realizável por qualquer pessoa revolucionando a transmissão de gravações em larga escala. Atualmente qualquer indivíduo minimamente antenado com os aplicativos de celulares encontra-se habilitado a gravar e publicar vídeos para pessoas em qualquer lugar do planeta, através de simples canais no youtube, não havendo limites para gravação e transmissão de imagens, inclusive em tempo real. 
Assim, à medida da facilidade de utilização de tais meios de comunicação observamos uma transformação da sociedade de mera expectadora para produtora paralela e consumidora de mídia, (GOLDSMITH, 2010), o que pode ser exemplificado pelo surgimento do novo ramo profissional intitulado influencer digital, o qual se baseia na divulgação diária de vídeos no intuito de persuadir o indivíduo a certos pontos de vista, inclusive políticos e comerciais. A sociedade tornou-se, dessa forma, mais complexa e sofisticada, o que não tem sido diferente para o campo do Direito. O processo judicial transformou-se em eletrônico; os antigos processos de papel têm sido gradativamente digitalizados passando a ter tramitação obrigatória em formato digital; as audiências processuais têm sido paulatinamente substituídas pela forma virtual e à distância e o atendimento aos advogados e cidadãos tem sido realizado através do novo sistema de balcão virtual.

Ademais, diversas atividades têm sido realizadas através da inteligência artificial recentemente instituída e regulamentada pelo Conselho Nacional de Justiça onde se procedeu à criação de robôs, como por exemplo Victor, Luzia, Clara, Jerimum e Poti (Portaria CNJ 271/2020) 1. O robô Poti encontra-se atualmente exercendo a atividade automática de penhora online de valores em contas bancárias de devedores, Clara e Jerimum estão em fase de testes e provavelmente terão as atribuições de categorizar e rotular processos, ler documentos, recomendar tarefas e sugerir decisões às quais, todavia, serão anexadas como padrão, mas analisadas por um funcionário.

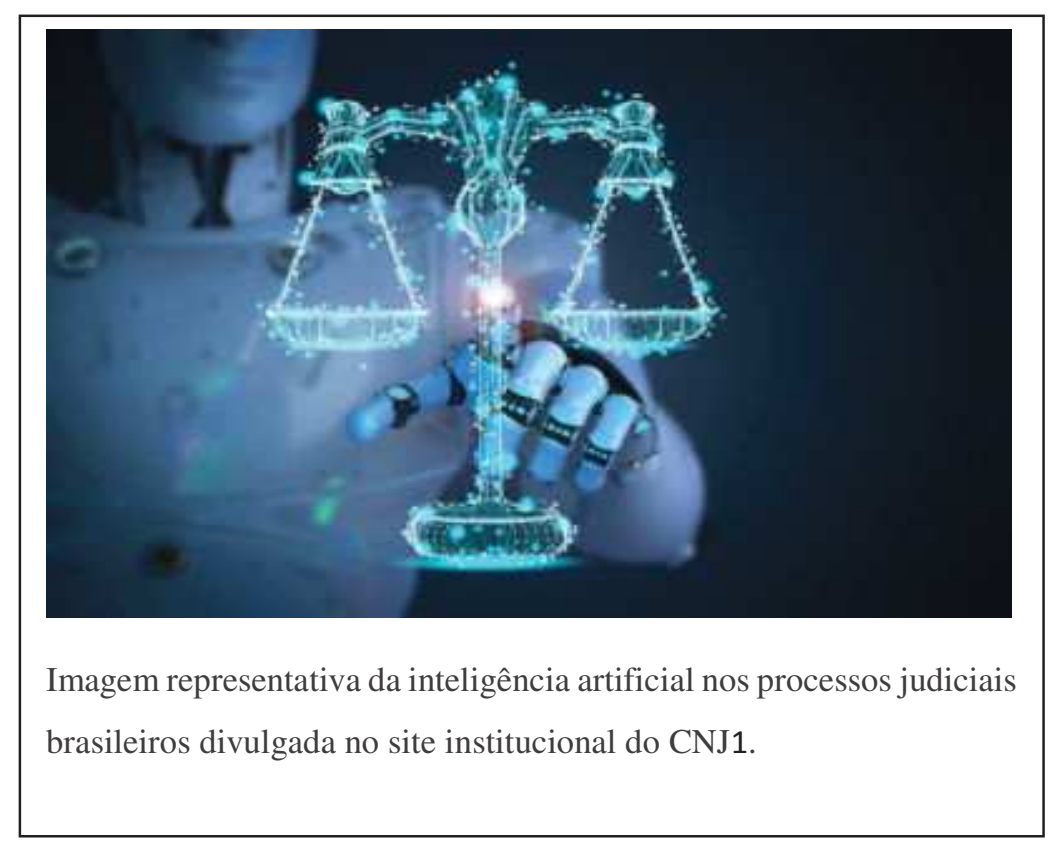

\footnotetext{
${ }^{1}$ Disponível em https://atos.cnj.jus.br/atos/detalhar/3613
} 
As mudanças advindas do avanço tecnológico têm impactado não somente o campo logístico e instrumental, mas principalmente a área processual propriamente dita. A velocidade com a qual se tornou possível o registro digital de fatos fez com que novos tipos de prova desaguassem de forma desproporcional ao campo processual, tornando-se habitual a incidência de provas em vídeo nos tribunais. A mídia invadiu repentina e inadvertidamente o campo do Direito fazendo sobressair um verdadeiro choque de realidades, fruto do contraste entre sua própria origem e a transformação contemporânea da sociedade. Dessa forma, as dificuldades atualmente vivenciadas pelo intérprete na análise dos novos tipos de prova possuem elo direto com as diferenças essenciais entre o Direito e a Mídia.

A própria origem do Direito Brasileiro já demonstra de forma clara a relação paradoxal entre tais institutos. Isso porque o Direito Brasileiro é oriundo da clássica tradição Romano Germânica, a qual predomina, historicamente, o uso da palavra escrita, além de ter como pressuposto de validade da fundamentação das decisões a objetividade da argumentação e a racionalidade (ALEXY, 2015). Assim, o Direito brasileiro tem se pautado, desde seu nascimento, pelo uso de mecanismos racionais em rígido formalismo, como o comparecimento das partes e advogados às instâncias físicas dos monumentais palácios da Justiça, o tempo específico de fala nas audiências presenciais e a rigidez das formas de manifestação estabelecidas nos clássicos códigos escritos e no contraditório formal (RICCIO, et al 2016).

Podemos observar, portanto, que o costume do Direito é arraigado ao trâmite formal do processo e ao uso estrito da razão para a prática processual. Todas essas características contrapõem-se à mídia, a qual tem sua origem na recente revolução tecnológica, sendo dotada de caracteres extremamente contemporâneos. Fluidez, fragmentação e capilaridade de exposição de imagens, informalidade, instantaneidade e ausência de tempo específico de fala, além de nítido caráter indeterminado e oral demonstram que, de fato, há um verdadeiro choque de realidades (RICCIO, et al 2016).

Para além de todas essas características paradoxais, a mídia apresenta traço determinante que altera a lógica racional escrita do Direito, despontando como uma das principais diferenças entre tais institutos, qual seja, a faceta emocional da imagem. As emoções diante de um estímulo visual provocam reações ativadas pelo cérebro que, por sua vez, acionam todo o conjunto psicológico, cultural e cognitivo do ser humano o que torna as impressões em relação a tais evidências imprevisíveis, gerando desconfiança e incerteza (SHERWIN, 2011). Por isso as reações diante de evidências não interativas, como a simples leitura de um texto escrito, tendem a ser diferentes em relação ao ato de assistir a um vídeo sobre o registro de um fato, pois a interatividade das evidências visuais traz imprevisibilidade acerca de sua 
interpretação (FEIGENSON apud TAIT, 2007). Emerge daí o conflito razão versus emoção, o que tem gerado resistência na absorção do imagético ao campo processual.

Qual seria a reação imediata do intérprete ao analisar uma prova produzida em vídeo na qual o trabalhador aparece se masturbando em pleno local de trabalho? Será que o fator emocional influenciaria na racionalidade da decisão? ${ }^{2}$ Parece-nos não haver dúvida acerca da influência da emoção na tomada da decisão sobre evidências visuais. Ora, imagens, mais que palavras, transmitem significado através de lógica associativa que opera em grande parte subconscientemente, especialmente através de seu apelo emocional, sendo o visual impregnado e fortalecido pela emoção. Tais associações afetivas podem ser tão intensas ao ponto de incontroláveis, incidindo na análise dos fatos de forma subliminar ou inconsciente, sem que o intérprete perceba (SHERWIN, 2019). O modo de abordagem dos elementos imagéticos deve ser, portanto, substancialmente diferente dos métodos interpretativos textuais, pois a imagem colide frontalmente com o discurso racionalista tradicional do Direito, fragilizando-o ao não impor uma separação dicotômica entre razão e emoção e possibilitar a influência de meios não racionais - os sentimentos - na tomada de decisão (RICCIO, et al. 2016).

Essa relação paradoxal tem se tornado cada vez mais intensa na sociedade contemporânea, ante a atual atmosfera barroca digital, onde observamos a profusão descontrolada de imagens emocionalmente poderosas, às quais podem carregar diversos significados. Essa diversidade de elementos visuais e possíveis interpretações acaba por revelar uma certa faceta desagregadora da imagem o que desagua na desconfiança e resistência em sua inserção ao mundo processual (SHERWIN, 2011). Todo esse cenário evidencia a dicotomia "razão versus emoção" e a necessidade de se equilibrar a disparidade entre um mundo em que, desde sua origem, há a prevalência da razão para que se atinja um patamar de decisão justa (ALEXY, 2015) e outro em que há nítida influência do caráter emocional (SHERWIN, 2011), o que outrora sequer poderia ser aventado. Esse desequilíbrio o qual parece ser meramente conceitual tem consequências práticas decisivas em uma batalha judicial, onde o poder de convencimento torna-se fator importantíssimo para a influência da decisão e, nesse aspecto, a parte que se valer de provas em vídeo pode alcançar posição de vantagem pelo fortalecimento no campo probatório, pois o poder persuasivo das imagens, derivado do fator emocional é, indubitavelmente, um considerável diferencial (SOUZA, 2016).

\footnotetext{
${ }^{2}$ Decisão do magistrado então titular da Vara do Trabalho de Angra dos Reis, processo n. 010201478.2017.5.01.0401.
} 
Todavia, a despeito das diversas diferenças e contraposições, Direito e Mídia possuem pontos de convergência. Ambos são institutos centrais no arranjo social contemporâneo ao utilizarem o discurso para estabelecer ações sociais em torno de questões práticas e problemáticas como corretas e aceitáveis, influenciando nas teses acerca de padrões comportamentais (RICCIO et al., 2016). Os dois institutos contribuem para a formação de um tipo específico de moralidade na sociedade, eis que suas atividades reforçam ou refutam padrões morais a serem seguidos pelos indivíduos. Ambos demandam objetividade e imparcialidade para o exercício de suas atividades, preço exigido para a aquisição da credibilidade perante as instituições sociais e a população como um todo. O Direito exerce o poder estatal de tomada de decisões, o poder simbólico da mídia procede à cobrança das decisões; ambos operam decisões de modo prático com o poder de mudar a opinião pública e as instituições através do discurso.

Não há dúvida, portanto, que tais institutos têm profundo papel de relevo na sociedade e necessitam compatibilizar-se, o que tem demandado a atualização de conceitos legais e doutrinários clássicos, conforme veremos a seguir.

\subsection{Cultura jurídica, retórica e argumentação na relação Direito x Mídia - atualização e flexibilização de conceitos legais.}

As constantes inovações decorrentes da tecnologia não acarretam apenas consequências puramente técnicas devendo ser analisadas principalmente sob a ótica epistemológica e sócio cultural (MESSIAS DA SILVA, 2018), o que não deve ser diferente com a inserção das provas imagéticas ao campo processual. Assim, a invasão da mídia ao mundo jurídico tem gerado discussões acerca da legalidade da aplicação das inovações advindas da tecnologia e de institutos contemporâneos, desaguando na necessidade de flexibilização e atualização de clássicos conceitos legais e doutrinários. Isso tem ocorrido na justiça norte-americana, onde se tem debatido sobre a possibilidade da oitiva de testemunha através de um sistema de câmera bidirecional, na qual se torna possível o contato visual desta com o réu, em tempo real (AGUIÑAGA, 2014). Todavia, o uso de tal ferramenta esbarraria na cláusula americana de confronto, segundo a qual o réu teria direito ao confronto físico com a testemunha, surgindo a discussão se seria possível sua aplicação em uma aproximação análoga, como no vídeo em bidirecional. A maioria dos autores norte-americanos têm defendido sua utilização argumentando ser inevitável a reformulação tecnológica dos tribunais e da sala de audiências ante a revolução tecnológica e as constantes inovações daí advindas, o que justificaria a flexibilização da Cláusula de confronto (AGUIÑAGA, 2014).

A questão da aplicabilidade do testemunho em vídeo bidirecional gerou incerteza perante a comunidade jurídica e trouxe à tona questões importantes a serem debatidas, fruto da 
invasão tecnológica em uma geração intitulada por alguns autores de "face time generation" (AGUIÑAGA, 2014). Discussão parecida tem ocorrido no Brasil, onde a oitiva de testemunhas em presídios tem sido paulatinamente adotada pela justiça no objetivo de se proceder à economia de recursos públicos com o deslocamento e evitar fugas, assegurando maior segurança pública. Percebe-se assim que a nova realidade da realização de audiências virtuais tem desafiado os operadores do Direito a atualizar o conceito legal de contato físico com a testemunha, adequação a qual também tem se mostrado extremamente necessária em relação ao conceito de cultura jurídica.

Isso porque a doutrina tradicional tem delimitado o conceito de cultura jurídica sob uma perspectiva fechada, centrada apenas no direito formal e na relação dos indivíduos para com a lei instituída, excluindo de seu campo conceitual as inovações ocorridas nos últimos anos. Cultura jurídica teriam assim, um único conceito clássico, levando-se em consideração apenas os aspectos formais da técnica jurídica, vocabulário, conceitos, institutos e interpretações empregadas historicamente pelos operadores do direito (RICCIO, 2001). Logo, segundo esse conceito estanque a cultura jurídica seria, única e exclusivamente, formada pelos conhecedores do conhecimento técnico do direito e de seu complexo e intrincado regramento normativo (RICCIO, 2001).

Entretanto, na última década, a mídia passou a ser palco de ampla diversidade de discursos jurídicos em que o justo e o legal passaram a ser tema, trazendo à tona concepções populares de justiça - ou folk knowledge - às quais passaram a exercer influência sobre as decisões judiciais, desaguando diretamente no mundo do Direito e na cultura jurídica, demandando sua flexibilização conceitual (RICCIO, 2001). Oriundo da íntima relação entre mídia e Direito, o folk knowledge seria o senso comum, a compreensão diária, dada como certa, a qual molda a percepção, o pensamento, as ações e reações dos indivíduos a eventos e situações, ou seja, o Direito construído com base na vida cotidiana, mediante interações dos indivíduos com o Direito oficial. A ideia do justo passou a não ser exclusividade dos tribunais, subsistindo em um conjunto de imagens e percepções exteriores ao mundo jurídico formal e à lógica dos operadores do direito.

As categorias folk passaram, dessa forma, a ter influência sobre o Direito oficial - ora o direcionando, ora o coordenando ou até mesmo o apoiando - postulando sua integração ao conceito de cultura jurídica e, consequentemente, a atualização e flexibilização deste. Assim, a possibilidade da construção do Direito com base nas concepções populares passou a se contrapor à linha oficialista e tradicional segundo a qual a mídia teria apenas o papel de usurpadora da função do Direito, deixando ainda mais em evidência a necessidade de alteração 
conceitual. Tomemos como exemplo o crime de tortura, cuja tipificação legal no Brasil ocorreu somente após o Jornal Nacional passar imagens de diversas manifestações populares à época, ou seja, as concepções populares de justiça contribuíram expressivamente para a reconstrução do Direito oficial. Portanto, o folk knowledge é uma ferramenta apropriada para a averiguação do mundo contraditório de elementos e instituições existentes no exterior do sistema jurídico formal, moldando-o, devendo fazer parte da cultura jurídica (RICCIO, 2001).

Nessa linha de raciocínio, após estudos sobre casos concretos, grande parte da literatura americana passou a defender que a exposição na mídia dos fatos postos em julgamento, tendem a moldar o limiar da dúvida razoável e o entendimento do júri, influenciando-os diretamente (TYLER, 2006). Nítido se torna, assim, o poder de influência das concepções populares do justo no cenário jurídico atual numa era digital onde se possibilita julgamentos morais sobre eventos acontecidos em lugares e tempos diferentes, dando ainda mais amplitude aos elementos folk (RICCIO, 2018).

Em outras palavras, os aspectos simbólicos de justiça, concebidos pela sociedade e manifestados em meios mediáticos, devem fazer parte do conceito de cultural jurídica, o qual merece ser atualizado. Não somente o que é escrito e racionalizado faz parte dessa cultura, mas também o Direito exterior ao sistema jurídico propriamente dito. Os reality shows, a ficção televisada, os programas voltados para a crítica sobre crimes ocorridos, tudo isso deixa visível a participação do justo na vida cotidiana refletida na mídia, o que se insere de variadas formas no mundo do Direito. Por exemplo, o Ministério Público do Rio de Janeiro já processou dois participantes do reality Big Brother Brasil por racismo, na mesma via da relação íntima entre Direito e Mídia em que jurados americanos passaram a desconsiderar provas apresentadas que não se incluíam no padrão do famoso seriado CSI o que gerou o polêmico efeito CSI (TYLER, 2006).

Os filmes também participam dessa construção do folk, pois se revelam como meio cultural no qual fatos sociais relevantes são retratados e discutidos, desempenhando um papel de relevo na formação de nossas percepções e ideias. As narrativas de justiça que surgem em alguns filmes retratam temas generalizados inerentes às representações da justiça transmitindo significados e mensagens ideológicas que acabam por moldar as crenças tidas pelos indivíduos como certas acerca do justo. Assim, a mídia atualmente observada reflete inúmeras plataformas nas quais a realidade social não é apenas meramente retratada, mas negociada e desenvolvida, não se podendo subestimar seu papel de influência nas percepções e entendimentos públicos sobre justiça (WELSH et al, 2011). 
Logo, a judicialização das relações sociais deve, de fato, comportar os elementos simbólicos imagéticos da justiça - folks - pois esses revelam dinamismo e criatividade em íntima relação com o Direito, atuando na construção do Direito oficial. Uma vez que as concepções populares de justiça são legítimas e possuem papel determinante na formação do sistema jurídico, passa a ser necessária a ampliação da perspectiva conceitual de cultura jurídica no intuito de se abranger a lógica de justiça externa à dos operadores do Direito. Como acima ressaltado, o apego ao formalismo, à palavra escrita e ao tecnicismo dos operadores do direito refletiram no conceito tradicional de cultura jurídica, característica essa que também observamos no conceito clássico de argumentação jurídica.

A nova intensidade da relação Direito versus Mídia, experimentada pela extrema facilidade na produção de imagens e produção de provas em vídeo, tem desafiado o sistema Romano-Germânico que lhe deu origem. Deriva daí que a mesma atualização e flexibilidade necessária para o conceito de cultura jurídica mostra-se emergente no campo da argumentação jurídica. O sistema argumentativo das provas baseadas na nova lógica do instantâneo e do visual se contrapõe ao modelo tradicional de argumentação jurídica, uma vez que a ubiquidade da imagem rompe com a cultura jurídica clássica e seu apego à palavra escrita. A argumentação jurídica passa a ter novo elemento, a argumentação visual, a qual possui características diferentes do modelo clássico de argumentação verbal (SALGADO, 2019).

A cultura jurídica brasileira, e aqui nos referimos ao conceito formalista tradicional, arraigado e intensamente influenciado pela lógica escrita, se mostra incompatível com o procedimento argumentativo necessário para o correto enfrentamento das novas provas imagéticas. O que se observa atualmente é que até mesmo a discussão do conteúdo de provas em vídeo é realizado de maneira textual, o que merece ser superado (SALGADO, 2019). A argumentação jurídica, outrora classicamente aplicada, não mais se sustentará, tendo em vista que a construção e desconstrução de argumentos visuais demandam métodos diferentes e inovadores, com a compreensão de símbolos visuais, o que vai muito além da simples visão da lei escrita e do modelo clássico de argumentação verbal, o qual se revela insuficiente diante da contemporânea avalanche imagética (SALGADO, 2019).

A percepção audiovisual e sua correta interpretação perpassam pelo reconhecimento e análise dos elementos multimodais da imagem o que vai de encontro aos atuais sistemas argumentativos utilizados nos processos, impregnados por métodos exclusivamente textuais e verbais, desconhecedores do caractere visual. Problemas com a hermenêutica da imagem são agravados, profundamente, por sua integração com sons, imagens e outras evidências visuais (EDMOND, 2013), o que demonstra a extrema urgência de atualização nos métodos 
interpretativos e argumentativos atualmente utilizados. $O$ que as imagens são, como são percebidas e interpretadas e seu grande potencial de propagação são premissas básicas que devem nortear o estudo do argumento visual (SPIESEL et. al, 2018) e a elaboração de uma nova teoria geral da argumentação.

Apesar de ainda não ser possível afirmarmos cabalmente a existência dessa nova teoria geral, propriamente dita, aspectos básicos de argumentação visual já se encontram sedimentados e começam a ganhar certo status de consolidação conceitual aos estudos. Assim, já se reconhece que a imagem é uma poderosa ferramenta de argumentação e evidência, a qual possui papel de grande relevo na construção de um raciocínio específico, podendo apresentar caracteres de afirmação ou justificação e não apenas funcionando como elemento probatório descritivo (RICCIO et al. 2018). Diante desses avanços a literatura começa a reconhecer que a retórica visual é veloz, eficiente, construtiva e persuasiva, sendo dotada de inúmeros dispositivos retóricos para orientar um discurso na construção de significado visual (MURRAY, 2015).

A argumentação jurídica deve abrir espaço para novos tipos de argumentos visuais e não-verbais, dando-se ênfase na tentativa de desenvolver a compreensão de diferentes formas de argumentação e seus desdobramentos, trazendo à tona uma verdadeira teoria de argumento multimodal (KJELDSEN, 2015) na qual se abre a possibilidade de o argumento manifestar-se através de múltiplas formas e não tão somente através da via verbal (SALGADO, 2019). Não apenas elementos ou modos verbais podem ser utilizados argumentativamente, mas também cheiros, sabor, sons ou toques (KJELDSEN, 2015). A lógica impregnada pelo escrito e pelo verbal precisa ser suplantada para se instituir nova ordem retórico-argumentativa, deixando-se para trás a ideia arcaica de que as imagens não podem ser classificadas como argumento.

Ao contrário do praticado pela cultura jurídica tradicional, argumentos não se limitam, única e exclusivamente, ao uso explícito de palavras; a argumentação é um processo cognitivo, não sendo essencial sua transmissão ou reconstrução verbal (KJELDSEN, 2015). E, de fato, observa-se atualmente um acordo geral no sentido de que os recursos visuais e o conteúdo imagético podem desempenhar importantíssimo papel na argumentação, o que deve ser ainda mais alvo de aprofundamento e consolidação com a formação de uma nova teoria geral da argumentação, com a inserção dos novos aspectos imagéticos e argumentos multimodais, como observados dentro do novo conceito de cultura jurídica, não formalista e mais abrangente, em alinho aos conhecimentos folk.

Gradativamente, a ciência jurídica vai dando contorno à nova retórica argumentativa visual, desenvolvendo conceitos e traçando as habilidades necessárias para a compreensão 
adequada da nova realidade imagética (RICCIO et al. 2018). Tal tarefa não deverá ser fácil, uma vez que dificuldades em lidar com dimensão retórica aguçada da imagem tem trazido resistência em sua absorção ao campo processual, fruto da contraposição das inovações ao sistema formalista racional da cultura jurídica brasileira. Torna-se necessário, portanto, realizar, incansavelmente, a transição entre a retórica baseada no texto escrito para a sensibilidade digital, o que demandará, de fato, a flexibilização conceitual de diversos institutos, tais como a cultura jurídica e argumentação jurídica (RICCIO et al. 2018).

Realizadas as digressões conceituais necessárias, passaremos a analisar o leading case norte-americano, Scott $x$ Harris, de onde se originaram as principais teorias e mitos sobre a imagem, o que será destacado por nós nas próximas considerações.

\subsection{A origem dos estudos: Leading case Scott X Harris:}

As discussões sobre alfabetização visual e as consequências da inserção das provas imagéticas no ramo jurídico apresentam-se nos estudos realizados por Kahan (2009), Sherwin (2011) e Silbey (2008), sobre o leading case norte americano, "Scott X Harris", no qual a prova em vídeo foi apreciada desde o primeiro grau de jurisdição até a suprema corte americana. Kahan (2009) e seus correligionários descreveram detidamente os fatos gravados. O caso é objeto de grande discussão na literatura sobre o uso do vídeo nas cortes americanas.

Em síntese, a decisão refere-se a perseguição policial ocorrida pouco antes das onze da noite, do dia 29 de março de 2001, em uma rodovia de duas pistas nos subúrbios de Atlanta, a polícia detectou Victor Harris dirigindo em velocidade acima do permitido.

Realizada a tentativa de parada do tráfego, Harris não obedeceu ao comando, prosseguindo em alta velocidade. O policial Timot Scott, mesmo sabendo pouco sobre o ocorrido, decidiu ajudar, por iniciativa própria, entrando na perseguição. A perseguição durou aproximadamente seis minutos por quatorze quilômetros, quando Scott pediu autorização para fazer uma manobra de intervenção forçada ao veículo perseguido, o que lhe foi atendido. Scott então procedeu à intervenção, realizando uma colisão proposital, com seu veículo, na parte traseira do carro de Harris, que veio a girar de forma descontrolada, saindo da estrada e caindo em um barranco (KAHAN, 2009). Harris sofreu uma fratura no pescoço que o deixou tetraplégico. Tudo isso foi alvo de gravação através de uma "dash cam" instalada no veículo do policial Scott, a qual foi apresentada no processo judicial, como instrumento probatório. Diante do ocorrido, Harris ajuizou ação sustentando que o uso de força reconhecidamente mortal para encerrar a perseguição teria sido inadequado, infringido, portanto, os termos da Quarta Emenda americana, instalando-se a controvérsia principal se Scott teria o direito a um julgamento sumário, sem análise do caso pelo júri (KAHAN, 2009). 
A perseguição foi gravada pela câmera do carro do policial Scott, cujas imagens encontram-se publicadas nas redes sociais ${ }^{3}$ :

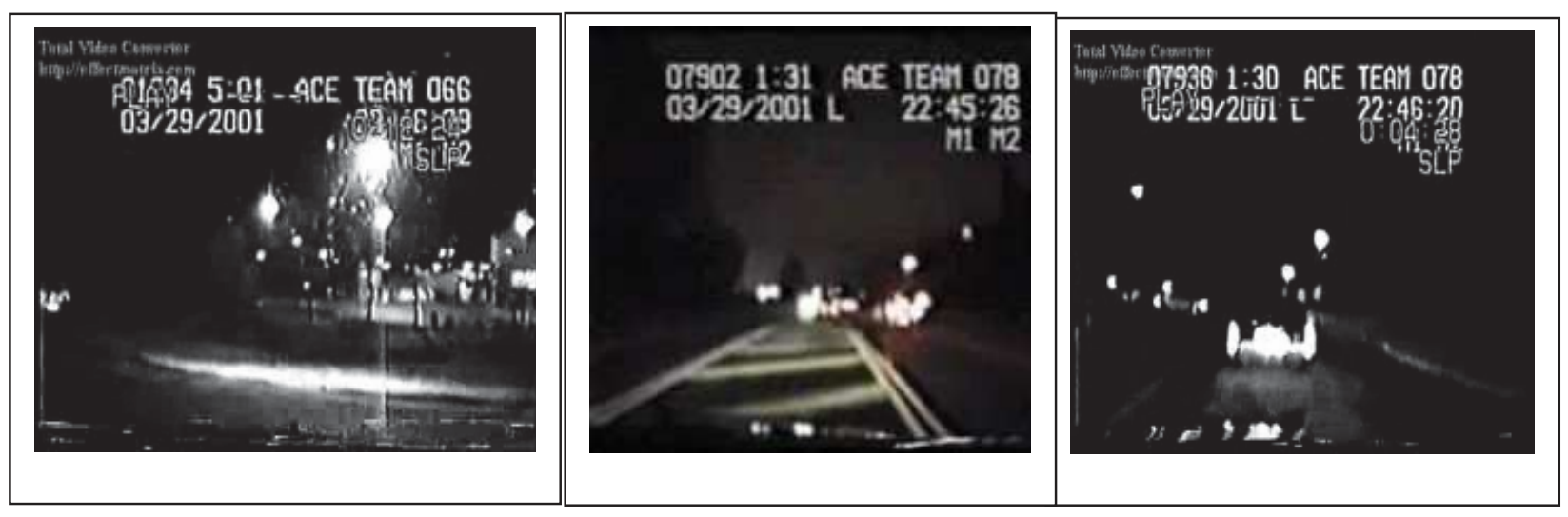

Seria o caso um exemplo de força excessiva na realização de uma prisão? (SHERWIN, 2019). Se jurados razoáveis poderiam discordar sobre a adequação do nível de força exercido pela polícia, então o julgamento sumário seria inadequado, cabendo ao júri analisar se os direitos da Quarta Emenda de Harris haviam sido violados (SHERWIN, 2019). O Tribunal do Décimo Primeiro Circuito decidiu que mentes razoáveis poderiam divergir se a força letal era necessária nessa situação e que, devido a isso, não seria adequado o julgamento sumário sobre os méritos da Quarta Emenda, merecendo o caso ser remetido ao júri, destacando, ainda, sua posição no sentido de que não havia justificativa para o uso de força mortal ante a ausência de ameaça real aos pedestres ou outros motoristas, pois as estradas estavam quase vazias e Harris permaneceu em controle de seu veículo (KAHAN, 2009). O parâmetro utilizado pelo tribunal foi o precedente Tennessee vs. Garner, no qual se estabeleceu que o uso de força letal somente estaria autorizado se houvesse uma causa provável para acreditar que o suspeito representasse uma ameaça significativa de morte ou lesão física grave para a polícia ou terceiros.

Apresentados os recursos cabíveis, o caso foi remetido para a Suprema Corte Americana que por uma decisão de oito a um, discordou (SHERWIN, 2019), tendo sido a prova produzida em vídeo determinante. A Suprema Corte entendeu que os fatos revelados no vídeo tornaram

\footnotetext{
${ }^{3}$ Disponível em https://vimeo.com/46603634
} 
indiscutivelmente claro o direito de Scott a um julgamento sumário, negando a possível existência de posições em sentido contrário. O juiz Scalia, em sua fundamentação destacou “longe de ser o motorista cauteloso e controlado, o tribunal de primeira instância demonstrou fotos, o que vemos no vídeo se assemelha mais a um estilo de perseguição de carro de Hollywood do tipo mais assustador, colocando policiais e inocentes espectadores igualmente com grande risco de lesões graves (KAHAN, 2009)."

Scalia e a Suprema Corte concluíram que os fatos deveriam ser vistos, única e exclusivamente, à luz do que retratado pela fita de vídeo, tendo em vista que esta demonstrava de forma tão manifesta a razoabilidade do uso de força letal que não havia necessidade de se aprofundar no precedente de Garner adaptando-o a uma perseguição de carro. Em sua argumentação oral Scalia disse que Harris "criou a cena de perseguição mais assustadora que eu já vi desde 'The French Connection" (KAHAN, 2009). Reafirmando sua posição de que o vídeo tinha apenas um interpretação óbvia e possível, Scalia fez uma cópia do vídeo para a Suprema Corte observando em nota de rodapé: "Estamos felizes em permitir que a fita de vídeo fale por si." O juiz Breyer disse ao advogado de Harris: "Eu olho para a fita e acabo com a velha pergunta de Chico Marx. Em quem você acredita, em mim ou seus próprios olhos?"

Stevens, contudo, divergiu, defendendo que a fita não falava por si e que pessoas, com experiências diferentes, poderiam ter outra percepção da realidade diante dos fatos retratados no vídeo, o que não foi suficiente, contudo, a mudar a posição dos demais membros da corte superior que entenderam não haver necessidade de enfrentar os argumentos apresentados pelo único juiz dissidente, mantendo a decisão de que nenhum jurado razoável poderia entender que Harris não havia causado risco mortal para o público com a fuga. Pelo contrário, o Tribunal disponibilizou em seu site o vídeo da perseguição e convidou o público a julgar o caso com base em seus instintos decorrentes da visualização das imagens, inovando em suas atitudes (KAHAN, 2009).

Scott foi inocentado pela Suprema Corte em julgamento sumário sem a participação do júri em uma decisão de oito a um. Kahan (2009), Silbey (2008) e Sherwin (2011) debruçaramse sobre o caso e, procedendo à estudo pormenorizado, acerca do tratamento dado à prova produzida em vídeo, concluíram pela existência de problemas em sua análise. Scott X Harris tornou-se, então, o caso referência sobre evidências visuais no âmbito processual (SHERWIN, 2019), servindo de base para os primeiros estudos sobre o tema. A partir daí, foram identificados alguns equívocos recorrentes na análise das provas imagéticas. A imagem fala por si, o ato de assistir ao vídeo transforma o telespectador em testemunha ocular dos fatos, abrindo uma janela para a realidade, o vídeo é objetivo e imparcial. Tais conclusões foram classificadas como mitos 
os quais vieram a ser desvendados através de teorias, tais como o iliberalismo cognitivo (FEIGENSON, 2014), o realismo ingênuo (SHERWIN, 2011), a testemunha silenciosa (silbey, 2008) e interpretação cruzada do filme (silbey, 2008), as quais serão abordadas em tópicos específicos.

\subsection{A imagem diz por si / Iliberalismo cognitivo / realismo ingênuo.}

A imagem pode nos dizer muito, mas não tanto quanto tendemos a pensar que sim. $\mathrm{O}$ poder persuasivo das imagens tem sido usualmente menosprezado, as pessoas têm apresentado convencimento exagerado em seus entendimentos e muito pouca receptividade a pontos de vista alternativos, o que demonstra prevalecer atualmente uma atividade particular de senso comum na simplória análise de acreditar que os elementos descritivos contidos nas imagens significam exatamente o que elas acham que veem nelas (FEIGENSON, 2014). Assim como a Suprema Corte Americana, muitos tribunais têm aplicado sumariamente o mito da imagem fala por si, sem proceder à correta análise das evidências visuais. Com isso, o sentido real da imagem tem sido ignorado em interpretações institucionais e judiciais às quais não têm demonstrado a atenção necessária na confiabilidade sobre as evidências imagéticas, imprimindo fé equivocada na capacidade dos métodos tradicionais de julgamento em gerenciar as fragilidades inerentes às novas e específicas evidências visuais.

Assim, observamos atualmente a ingênua concepção de que é fácil familiarizar-se com o meio visual, o qual supostamente não demandaria conhecimento específico para ser analisado. Essa tendência tem influenciado, inclusive, os “tomadores de decisão leigos" e membros de júri os quais têm sido equivocadamente incentivados a atribuir significado ou importância a imagens mesmo desprovidos de conhecimento para tal (EDMOND, 2013). Todavia, estudos empíricos sobre o leading case "Scott x Harris" demonstraram que a análise e interpretação de imagens vai muito além do mero ato de assisti-las, sendo impossível dar credibilidade à popular assertiva a "imagem diz por si", havendo muito mais a ser desvendado.

Dan Kahan (2009) e os demais pesquisadores apresentaram o vídeo da famosa perseguição policial a uma amostra diversificada de 1350 americanos, onde se verificou que, apesar da maioria ter concordado com a decisão do Tribunal, sobre a autorização para o uso da força letal, diversas subcomunidades tinham entendimentos diferentes sobre o julgamento. Assim, observou-se a ocorrência de certa padronização de pontos de vista, conforme identidade de grupos; afro-americanos de baixa renda e moradores do nordeste, por exemplo, demonstravam certa tendência em concordar com os argumentos do autor em detrimento aos do Tribunal; liberais e democratas, ante sua orientação cultural de valorização do igualitarismo e da solidariedade social, tendiam a atribuir maior responsabilidade à polícia e menor 
justificativa no uso de força mortal para encerrar a perseguição (KAHAN, 2009). Dessa forma, restou evidente que os padrões conclusivos tinham relação direta ao contexto social dos indivíduos e que esses tendiam a resolver os fatos disputados a favor de suas identidades culturais, ideológicas e psicológicas, o que também teria ocorrido em Scott x Harris, visivelmente perceptível pela insistência da Suprema Corte americana na existência de uma única e exclusiva visão razoável dos fatos exibidos na gravação (KAHAN, 2009).

Emergiu daí o conceito iliberalismo cognitivo segundo o qual se observa vício na tomada de decisão ante a influência subconsciente de vivências, crenças, educação e outros fatores ideológicos e culturais, os quais incidem diretamente na construção direta da realidade que vemos (SHERWIN, 2019). Isso desagua em uma decisão arrogante, contaminada pelo excesso de autoconfiança de não admitir que outros grupos de pessoas poderiam ter pontos de vista diferentes, fruto de dissonância de experiências de vida. Ao ignorar a possibilidade de interpretações e visões divergentes de seu ponto de vista, afirmando categoricamente que nenhum jurado razoável poderia formar crenças contrárias às do próprio Tribunal, a Suprema Corte americana investiu a lei com conotações culturalmente partidárias que prejudicaram a legitimidade da decisão, ferindo a integridade e inteligência de subcomunidades cujos membros mantinham crenças dissidentes, proferindo decisão viciada pelo iliberalismo cognitivo (KAHAN, 2009).

A maioria da corte não chegou sequer perto de estar ciente do grau em que suas próprias percepções estariam relacionadas aos aspectos culturais, ideológicos e outros compromissos éticos e morais que os dispunham a interpretar os fatos da mesma forma. Os membros da corte não foram humildes o suficiente para perceber e reconhecer que a situação fática observada na tela era potencialmente dissidente, o que poderia ser observado pelos próprios sujeitos principais da lide, policiais e pessoas do público, ou seja, grupos opostos (KAHAN, 2009). Falhou-se, assim, na tomada de decisão, que passou a ser preconceituosa, com excesso de confiança e ingenuidade, pois nitidamente influenciada pela conjuntura social e psicológica de vida experimentada pelos juízes - orientação cognitiva motivada por valor -, o que se tornou determinante para que se deixasse a "imagem dizer por si".

A incidência do iliberalismo cognitivo na decisão judicial traz à tona outro vício presente na interpretação imagética, o qual teria relação íntima com aquele, o realismo ingênuo. Segundo a psicologia social o realismo ingênuo ocorre devido à assimetria na capacidade dos indivíduos em identificar os efeitos da cognição motivada por valor. Isso se mostra perceptível no flagrante desequilíbrio no reconhecimento da influência da conjuntura social e psicológica na tomada de decisão; quando proveniente de grupos opostos torna-se tarefa fácil, o que 
demonstra a parte realista. A ingenuidade, contudo, se observa na reduzida capacidade de percepção do preconceito nas próprias convicções, ou seja, é difícil reconhecer em si a influência de fatores culturais e ideológicos; realismo ingênuo seria assim a tendência natural de detectar preconceitos de outras pessoas, mas não o próprio (SHERWIN, 2019).

O fato é que não se tem como reconhecer a existência de percepções perfeitamente neutras, as decisões são, ainda que de forma inconsciente e em grau não elevado, moldadas por crenças e expectativas, que por sua vez são influenciadas por fatores como educação, formação social e cultural e ideologia, o que, em conjunto, constroem a realidade de certo ponto de vista em virtude de eventual estímulo visual (SHERWIN, 2019). Nesse cenário, pode-se observar, na sociedade contemporânea, diversas e reiteradas decisões arrogantes, preconceituosas, imbuídas de verdadeiro excesso de confiança na capacidade de interpretar evidências audiovisuais. Analistas de políticas públicas, legisladores, juízes e advogados não se mostram cientes da própria inclinação para a formação de crenças factuais coerentes com sua cultura e compromissos estruturais, aliás, isso também ocorre com cidadãos em geral. O resultado disso é o realismo ingênuo que desagua no iliberalismo cognitivo.

Ambos os vícios foram observados na decisão de Scott x Harris, ao proceder ao julgamento sumário do caso sem remessa para o júri. As disputas factuais originadas de visões de mundo culturalmente conflitantes, policiais versus cidadãos, poderiam ter sido alvo de decisão muito mais legítima, admitindo-se a possível existência de pontos de vista opostos em relação ao vídeo apresentado, afastando-se o risco de decisão arrogante ou com excesso de confiança. Dessa forma, estaria se procedendo a uma decisão consciente, em que se reconheceria a possibilidade da influência de fatores culturais e ideológicos, extraindo da imagem a mais efetiva interpretação dentro do contexto fático jurídico.

O cenário do leading case americano tem se repetido pelos tribunais brasileiros. As provas imagéticas ora têm sido alvo de resistência em sua absorção ao campo processual e ora, quando admitidas, têm sido tratadas de forma superficial, sem o devido aprofundamento em sua interpretação. Ou seja, ora as imagens são admitidas e prevalecem "por si”, sem maiores considerações, tendo seu conteúdo supervalorizado, ora são pura e simplesmente rejeitadas, sequer se admitindo sua inserção ao campo probatório processual. Esse cenário conflituoso precisa ser modificado, demandando dos operadores do direito cautela e prudência, os quais precisam evitar a discrepância entre a supervalorização e a ignorância sobre a imagem, buscando meios de se alcançar a interpretação das evidências visuais de forma cética e consistente (PORTER, 2013). 
O intérprete precisa estar ciente da possível incidência do iliberalismo cognitivo e do realismo ingênuo, prevenindo-se do excesso de confiança naquilo que se vê e da crença de que se está verdadeiramente diante dos fatos, o que pode ocorrer, tanto pela velocidade quanto pelo poder dos sedutores elementos visuais. Além disso, as evidências visuais estão sujeitas a abusos e podem eventualmente vir a ser usadas sem a ética necessária, ou seja, as imagens podem enganar e o julgador não está imune a isto (MURRAY, 2013). Consciente e alerta, o intérprete pode se precaver e neutralizar a influência cognitiva social, minimizando o excesso de confiança de tornar o visualizado em premissa inatingível, levando em consideração que determinados grupos podem ter posicionamentos em sentido diametralmente opostos (SHERWIN, 2019).

O julgador deve, assim, reconhecer a possibilidade de sua incidência e identificar o emaranhado de interligações sociais dinâmicas que podem viciar a tomada de decisão sobre evidências imagéticas, o que requer humildade judicial. A humildade nasce da consciência dos limites de sua própria racionalidade trazendo a possibilidade de o magistrado repensar sua decisão decidindo, até mesmo, de maneira contrária a sua própria inclinação (KAHAN, 2009). Os Juízes devem se mostrar, portanto, sensíveis e humildes o suficiente para reconhecer a eventual existência de possíveis resultados divergentes aos seus pensamentos, a possível existência de grupos com entendimentos opostos, sendo recomendável a realização de uma pausa mental para analisar se, de fato, a questão factual analisada é tão óbvia ao ponto de não poder ser visto de forma diferente por uma subcomunidade discreta e identificável (KAHAN, 2009).

A intensidade e a forma de influência do iliberalismo cognitivo e do realismo ingênuo podem não ser totalmente perceptíveis pelo tomador da decisão, mas reconhecendo este que está sujeito a erros e que a cognição moldada por valor existe e pode moldar seu desempenho, aproxima-se de uma decisão mais justa, minimizando-se tais efeitos. Essa humildade não proíbe, todavia, os juízes de selecionar um resultado que provavelmente seja mais compatível com um estilo cultural ou outro, mas o exercício da pausa mental traz a cautela e prudência que valida a decisão. Portanto, como Dan Kahan e seus co-pesquisadores mostraram, a crença de que os vídeos falam por si é uma ilusão. Os julgadores, de fato, precisam de um maior preparo na análise da prova em vídeo, de modo a se garantir a imparcialidade da decisão.

2.6 Testemunha ocular, testemunha silenciosa, janela para a realidade, objetividade ou imparcialidade do vídeo, mito do cinema total, interpretação cruzada do filme (cross examining). 
Em 25 de julho de 2017, um skatista, transitando pela Rua Paulista, na cidade de São Paulo, foi atropelado por um veículo. Inicialmente, imagens de uma câmera de segurança mostraram um cidadão dirigindo o carro na contramão e acertando o skatista, que veio a chocarse ao vidro do carro. No mesmo dia, as referidas imagens foram divulgadas pela mídia o que causo grande comoção social, como se pode ver das imagens divulgadas por jornais abaixo ${ }^{4}$.

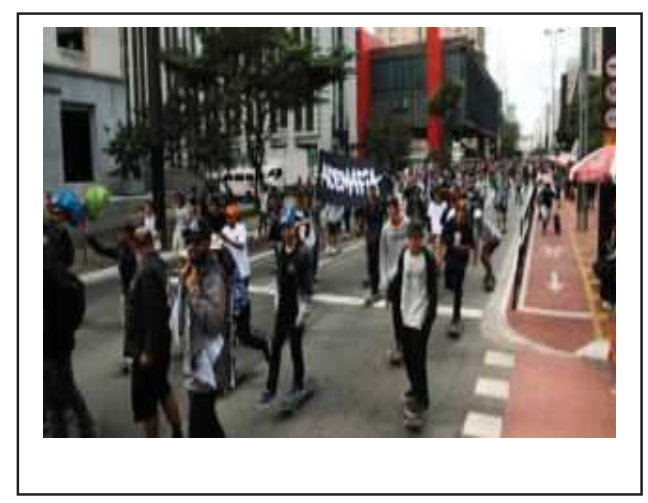

Todavia, dias depois, imagens de outra câmera, fixada sob outro ângulo, revelaram que, na realidade, o motorista do carro estava sendo perseguido e atacado por skatistas, o que o levou a adentrar na contramão e atropelar o rapaz. Tais imagens foram divulgadas na mídia trazendo discussão sobre o ocorrido e alterando o julgamento social dos fatos ${ }^{5}$. Percebe-se, assim, que o ângulo de fixação da câmera foi determinante para a averiguação da realidade (SALGADO e RICCIO, 2020).

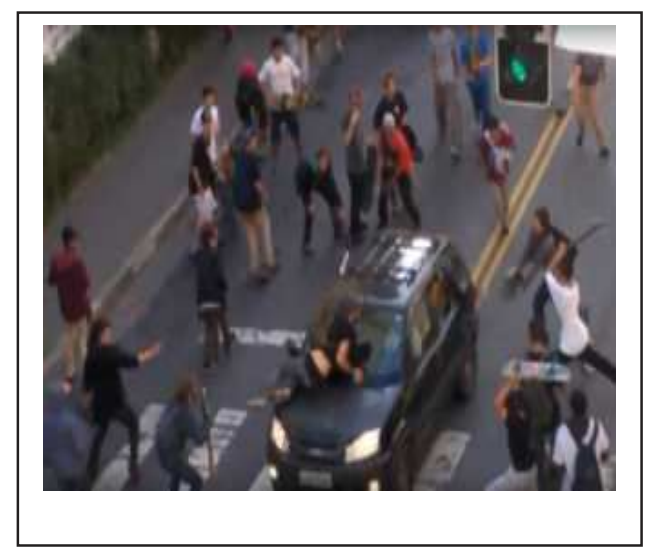

\footnotetext{
${ }^{4}$ Disponível em https://noticias.uol.com.br/cotidiano/ultimas-noticias/2017/06/25/skatista-atropeladona-rua-augusta-permanece-internado-policia-tenta-identificar-motorista.htm

${ }^{5}$ Disponível em https://m.folha.uol.com.br/cotidiano/2017/06/1896236-video-mostra-skatistasatacando-carro-antes-dele-invadir-trecho-interditado.shtml
} 
Outro caso emblemático que demonstra a possibilidade de alteração da interpretação dos fatos gravados em vídeo, pela mudança de ângulo da gravação, pode ser representado pela morte do cidadão negro americano George Floyd. Inicialmente surgiu na mídia a imagem abaixo na qual aparecia apenas um policial ajoelhado sob o pescoço do cidadão negro ${ }^{6}$ o que acarretou na prisão imediata de um único policial.

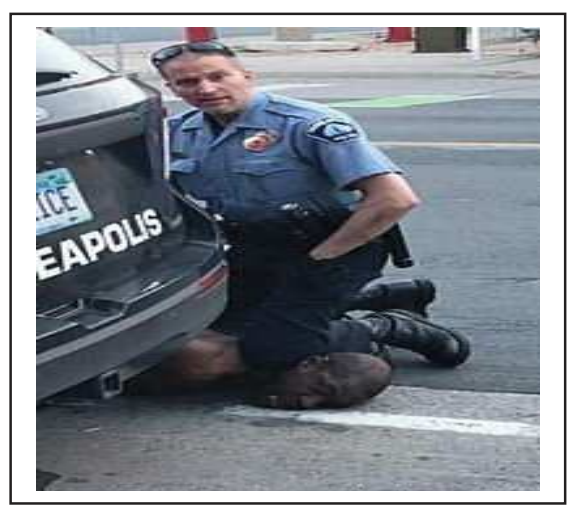

Dias depois, gravação sob outro ângulo trouxe a informação de que havia outros policiais ajoelhados sob o corpo de Floyd que também haviam participado da ação criminosa, o que acarretou nas prisões de mais envolvidos ${ }^{7}$.

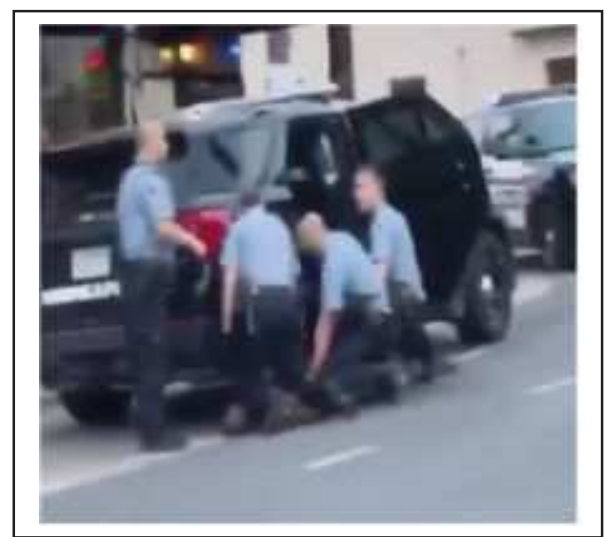

6 Imagem inicial em que aparecia apenas um policial na prática criminosa.

7 Ângulo reverso mostra que 3 policiais -e não apenas 1- se ajoelharam sobre Floyd, morto após não conseguir respirar 
Tal fato casou imensa comoção social e protestos antirracistas ocorreram por todo o mundo, como se pode ver da imagem abaixo divulgada na mídia:

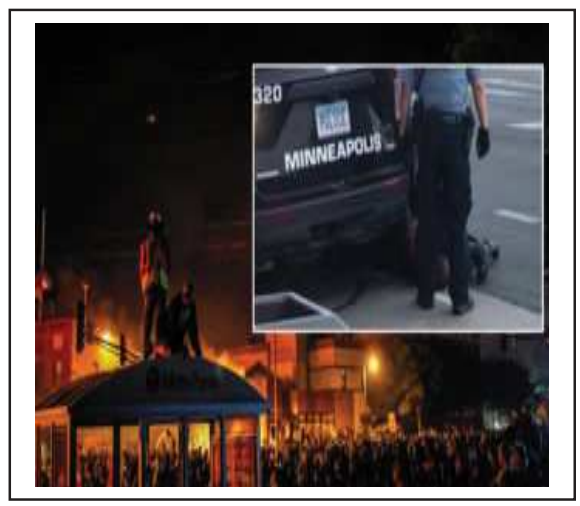

Diante disso, podemos indagar, seria a imagem um meio objetivo e imparcial intangível, transformando o telespectador em testemunha ocular dos fatos, abrindo uma janela para a realidade? Seria o vídeo uma testemunha silenciosa sobre o ocorrido? A imagem pode mentir?

Como vimos acima, as imagens gravadas em vídeo podem ser retratadas de formas e ângulos diferentes, podendo ser, inclusive, manipuladas socialmente para reforçar certa tese no interesse próprio de alguém. O que se quer com isso é demonstrar que o vídeo é um meio de comunicação construído (SALGADO, 2019) e a imagem sempre demonstra, de certa forma, um ponto de vista, sob um certo ângulo, no objetivo de alguém, que teve, no mínimo, a intenção de proceder à gravação. Logo, filmes são representações retratadas, artificialmente, mediante criação humana, a qual decide sob qual perspectiva será construída a narrativa, qual o ponto de vista será demonstrado, sempre havendo por trás de qualquer câmera algum ser humano que a controle, ainda que minimamente (MURRAY, 2014).

Ou seja, todo filme pode contar mais de uma história e menos que a história toda, há sempre a possibilidade de existir mais de uma versão da história a ser contada, oriunda de outra gravação de outro ângulo mudando toda a concepção da realidade. Não se pode olvidar, assim, que a imagem pode apresentar um único ponto de vista e, eventualmente, viciado; a imagem pode, portanto, mentir. Há de se verificar o ângulo da gravação, como foi efetivamente produzida, a fixação da câmera, a data do ocorrido, a hora exata da gravação; tudo isso pode evitar que a decisão jurídica se paute apenas em uma ilusão baseada em convenções e representações (SILBEY, 2004).

Assim, não se pode conceber que se transforme o espectador em testemunha ocular, como se estivesse diante dos fatos, tal como asserido pelo juiz Breyer em Scott x Harris (SILBEY, 2008). O Tribunal, na realidade, foi vítima do poder persuasivo do vídeo ao tratá-lo como captação inequívoca da realidade, incidindo, assim, na falsa premissa de acreditar nos 
próprios olhos, deixando que a "imagem falasse por si", quando na verdade as imagens retratavam apenas uma das versões dos supostos fatos ocorridos (KAHAN, 2009). Há de se ressaltar, contudo, que apesar da gravação representar uma posição monocular, a realidade do evento que está no coração do processo adjudicatório é, por sua natureza, multiocular (KAHAN, 2009).

O filme deve, portanto, ser tratado da mesma forma que as testemunhas, devendo ser interrogado e levado em confronto a todas as demais evidências existentes no processo, realizando-se, assim, uma interpretação cruzada do vídeo - o método de cross-examination film - (SILBEY, 2008) e garantindo-se uma interpretação de evidências visuais condizente com o devido processo legal e a justiça da decisão, justificativas da própria existência do sistema judicial, em si (SILBEY, 2012). Portanto, os fatos descritos em gravações fílmicas não são uma verdade absoluta, não se podendo considerar que a gravação seja uma testemunha silenciosa do ocorrido. Segundo tal teoria, as filmagens deveriam ter seu valor probatório reconhecido, desde que o vídeo fosse gravado através de processo confiável em que se retratasse a cena de forma precisa, o que permitiria deixar a câmera falar por si, abrindo-se uma janela para a realidade para que cada espectador pudesse testemunhar com seus próprios olhos os fatos (LÁZARO, 2018).

Partindo-se dessa premissa, estaríamos, de fato, considerando uma prova em vídeo como fotografia inatingível da realidade, desconsiderando totalmente o controle humano das gravações e a possível existência de subjetividade, parcialidade ou ambiguidade na criação do filme, incidindo no que chamamos de mito do cinema total (SILBEY, 2008). Ademais, com a propagação em massa de imagens, estaríamos abrindo uma "janela para realidade" para um número incalculável de pessoas que poderiam acatar como verdade absoluta a informação propagada, sendo proferido um julgamento social através das concepções populares de justiça - folk (RICCIO et al, 2016) -, o que poderia ser danoso a toda a sociedade, desaguando em vícios em decisões judiciais e comoção social (SHERWIN, 2011).

Portanto, o que se vê é que o intérprete deve se preparar para o enfretamento das provas produzidas em vídeo, sendo para tanto, um grande passo o fato de tomar ciência expressa acerca dos vícios clássicos acima identificados; a imagem, de fato, não fala por si. Há diversos aspectos a serem considerados. Ela precisa ser interrogada e levada em confronto aos demais elementos de prova; quando se assiste ao vídeo não se está assistindo ao fato em si; a gravação não é uma testemunha silenciosa e não retrata a realidade de forma inequívoca, imparcial e objetivamente.

Tomando ciência da necessidade de desmistificação desses vícios, o intérprete terá avançado na tarefa de se garantir um sistema judicial mais justo, onde todos os elementos de 
prova são analisados e interpretados de forma séria, cautelosa, prudente e fundamentada, avançando o julgador na efetiva realização de alfabetização visual.

\subsection{Alfabetização visual.}

Como podemos observar acima, os estudos sobre a absorção das provas em vídeo ao campo processual revelaram a existência de vícios analíticos recorrentes em diversas comunidades jurídicas, demonstrando, assim, que o modelo tradicional de Direito e educação jurídica têm sido incapazes de compreender e acompanhar as modificações sociais decorrentes da tecnologia. Afinal, a cada avanço tecnológico, a prática do direito torna-se mais sofisticada e, proporcionalmente, a esse progresso, o sistema jurídico precisa se adaptar (SHERWIN, 2019). Contudo, o que se tem verificado, em alguns momentos, é um impasse evolutivo entre o exponencial crescimento da produção de provas imagéticas e sua adaptação ao ramo jurídico, o que tende a possibilitar decisões injustas e em contraposição ao real sentido das provas contidas nos processos judiciais.

Tal como na justiça norte-americana, inconsistências e imprevisibilidade, tanto no procedimento, quanto na interpretação das imagens, parecem ocorrer na justiça brasileira, inclusive trabalhista. Como veremos na análise qualitativa dos casos escolhidos, em alguns momentos as provas em evidência visual são inadmitidas sem fundamentação consistente; as mídias com as imagens, às vezes, não são remetidas de forma imediata ao grau de jurisdição respectivo e as interpretações do imagético revelam, em certa medida, interpretação superficial, o que parece demonstrar uma resistência na utilização do imagético e dificuldades em decodificar o real significado do visual. Isso revelaria a necessidade da superação da lógica e cultura jurídicas essencialmente formais e racionais através de uma alfabetização visual do ramo jurídico.

Nesse contexto, a alfabetização visual teria como objetivo o aprendizado de interrogar imagens de forma crítica, colher a real informação daí advinda e proceder à deliberação consistente, o que pressuporia uma capacidade reflexiva informada por instrumentos conceituais e retóricos. Dessa forma, seria possível e viável uma avaliação mais significativa de como palavras, sons e imagens revelam um significado, possibilitando-se a devida compreensão dos elementos culturais e cognitivos da criação de significado visual (SHERWIN, 2019). Isso nos aproximaria da tomada de decisão justa corrigindo o atual quadro de análise equivocada dos elementos imagéticos.

Os elementos da retórica visual inspiram pensamento inventivo sobre a lei construindo significado persuasivamente poderoso perante o público (MURRAY, 2013). Por isso, não basta apenas saber operar as máquinas e ter conhecimento para proceder à captação das imagens na 
tela, bem como manipular e analisar tecnicamente imagens em movimento para se tornar alfabetizado visualmente (SHERWIN, 2019). Primordial se torna o aprimoramento do conhecimento emocional e dos métodos interpretativos da narrativa e expressão visuais, através do desenvolvimento de uma capacidade cognitiva para compreender as características da imagem e seu impacto no cotidiano, refutando-se o negacionismo da imagem (SHERWIN, 2019).

Há de se incorporar, também, uma lógica descritiva e pragmática, com novos elementos de eloquência e argumentação visuais, a qual consiga decifrar os elementos metafísicos inscritos no âmbito da imagem, desenvolvendo-se a habilidade de ler e compreender seu conteúdo, garantindo-se seu entendimento adequado (SHERWIN, 2019). Todo esse necessário aprendizado decorre dos caracteres inovadores da imagem - tal como destacamos nos tópicos acima - e do fato de que a extração do real significado das imagens está diretamente ligada a processos tipicamente não-reflexivos de interpretação e associação afetiva, o que demanda absorção de informações de várias disciplinas, principalmente nos quesitos capacidade e vontade de exercer reflexão crítica. (SHERWIN, 2019).

Os juristas precisam estar cientes de que há mais no ato de entender ou interpretar criticamente as imagens na tela do que apenas assistir, os profissionais do direito precisam ter a humildade de aceitar que precisam cultivar certos tipos de conhecimento. Os discursos amparados por evidências visuais possuem poder de persuasão que destaca a retórica na construção de significado e melhora a capacidade e o poder de convencimento do discurso jurídico em conteúdo, arranjo e estilo (MURRAY, 2013), fazendo com que a correta e sábia utilização da prova em vídeo possa ser muito útil aos sujeitos processuais, ante a revolução digital que ora vivenciamos.

Tudo isso envolve toda a comunidade jurídica, acadêmica e profissionais do Direito. Os advogados devem cumprir a responsabilidade profissional de usar as melhores práticas para representar os interesses de seus clientes na lei prática, membros do judiciário devem ter o conhecimento necessário para interpretar os discursos visuais e os acadêmicos precisam debruçar-se sobre o tema que se mostra novo, desafiador e carecedor de pesquisas efetivas e eficientes. Sob qualquer ótica que se analise, portanto, a alfabetização visual se mostra necessária (PORTER, 2013).

Para isso, há de se ampliar o instrumental dos operadores do Direito, privilegiando a busca por conhecimento interdisciplinar de diversas áreas como publicidade, antropologia, história da arte, psicologia e retórica, o que ajudará na decodificação cognitiva e cultural dos processos de captação e disseminação visual (SHERWIN, 2019). Aliada à busca de tais 
conhecimentos teóricos multidisciplinares, há de se dar o devido aprofundamento à prática do Direito para que os estudantes e os atuais e futuros profissionais da área desenvolvam o conjunto de habilidades práticas necessárias para construir e desconstruir narrativas visuais. Assim se procedendo, aprimorar-se-á o conhecimento técnico sobre as tecnologias visuais e sobre os diversos modos de assimilação perceptiva e cognitiva da imagem. (SHERWIN, 2019).

Ademais, além da busca de conhecimentos de disciplinas diversas, torna-se essencial o estabelecimento de regramento expresso e específico para a análise das provas imagéticas, traçando limites e regras mais claras acerca de sua interpretação, valoração e admissibilidade (PORTER, 2013).

Com a absorção de conhecimentos específicos de diversas disciplinas e a difusão de cursos multidisciplinares teóricos e práticos e o regramento expresso, pode-se afastar os julgamentos precipitados, realizados de forma intuitiva, contaminados pela emoção imediata, bem como os vícios e mitos recorrentes na análise e na admissibilidade da prova em vídeo. Os educadores do Direito terão, também, de se adaptar ao tempo, ministrando cursos abrangentes de todos os tipos de evidências e estratégias visuais, contendo evidências demonstrativas, gráficos, reconstituições animadas, vídeos de vigilância (incluindo versões alteradas), vídeos com impacto na vítima e lesões pessoais no dia a dia, minidocumentários, juntamente com uma variedade de argumentos de fechamento visual.

Tudo isso faria com que um exame holístico do ambiente sensorial de julgamento fosse mais eficaz na análise do argumento visual, trazendo à tona todos os elementos hábeis para tal, incluindo exibições visuais, mas em conjunto às performances dos demais participantes (TAIT, 2007). Dessa forma, a solução para a compatibilização do Direito e o avanço desproporcional da tecnologia perpassa pelo efetivo preparo dos advogados, juízes e membros da comunidade jurídica para o enfrentamento das evidências visuais trazidas ao mundo processual. A ministração de cursos de diversas áreas de forma interligada seria o principal meio de se promover à alfabetização visual do ramo jurídico, tais como aqueles na graduação e na pós graduação; para ingresso na magistratura; ordem dos advogados do brasil e ministério público, os quais poderiam, também, incluir em seus editais matérias relacionadas ao preparo da análise de evidência visual; além das diversas instituições públicas atreladas ao campo jurídico.

Portanto, a alfabetização visual dos operadores do Direito requer extrema urgência, a tecnologia tem avanço incessante e a tomada de decisão justa e equilibrada depende da humildade judicial de se reconhecer a necessidade de todo esse novo aprendizado. 


\section{3 - METOdologia - ESTUdo QUALITATIVO DE CASOS CONCRETOS EM PROFUNDIDADE.}

O presente estudo tem como objetivo principal responder se a necessidade de alfabetização visual dos operadores do Direito, tal como proposta pelos autores norteamericanos, acima destacados, aplica-se ao ramo do Direito Processual Trabalhista brasileiro, destacando as peculiaridades e especificidades acerca da análise das provas em vídeo, observadas em tal seara. Assim, optamos pela pesquisa empírica como método de averiguação da questão principal, por se tratar de meio científico hábil a verificar assertivas sobre o mundo, amparadas em experiência ou observação, o que se amolda perfeitamente ao estudo em epígrafe, assim como em diversos outros que se pautam em dados obtidos de decisões judiciais (EPSTEIN, KING, 2012). Nossa escolha metodológica foi baseada, também, pelo delineamento de objetivos prévios e específicos, seguindo as diretrizes dos principais estudiosos da metodologia científica, para que possamos atingir resultados com o maior grau de confiança e exatidão possíveis, em um universo de colheita empírica de dados (YIN, 2015).

A base da pesquisa se pautará, assim, em método qualitativo de estudo de casos concretos, em profundidade, na qual buscaremos compreender todo o fenômeno social sobre a inserção da prova em vídeo nos processos trabalhistas, de um modo aberto, onde seja permitida a análise de todas as teorias, vertentes, peculiaridades e especificidades existentes sobre a questão principal e seus desdobramentos. A opção pela pesquisa qualitativa justifica-se pela maior amplitude de interação entre o pesquisador e o objeto a ser pesquisado, por meio do qual, através de observação detalhada, explicitaremos, de forma apurada e detalhada, todo nosso ponto de vista, opinião e perspectiva, em virtude dos dados coletados, em condições reais e nos contextos sociais pelos quais o estudo se realiza (YIN, 2015). A intenção da pesquisa é atingir razoável nível de objetividade tanto na coleta de dados, quanto na análise, exposição e conclusão, evitando-se, assim, vício da pesquisa por subjetividade, o que será levado em consideração ao procedermos ao isolamento de algumas variáveis e com a fixação de parâmetros prévios a serem analisados nas decisões judiciais.

Dessa forma, optamos pelo estudo de casos múltiplos, escolhidos por sua natureza crítica e reveladora, por meio do qual pretendemos observar diversas circunstâncias sobre a inserção e análise da prova em vídeo no processo trabalhista, às quais demonstrarão se as proposições da teoria suporte são verdadeiras ou não, maximizando, dessa forma, a possibilidade de generalização e replicação da análise, em contextos diferentes, além de alcance de conclusões mais robustas e de melhor qualidade (YIN, 2015). O foco será qualitativo pela ênfase no aprofundamento da compreensão de um grupo social sobre questões relevantes - em 
detrimento à preocupação com a representatividade numérica e quantificação dos resultados em critérios puramente objetivos, tal como se dá com as pesquisas quantitativas - atentando-nos, dessa forma, à objetivação dos fenômenos a serem estudados; à hierarquização das ações de descrever, compreender e explicar; à precisão das relações entre o global e o local; às diferenças entre o mundo social e o mundo natural; ao respeito à interatividade entre os objetivos, os parâmetros teóricos e os dados empíricos dos investigadores e à busca de resultados com maior fidedignidade (GERHARDT E SILVEIRA, 2009). A revisão das teorias existentes já foi devidamente realizada no capítulo 2 supra, o que foi realizado no objetivo de obtermos subsídios para a construção do problema de pesquisa e ampliarmos a credibilidade dos resultados, demonstrando-se, também, que o estudo se pauta na literatura mais atualizada disponível (EPSTEIN; KING, 2012).

Após a revisão da literatura e elucidação dos métodos, ora realizada, passaremos às digressões teóricas em relação às especificidades das provas em vídeo, em âmbito trabalhista, no objetivo de contextualizar a abordagem processual aos caracteres próprios do Direito Processual do Trabalho. Em continuidade, teremos o início da coleta de dados a qual se baseará nos parâmetros de pesquisa a serem identificados nas decisões judiciais (YIN, 2015). Será realizado, assim, estudo qualitativo de três casos contemporâneos, em profundidade, em contexto ao mundo real e em atenção à integralidade de teor das decisões proferidas nos processos.

A escolha da análise de decisões judiciais, de primeira e segunda instâncias, do Tribunal Regional do Trabalho do Rio de Janeiro (TRT1), se deu em virtude de representar estado de grande importância econômica e social para o país, no qual tem havido constante incidência de provas produzidas em vídeo. As decisões sobre as quais nos debruçamos estão disponíveis, ao público, na internet, o que facilitará seu estudo por meio eletrônico. A forma de coleta das decisões e o lapso temporal baseou-se na contemporaneidade, através de pesquisa ao site institucional do Tribunal Regional do Trabalho da primeira região, em uma busca com as palavras-chave "prova" e "vídeo", nos anos de 2019 e 2020.

A forma de escolha destes casos foi racional e direcionada, dentro do contexto consideravelmente numérico de resultados da busca, tendo sido feita a opção por estudo de três casos em gradação no objetivo de demonstrar de uma forma mais abrangente os diferentes tipos de decisões em relação às diversas situações inovadoras existentes sobre a prova em vídeo, em comparação aos parâmetros teóricos delimitados pela revisão de literatura. Assim, a escolha foi por um caso de inadmissão da prova em vídeo, um de decisão sem reforma pelo segundo grau de jurisdição; um de alteração do julgamento em sede de segundo grau de jurisdição. A intenção 
é responder à pergunta direta se há a necessidade de preparo ou alfabetização visual dos operadores do Direito Processual Trabalhista procedendo à análise do modo de abordagem e interpretação e a respectiva habilidade dos magistrados e desembargadores acerca das provas em vídeo, sendo que, para tal, propusemos a realização de indagações diretas e específicas, para limitar o objeto da pesquisa e torná-lo efetivamente contributivo para os operadores do Direito.

Não será reproduzido o inteiro teor das decisões, tampouco dos processos em sua integralidade, mas tão somente as informações relevantes no tocante à prova em vídeo, sendo omitidas questões processuais sem relevância ou elo para com o objeto do presente estudo. Adotamos, assim, um padrão sequencial no qual descreveremos as informações técnicas do processo; número do processo, juízo de primeira instância; turma julgadora do recurso e data de prolação das decisões. Os nomes das partes e dos intérpretes serão omitidos para resguardarmos certa privacidade aos sujeitos do processo, apesar da notória publicidade do processo ditada pela lei e concedida pelo Tribunal em seu sítio eletrônico.

Além de parâmetros para a descrição do caso, procederemos a questionário qualitativo sobre a forma como a prova em vídeo foi tratada e abordada pelos magistrados e desembargadores, com o seguinte padrão: 1 - o juiz de primeiro grau ou o desembargador, de fato, assistiram à prova produzida em vídeo e em que momento processual, em mesa de audiências ou fora dela? 2 - as imagens foram relevantes para o deslinde da controvérsias jurídica tendo sido mencionadas na fundamentação das decisões? 3 - foram respeitados os princípios do devido processo legal, contraditório e vedação à decisão surpresa (interdisciplinaridade com o Processo Civil)? 4 - o conteúdo das imagens foi expressamente impugnado por alguma parte, de modo a se tornar necessária a produção de prova pericial do vídeo apresentado? 5 - as demais provas dos autos foram levadas em confronto às imagens analisadas? 6 - restou evidenciada a necessidade de alfabetização visual? Ademais, segundo a revisão da literatura acima realizada, foram verificadas condutas clássicas na inserção e análise de provas em vídeo, nas decisões judiciais, ao redor do mundo, às quais foram denominadas como vícios ou mitos, o que servirá de base para averiguarmos se o mesmo tem ocorrido na justiça trabalhista brasileira.

Assim, será verificada a presença dos seguintes mitos: a) equilíbrio entre a revolução tecnológica e a receptividade da prova imagética (SHERWIN, 2011); b) resistência na absorção da prova em vídeo decorrente das características contrapostas da Mídia e do Direito (RICCIO et al, 2016); c) falha procedimental; d) a imagem diz por si (KAHHAN, 2009); e) janela pra realidade, imparcialidade do vídeo, testemunha ocular, testemunha silenciosa (SILBEY, 2004, 2008, 2012); f) ausência de interpretação cruzada do filme (SILBEY, 2012); g) iliberalismo 
cognitivo (FEIGENSON, 2014); h) necessidade de atualização de conceitos legais como a argumentação jurídica e cultura jurídica (RICCIO, et al. 2016); i) prova em vídeo ignorada ou supervalorizada (PORTER, 2013). Tais questões serão analisadas nas decisões contidas nos processos, principalmente sentenças e acórdãos. Ao final de cada caso será realizada uma tabela com a identificação dos problemas e questões relevantes de acordo com a literatura, no seguinte padrão:

TABELA DE PARÂMETROS QUALITATIVOS N. 1 - PROBLEMAS OBSERVADOS NA REVISÃO DE LITERATURA:

\begin{tabular}{|l|l|l|}
\hline $\begin{array}{l}\text { a) desequilíbrio da tecnologia e } \\
\text { o Direito. }\end{array}$ & ACÓRDÃOS \\
\hline $\begin{array}{l}\text { b) resistência na absorção da } \\
\text { prova em vídeo. }\end{array}$ & \\
\hline $\begin{array}{l}\text { c) desanização } \\
\text { administrativa. }\end{array}$ & \\
\hline d) a imagem diz por si. & \\
\hline $\begin{array}{l}\text { e) janela pra realidade, } \\
\text { imparcialidade do vídeo, } \\
\text { testemunha ocular, testemunha } \\
\text { silenciosa. }\end{array}$ & & \\
\hline $\begin{array}{l}\text { f) frágil interpretação cruzada } \\
\text { do filme. }\end{array}$ & & \\
\hline $\begin{array}{l}\text { g) iliberalismo cognitivo e } \\
\text { influência da emoção. }\end{array}$ & & \\
\hline $\begin{array}{l}\text { h) necessidade de atualização de } \\
\text { conceitos legais. }\end{array}$ & & \\
\hline $\begin{array}{l}\text { i) prova em vídeo ignorada ou } \\
\text { supervalorizada. }\end{array}$ & & \\
\hline
\end{tabular}

TABELA DE PARÂMETROS QUALITATIVOS N. 2: PONTOS RELEVANTES ABORDADOS.

PARÂMETROS: 


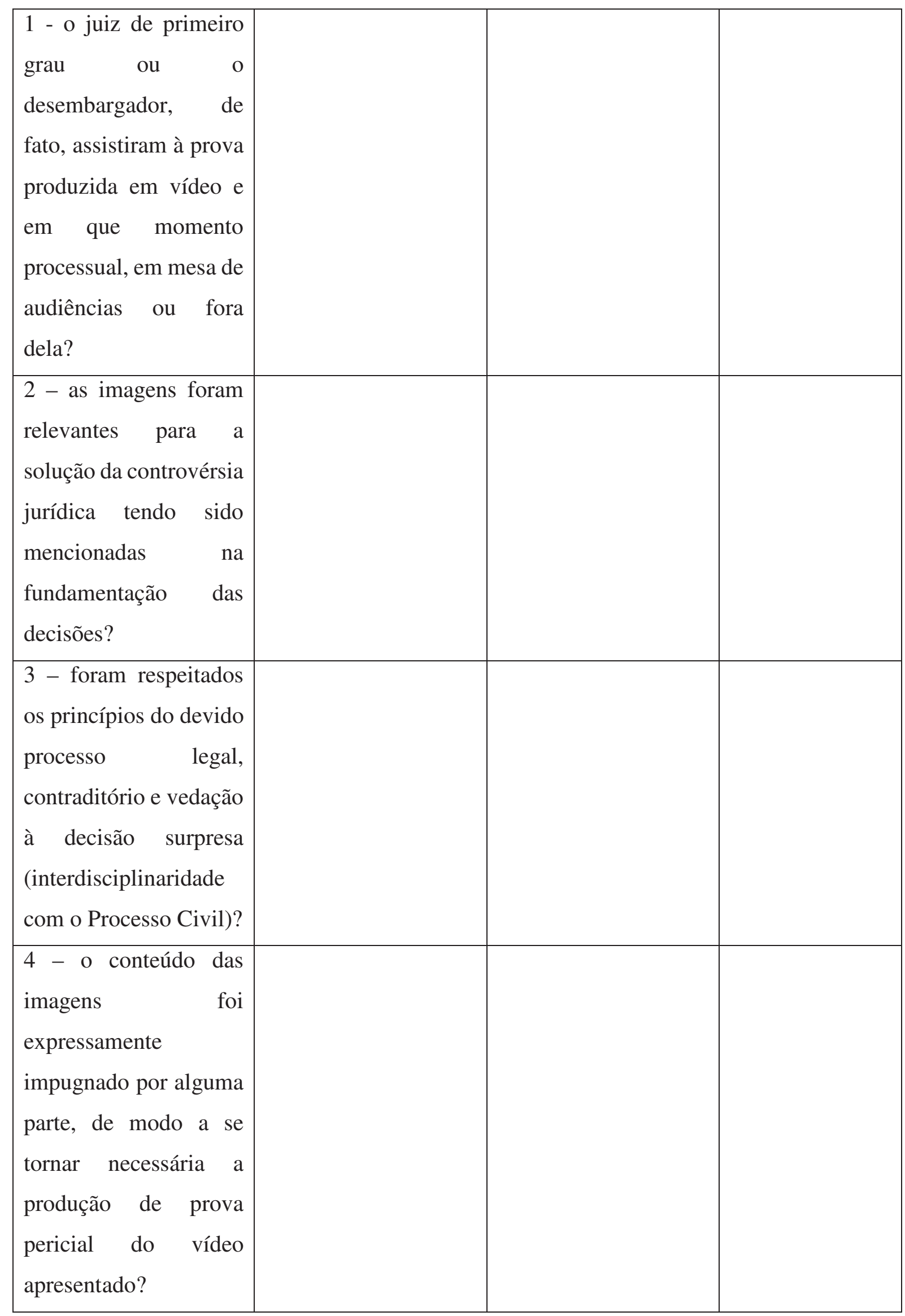




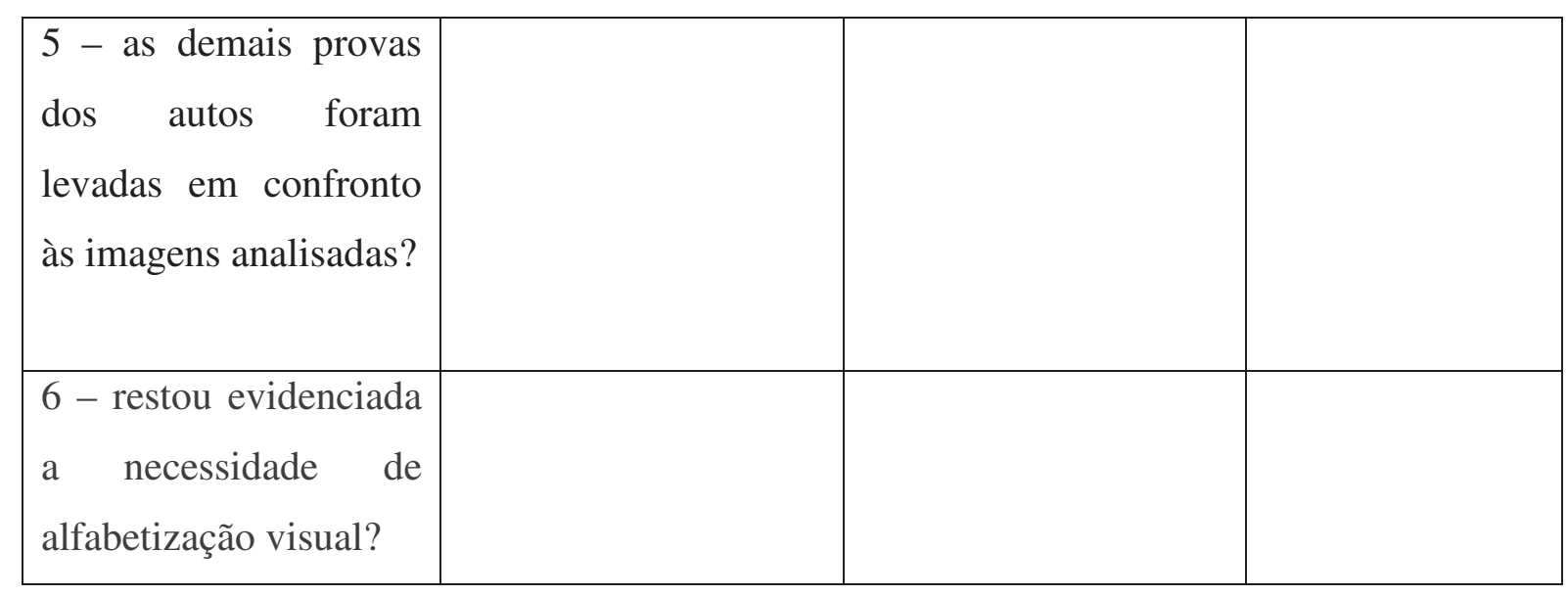




\section{4 - ARCABOUÇO PRINCIPIOLÓGICO TRABALHISTA E A PROVA EM VÍDEO.}

O Direito Processual tem por natureza intrínseca a instrumentalidade com a finalidade específica de tornar efetivo o Direito Substantivo o qual, no estudo em epígrafe, é o direito material trabalhista. Assim, o processo deve se adequar à natureza dos direitos controvertidos, o que justifica a existência de um ramo processual específico o qual guarde relação direta para com as características e peculiaridades dos direitos decorrentes de uma relação de trabalho, essencialmente diferentes dos direitos civis, penais ou administrativos (SCHIAVI, 2019). Emerge daí, o conceito de Direito Processual do Trabalho segundo o qual este se constitui em ramo das ciências jurídicas cujo objetivo é ditar as normas instrumentais para a atuação dos sujeitos processuais, em todos os procedimentos concernentes à matéria do trabalho, através de conjunto específico de princípios, normas e instituições. Esse conjunto de regras disciplina toda a atividade da Justiça do Trabalho, sempre na busca de se alcançar a efetividade da legislação trabalhista e social, além da concretude dos direitos trabalhistas, assegurando o acesso do trabalhador à justiça (SCHIAVI, 2019).

A legislação processual visa, portanto, impulsionar o cumprimento da legislação trabalhista e pacificar a relação jurídica capital versus trabalho, garantindo a efetividade de diretos (SCHIAVI, 2019) cuja característica principal é a natureza alimentar, derivando daí o papel de incidência destacada de alguns princípios processuais cíveis e trabalhistas, além de iter procedimental diferenciado em relação aos diversos atos processuais (LEITE, 2018). Por exemplo, o princípio da oralidade, próprio de Direito Processual Civil, tem maior relevo no processo trabalhista no qual se verifica maior intensidade do procedimento de audiência das partes. Há, assim, certo destaque da palavra oral, priorizando-se o procedimento de audiência, onde as partes expõem oralmente suas razões e as testemunhas prestam seu depoimento (SILVA, 2015).

Decorre daí a atuação enfática do princípio da concentração dos atos processuais em audiência, segundo o qual se deve dar prevalência na realização dos atos processuais em audiência e, especificamente, no âmbito trabalhista, em audiência única. Isso porque se está buscando a satisfação de um direito alimentar, urgente, o que torna imperioso dar celeridade ao processo (GODINHO, 2019). Assim, a incidência diferenciada do princípio da oralidade e celeridade ditam que em uma mesma audiência devem ser recebidas a inicial e a defesa, proposta a conciliação, resolvidos os incidentes processuais, fixados os pontos controvertidos, produzidas as provas, tais como a oitiva das partes e testemunhas, prolatando-se a decisão (SCHIAVI, 2019). Logo, percebemos que o legislador definiu procedimento diferenciado em 
relação aos outros ramos do direito processual, sendo a celeridade processual palavra de ordem na Justiça do Trabalho (CASSAR, 2019).

Mauro Schiavi (2019) destaca com clareza a importância da audiência no processo trabalhista e a concentração de diversos atos os quais, no processo civil, são praticados de forma separada e com vários prazos, no processo laboral, são concentrados num único grande ato, que é a audiência. Cabe trazer suas assertivas na literalidade:

O Processo do Trabalho, na expressão popular, é um processo de audiência, pois os atos principais da fase de conhecimento se desenvolvem nesse ato. Além disso, a lei determina que todos os atores principais do processo estejam presentes na audiência. De outro lado, o Juiz do Trabalho, como regra geral, toma contato com a inicial pela primeira vez na audiência e também com a defesa, que é apresentada em audiência (escrita ou verbal), tenta a conciliação, instrui e julga a causa (SCHIAVI, 2019).

Observamos abaixo uma síntese das peculiaridades do trâmite processual trabalhista, com rito mais célere e enxuto, baseado na oralidade, informalidade, simplicidade e concentração dos atos processuais, tudo em virtude da necessidade de se imprimir celeridade na efetivação de direitos alimentares emergenciais.

Por exemplo, a) A reclamação trabalhista pode ser verbal e o trabalhador pode fazer uso do jus postulandi, acionando a justiça sem advogado; b) não há despacho de recebimento da petição inicial; c) o juiz do trabalho normalmente toma conhecimento do feito na sala de audiências; d) a abertura da audiência ocorre com a tentativa de conciliação, sendo que após a tentativa frustrada de conciliação, é realizada a leitura da petição inicial; e) lida a inicial, passase ao recebimento da defesa em vinte minutos de forma oral (conforme artigo 847 da CLT) e à instrução do feito com a oitiva das partes e testemunhas (em regra limitada a 3 (três) testemunhas por parte) devendo estas, em regra, comparecerem independentemente de intimação; f) a audiência, em regra, é única e contínua; g) terminada a instrução, poderão as partes aduzir razões finais, em prazo não excedente de 10 (dez) minutos para cada uma e, em seguida, o juiz renovará a proposta de conciliação, proferindo a decisão, em caso negativo.

Como se vê, há diversas regras no objetivo de se imprimir a celeridade necessária à efetividade dos direitos alimentares em questão. Em decorrência disso, outros princípios foram estabelecidos como parâmetro processual, tal como se dá com a instrumentalidade das formas, segundo o qual o processo é mero instrumento a serviço do direito e da justiça, por meio do qual o juiz promove a pacificação social dando a cada um o que é seu por direito. Assim, em seara trabalhista, privilegia-se diferenciadamente o aproveitamento dos atos processuais desde 
que atingida sua finalidade, ainda que não praticados sob a forma prevista em lei (artigo 244 do CPC).

Decorrente da oralidade e instrumentalidade, temos o princípio da simplicidade das formas o qual traça como norte a ausência de formalismos extremos no campo processual trabalhista, sendo flexibilizada a solenidade de diversos atos processuais, desde que não resultem em prejuízo a qualquer parte (LEITE, 2018). Além da aplicação enfática de princípios cíveis, o ramo processual trabalhista é dotado de princípios específicos como o princípio da primazia da realidade sobre a forma, de onde deriva o enfoque na busca da verdade real, extraído do artigo 765 da CLT o qual preconiza "Os Juízos e Tribunais do Trabalho terão ampla liberdade na direção do processo e velarão pelo andamento rápido das causas, podendo determinar qualquer diligência necessária ao esclarecimento delas." Aliás, o processo trabalhista é informado pelo princípio da finalidade social do processo de cuja observância decorre uma atuação mais ativa do juiz no sentido de se promover à pacificação social permitindo a busca de uma solução justa para as partes (LEITE, 2018).

Em suma, a incidência dos princípios da celeridade, informalidade, simplicidade, oralidade, instrumentalidade das formas, concentração dos atos processuais, primazia da realidade e finalidade social do processo, fizeram com que o processo trabalhista fosse dotado de trâmite processual diferenciado, mais célere e compacto. Isso facilita, consideravelmente, a incidência das provas em vídeo, tornando o uso de tais estratégias probatórias ainda mais corriqueiro, desafiando os intérpretes a enfrentar tais inovações de forma habitual, o que requer maior preparo, prudência e cautela. Assim, observamos que a modernização do campo probatório tem desaguado constantemente nos processos trabalhistas, ante a facilidade na produção de imagens possibilitada pela revolução tecnológica que ora vivenciamos. As partes, portanto, têm se utilizado de diferentes formas de convencimento do magistrado, ora apresentando gravações no objetivo de provar algo diretamente sob a forma de evidência substantiva, ora apresentando evidências de forma demonstrativa, no objetivo de ilustrar argumentos (SILBEY, 2004), ou até mesmo unindo as duas evidências, como podemos observar de fotos de câmeras aliadas a gráficos e desenhos, tudo no objetivo de demonstrar a tese sustentada.

Por exemplo, podemos observar abaixo caso concreto8 no qual a empresa ré alegou que aplicara corretamente a justa causa a trabalhadoras aprendizes, por ato de indisciplina, em

\footnotetext{
${ }^{8}$ Processo n. 0101779-48.2016.5.01.0401, disponível em http://pje.trt.1.jus.br, consulta em 20/05/2021.
} 
virtude de terem sido flagradas dormindo no banheiro feminino, dentro da empresa e no horário de trabalho. No intento de provar sua tese a empresa colacionou fotos às quais foram tiradas por uma funcionária da segurança empresarial, no momento da ocorrência dos fatos, aliadas a descrição dos fatos, com setas indicativas, tudo de forma bastante ilustrativa. O caso foi julgado improcedente, tendo sido dado razão à empresa e considerada correta a aplicação da justa causa por ato de indisciplina, o que demonstra que as imagens tiveram poder de persuasão destacado. Abaixo pode-se observar esquema demonstrativo trazido pela empresa:

Das Providências: A Segurança Patrimonial em ato continuo solicitou junto à empresa Condor Security uma vigilante feminina para que fosse feita uma vistoria no interior do banheiro.

Durante a vistoria foi encontrada seis jovens aprendizes deitadas durante o horário de serviço.

Fica registrado que segundo relato das jovens aprendizes a vigilante feminina 40013171 Cleonice Silva (Empresa Condor Security) também estava no interior do banheiro e na mesma situação delas.

Dos Fatos: Deixo registrado que na data de 22/01/2016 por volta de $09 \mathrm{~h} 49 \mathrm{~min}$, A segurança Patrimonial recebeu a informação que havia algumas funcionárias que estavam deitadas no banheiro da carreira $\mathrm{I}$. 


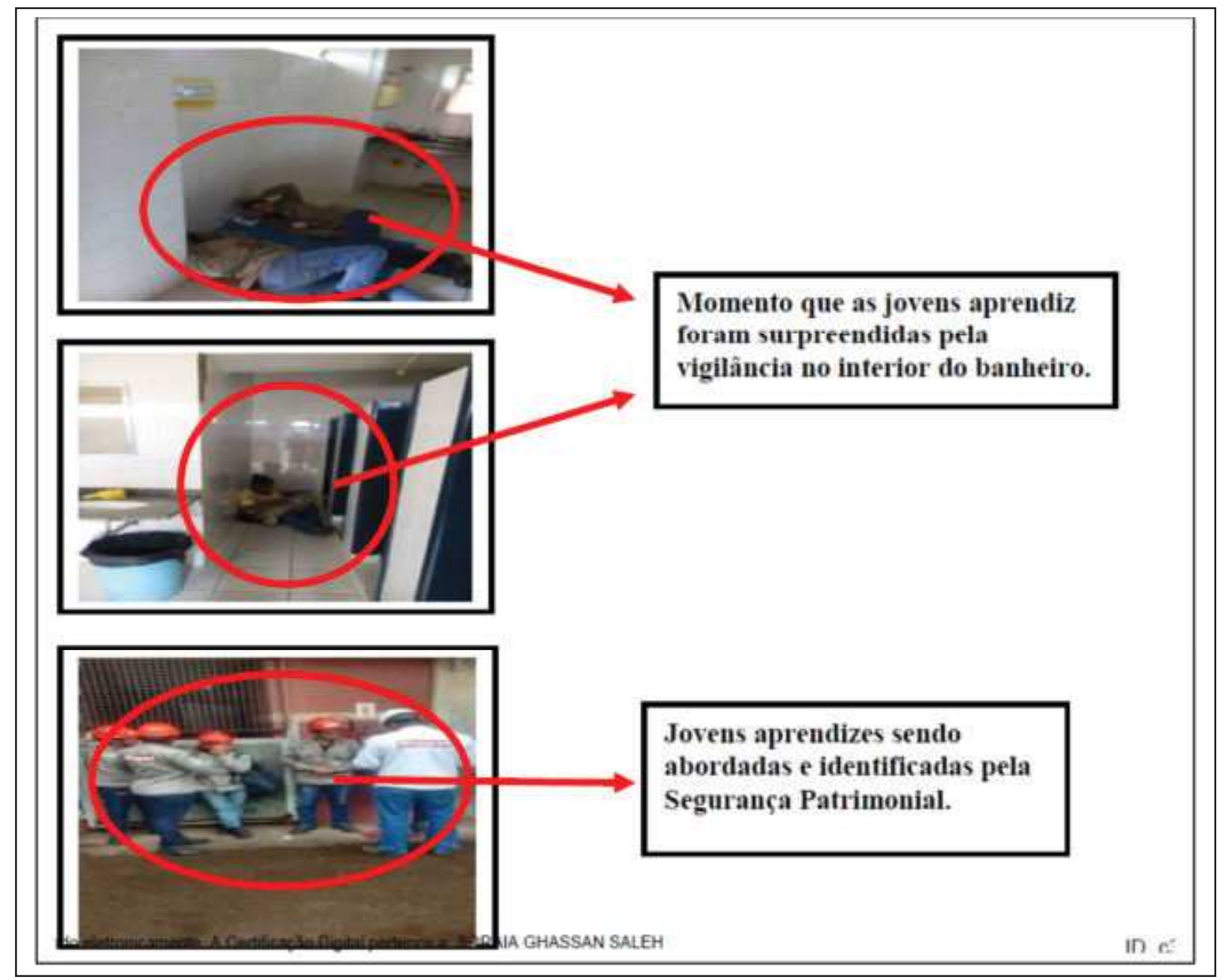

Em outro caso concreto9 a empresa conseguiu provar o ato de improbidade praticado pelo autor por ter se apropriado de valores, trazendo, além de dvd com imagens gravadas pela câmera de segurança (evidência substantiva), fotos expressas juntadas no corpo da contestação (evidência substantiva aliada a evidência demonstrativa), como se pode ver abaixo de suas alegações e imagens trazidas no corpo da defesa:

"O Reclamante sabia do circuito de segurança e olhou para a câmera enquanto preparava o ato. Acreditamos que o Reclamante executou o furto com a mão colada na parede e aguardou o exato momento em que as luzes foram apagadas acreditando que a câmera que fica acima do caixa não registraria o ato, o que facilmente se verificará através da filmagem realizada e juntada".

${ }^{9}$ Processo 00101890-95.2017.5.01.0401, disponível em http://pje.trt1.jus.br - acesso em 28/05/2021. 


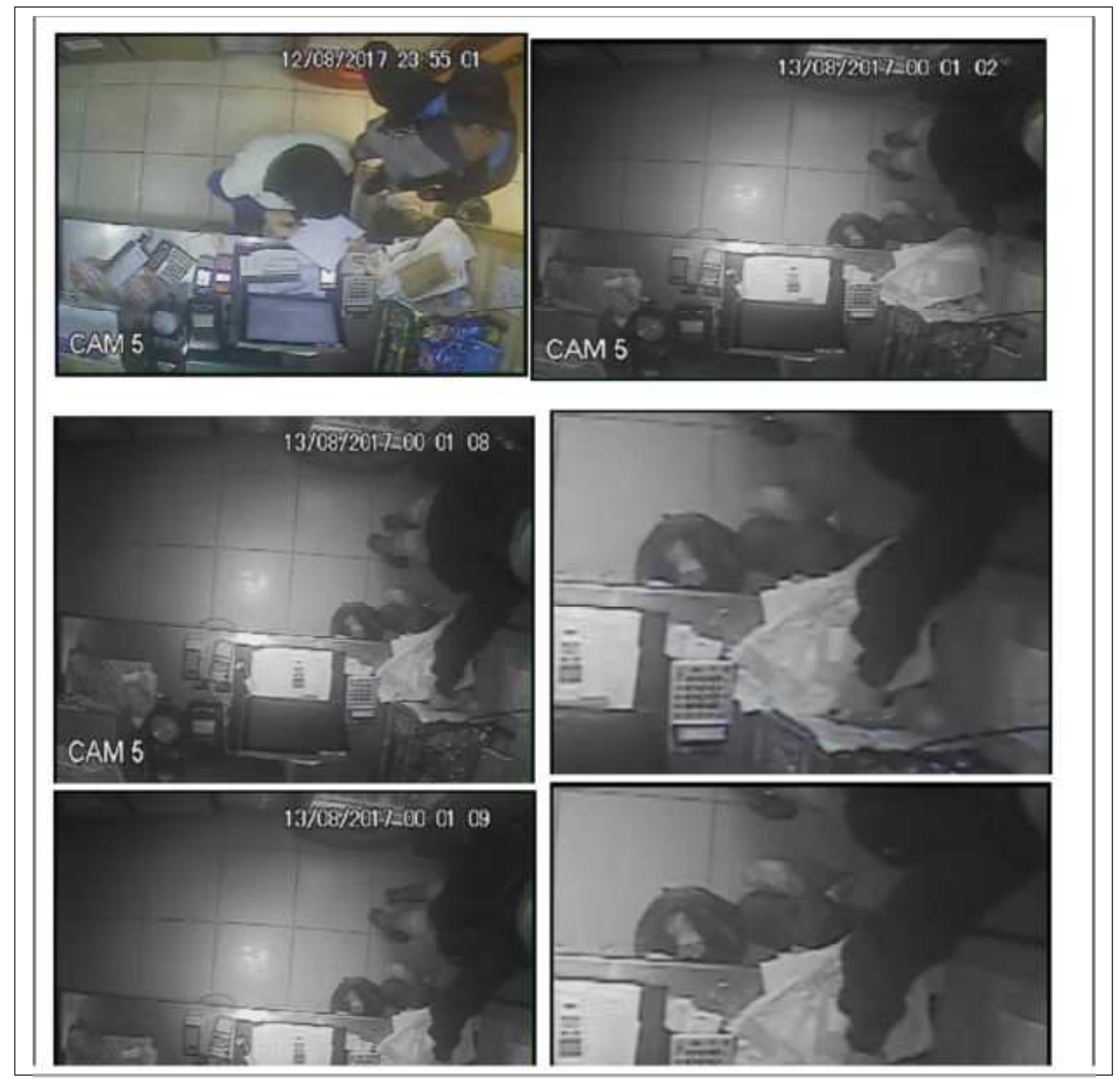

Abaixo podemos observar 10 outro processo em que a empresa utilizou-se de provas em imagens, de forma demonstrativa, através de esquemas, às quais serviram de meio de convencimento do magistrado, sobre a prática de agressão física no trabalho.

${ }^{10}$ Processo n. 0102044-16.2017.5.01.0401, disponível em http://pje.trt1.jus.br - acesso em 28/05/2021. 


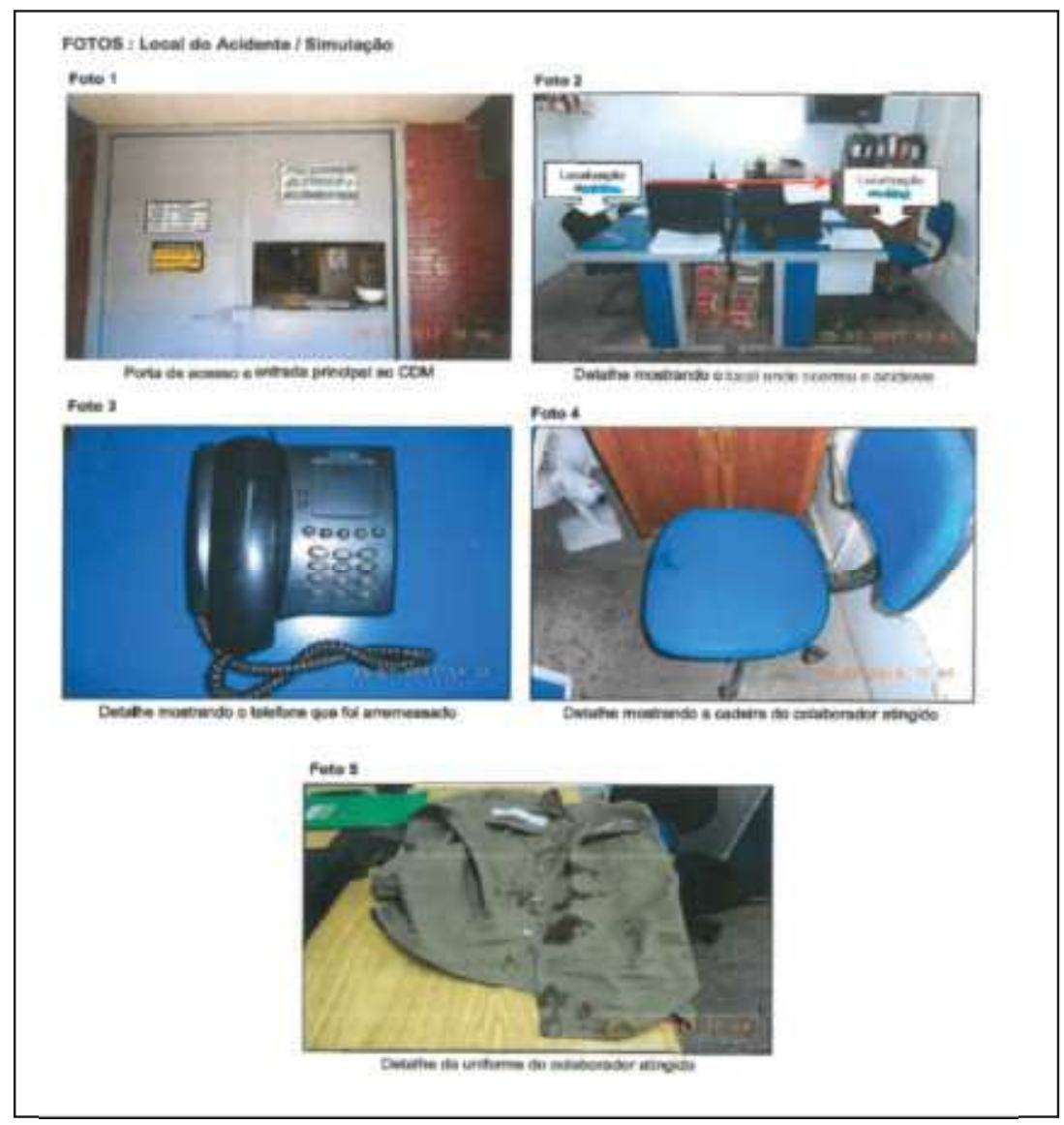

Todas essas inovações têm desaguado no mundo do processo trabalhista, acarretando em uma verdadeira revolução digital processual, para o qual o intérprete há de estar preparado. Não raras vezes, observamos provas produzidas em vídeo registradas em DVD, pen drives, links de "nuvens digitais (como o google drive)", fotografias de telas de celulares em que são abordados diálogos de whatsapp, gravações provenientes de câmeras de segurança colocadas dentro das empresas, filmagens de fatos através de câmeras de smartphones, entre outras, tudo no intento de se provar algo perante o juízo trabalhista. Diante da incidência dessas inovações, impende ressaltarmos que o Direito Processual Trabalhista é dotado de princípios específicos que vão ao encontro da fluidez, capilaridade, instantaneidade e espontaneidade da prova imagética, sofrendo influência direta da difusão generalizada de imagens, o que as tornaram elementos essenciais para a parametrização da seara jurídica trabalhista ao contexto sociocultural contemporâneo. A facilidade de incidência das provas em vídeo, todavia, tem gerado desequilíbrio, tornando difícil o aproveitamento do potencial do Direito Processual do Trabalho em incorporar a imagem.

Portanto, a modernização dos instrumentos e meios de prova tornou praticamente obrigatório o preparo dos operadores do direito para sua correta e justa abordagem, essencial para a pacificação dos conflitos decorrentes da força de trabalho e capital, no contexto da 
sociedade moderna, principalmente se consideramos que o texto positivado, no ordenamento jurídico pátrio, no tocante à temática, é bastante obsoleto, uma vez que a imagem é citada apenas uma vez em todo o ordenamento jurídico processual, ainda sendo tratada de forma como prova documental, como podemos observar da literalidade do artigo 422 caput e parágrafos do CPC:

Art. 422 Qualquer reprodução mecânica, como a fotográfica, a cinematográfica, a fonográfica ou de outra espécie, tem aptidão para fazer prova dos fatos ou das coisas representadas, se a sua conformidade com o documento original não for impugnada por aquele contra quem foi produzida. $\S 1^{\circ}$ As fotografias digitais e as extraídas da rede mundial de computadores fazem prova das imagens que reproduzem, devendo, se impugnadas, ser apresentada a respectiva autenticação eletrônica ou, não sendo possível, realizada perícia.

$\S 2^{\circ}$ Se se tratar de fotografia publicada em jornal ou revista, será exigido um exemplar original do periódico, caso impugnada a veracidade pela outra parte. $\S 3^{\circ}$ Aplica-se o disposto neste artigo à forma impressa de mensagem eletrônica.

Assim, a área trabalhista tem enfrentado habitualmente as provas modernas, decorrentes do avanço tecnológico, em um contexto de desproporcionalidade entre a velocidade de produção e sua inserção ao campo processual. Além disso, verificamos lenta evolução teórica, prática e legislativa do tema, havendo nítido vácuo legislativo por ausência de regramento ou normatividade, o que tem levado o intérprete à dificuldades na interpretação e aplicação do imagético. Ou seja, há uma tensão entre os princípios do Direito Processual do Trabalho e a normatização do tema no Brasil, o que afeta a possibilidade da utilização da prova em vídeo no país. Isso evidencia a urgente necessidade de alfabetização visual dos operadores do direito trabalhista e de todos os estudiosos do direito, além da carência de debate sobre o tema atualizando a legislação, a educação jurídica e a prática do Direito às transformações sociais tecnológicas. Tudo isto será observado e ressaltado através da análise qualitativa dos casos concretos abaixo. 


\title{
5 - CASOS CONCRETOS:
}

\section{1 - Prova em vídeo inadmitida:}

\author{
Processo 1 \\ Espécie e número do processo: rito ordinário trabalhista n. 0101519- \\ 66.2017.5.01.0067. \\ Data de ajuizamento: 27/09/2017. \\ Autor: pessoa física \\ Ré: pessoa jurídica sob a forma empresarial Ltda, especializada em transporte coletivo \\ municipal. \\ Juízo de primeira instância: $67^{\text {a }}$ Vara do Trabalho do Rio de Janeiro. \\ Data de prolação da sentença: 16/04/2019. \\ Resultado: procedência em parte. \\ Juízo de segunda instância: $9^{a}$ Turma. \\ Data de prolação do acórdão: 06/08/2019. \\ Meio de ingresso da prova em vídeo: direto (acautelamento de mídia na secretaria da \\ Vara) \\ Meio de análise da prova em vídeo: inadmitida a prova em vídeo (o vídeo não foi \\ exibido). \\ Perícia sobre o vídeo: não \\ Provimento do recurso: recurso parcialmente provido.
}

\section{Relatório do caso:}

Trata-se de demanda na qual o trabalhador, motorista de ônibus municipal, cidade do Rio de Janeiro, discordando da justa causa que lhe fora aplicada, postulou sua reversão para dispensa imotivada, com o pagamento das verbas daí advindas, alegando que não teria praticado quaisquer atos que justificassem a aplicação da pena máxima. A empresa contestou o pleito alegando, em síntese, que o autor havia praticado atos de indisciplina, desídia e mau procedimento, sustentando que, a partir de uma publicação em redes sociais, apurou-se através de investigação pelas imagens das câmeras internas dos coletivos, que o Reclamante havia "destratado passageiros, dirigido sem cinto de segurança e com a porta do coletivo aberta, deixado passageiros a pé (não parou no ponto), praticado direção perigosa e avançado sinal, em total violação as normas de transito e regulamento interno da Reclamada", o que a levou a dispensá-lo por justa causa. Importante ressaltar que o primeiro momento em que a prova produzida em vídeo veio a ser mencionada, no processo, foi na contestação, oportunidade na 
qual a empresa deixou claro que o principal argumento da defesa dependia da averiguação dos fatos gravados pelas câmeras internas do ônibus, em que trabalhava o autor, formulando pedido do acautelamento da mídia em secretaria para posterior exibição.

Nesse aspecto, cumpre destacar que a distribuição do ônus da prova sobre o término da relação de emprego é diversa daquele estabelecida pelo Código Civil11, sendo incumbência da ré a prova de que não estariam presentes os requisitos ensejadores da justa causa obreira, a teor do que dispõe a Súmula n. 212 da SDI-I do C. TST12. Assim, a ré já tinha ciência de que recaía sobre seus ombros o ônus de provar que o autor havia praticado os atos indisciplinares alegados na defesa e que as imagens gravadas eram o principal meio de prova, pois havia sido o fundamento principal utilizado para a dispensa do trabalhador. Constata-se, assim, que as imagens eram essenciais para a resolução da questão jurídica em exame.

Assim, a ré fez constar na defesa em negrito:

\begin{abstract}
"Cabe dizer que os atos que culminaram na aplicação da justa causa, podem ser comprovados com a exibição de filmagem, na qual é possível verificar todo o ocorrido, requerendo, desde já o acautelamento da mídia em secretaria, como também sua exibição em momento oportuno. (negritos originais)"
\end{abstract}

Como destacamos acima, a peça da defesa e os respectivos documentos são recebidos na audiência inaugural, momento no qual o julgador fez constar na ata de audiência:

\begin{abstract}
"O Juízo retira o sigilo da defesa e dos documentos, requerendo a patrona da ré a juntada de mídia, que deverá ser acautelada na secretaria da vara, sendo uma cópia entregue à patrona do autor, nesta oportunidade, o que é deferido pelo Juízo. Defere-se ao autor o prazo de 10 dias para manifestação sobre a defesa e documentos, inclusive sobre a mídia. A ré deverá trazer, na próxima assentada, aparelho para exibição da mídia acautelada na secretaria da Vara (negritos originais)."
\end{abstract}

Observa-se, assim, que o intérprete optou por designar nova audiência para colheita de depoimento pessoal e testemunhal, ofertando cópia da mídia à parte contrária e lhe concedendo

${ }^{11}$ Artigo 373 do CPC e 818 da CLT, praticamente idênticos: Art. 373. O ônus da prova incumbe: I - ao autor, quanto ao fato constitutivo de seu direito;II - ao réu, quanto à existência de fato impeditivo, modificativo ou extintivo do direito do autor.

${ }^{12}$ Súmula n. 212 da SDI-I do C.TST. O ônus de provar o término do contrato de trabalho, quando negados a prestação de serviço e o despedimento, é do empregador, pois o princípio da continuidade da relação de emprego constitui presunção favorável ao empregado. 
prazo para impugnação das imagens ali contidas, em respeito aos princípios do contraditório, do devido processo legal e da vedação à decisão surpresa. Todavia, imputou à reclamada o ônus de trazer aparelho para a exibição da mídia, mesmo não havendo no ordenamento jurídico norma legal que autorizasse tal conduta. Nesse ponto, observamos falha procedimental por desrespeito ao devido processo legal e identificamos o início da incidência de alguns problemas relatados na revisão da literatura, tais como desequilíbrio entre a revolução tecnológica e a receptividade da prova imagética (SHERWIN, 2011), resistência na absorção da prova em vídeo decorrente das características contrapostas da Mídia e do Direito (RICCIO et al, 2016); necessidade de atualização de conceitos legais como a argumentação jurídica e cultura jurídica (RICCIO, et al. 2016) e prova em vídeo ignorada ou supervalorizada (PORTER, 2013). Abaixo elucidaremos a continuidade dos mitos nas decisões.

O trabalhador, após analisar as imagens, impugnou-as, fazendo tabela descritiva (evidência demonstrativa, SILBEY, 2004) dos minutos da gravação, alegando que não condizia com o alegado pela ré, além de ter sustentado a ocorrência de adulteração e manipulação das imagens.

Cabe trazer a estratégia demonstrativa do autor:

Destarte que o reclamante verificou a mídia ora juntada aos autos, no entanto não encontrando esta quaisquer procedimentos do reclamante capazes de ensejar a sua justa causa:

MÍDIA:

1TE04. 14.36S REALENGO- possui data de 07-03-2017 as 14:37h, contudo conforme documento de controle de frequência do reclamante neste dia laborou até as 14:10h, logo constata-se que as imagens e horários não condizem com a verdade, seja por falha no sistema ou por adulteracão da reclamada ou ainda que havia adulteração nos controles de frequência. De sorte que em nada tais imagens demonstram uma conduta ilícita do reclamante para que este enseje a uma justa causa. Desta forma impugna tal vídeo;

1TE08-09.48- data de 07-03-2017- horário de 9:47h as 9:49h, também não trazendo aos autos qualquer conduta que enseje a sua justa causa;

1TE08-E12-8-16- data de 07-03-2017- horário 8:16h à 8:18h- também não trazendo aos autos qualquer conduta que enseje a sua justa causa;

1T.E10-10.51- data de 07-03-2017- horário de 10:53 à 11h, parado no sinal vermelho e respeitando a sinalização e parando para todos os passageiros.

1T.E12-07.46- data de 07-03-2017- informa que devido a precariedade dos ônibus o que se constata vendo as imagens, por diversas a porta do coletivo não fecha, tendo de ficar apertando os comandos por diversas vezes.

1T.E22.11.46- data de 07-03. Nada que enseje a sua demissão por justa causa; IMAGEM SOLICITADA- data de 07-03-2017, horário 15:29h até as 15:40h, horário que o autor não estava mais laborando, conforme controle de frequência juntado pela reclamada;

MíDIA EXTERNA: IMPUGNA tal vídeo, haja vista que não há data, identificação do motorista, sendo certo não ser o reclamante, assim como tratar-se de imagem postada em redes sociais sem qualquer ligação ao autor, bem como se a ré possui gravação em vídeos do seu coletivo, por qual motivo 
não fez a juntada oficial de tal ocorrência. Logo impugnando tais imagens, vez não possuir qualquer ligação com o reclamante e com a sua demissão por justa causa (negritos e sublinhados acrescidos).

Dos destaques da transcrição acima podemos observar que o trabalhador, além de ter negado a prática de atos que justificassem a justa causa, alegou também adulteração das imagens, horário da gravação não compatível com sua jornada e, em alguns momentos, se tratar de outro motorista. Assim, houve impugnação específica sobre a veracidade do conteúdo gravado, o que, inicialmente, demonstra a necessidade da realização de perícia sobre a mídia apresentada. Assim, foi concedido prazo para a empresa se manifestar sobre a impugnação apresentada - tréplica - tendo esta reiterado que o autor teria praticado os atos que justificavam a aplicação da justa causa o que, segunda ela, seria confirmado pela exibição da mídia em audiência.

Entretanto, em audiência de instrução, o julgador ressaltou que a ré pretendia a exibição de mídia para comprovar a tese narrada na contestação e que esta deveria comparecer em juízo portando "aparelho para exibição da mídia" como determinado na audiência anterior, registrando que esta não o teria feito. Ou seja, a resistência ao uso da prova em vídeo é reiterada, sendo flagrante a presença dos demais problemas acima mencionados, como o desequilíbrio tecnológico e a necessidade de atualização de conceitos legais, entre outros.

Assim, registrou-se em ata de audiência de instrução:

Ratifica a ré que pretende a exibicão de mídia para comprovar a tese narrada na contestação, reportando-se a ata anterior. Entretanto, ciente de que deveria comparecer em juízo portando "aparelho para exibicão da mídia" como consta na ata anterior, informa que não possui o aparelho nesta oportunidade.

Finda a instrução, o processo foi à conclusão para a prolação da sentença a qual destacamos as partes no tocante à prova produzida em vídeo.

\section{"DA DISPENSA}

Impugnou o autor as alegações da ré, visto que os vídeos gravados não condizem com os motivos citados pela ré.

Na assentada de id ec41ef9, ratificou a ré que pretendia a exibição de mídia para comprovar a tese narrada na contestação, reportando-se a ata anterior. Entretanto, ciente de que deveria comparecer em juízo portando "aparelho como consta na ata anterior (id 2d0e935 - Pág. 1), informa que não possui para exibição da mídia" o aparelho nesta oportunidade. 
A ré atraiu para si o ônus da prova quanto os motivos ensejadores para a dispensa imotivada do autor, mormente quando se comprometeu em ata na exibição de mídia, quedando-se inerte, perdendo assim a prova.

Não há como comprovar que a mídia acautelada na secretaria e aquela entregue ao autor possuem o mesmo conteúdo. Sendo, assim, não se desincumbindo do ônus da prova, reverto a justa causa em dispensa imotivada na data 10/3/2017 conforme TRCT assinado pelo autor. São devidas as seguintes verbas referente ao período contratual 14/6/2016 a 10/3/2017: - Aviso prévio 30 dias; férias proporcionais 9/12 acrescidas do terço constitucional (com a projeção do aviso prévio); $13^{\circ}$ salário proporcional 4/12. (negritos acrescidos)"

Percebemos, assim, que a decisão fez menção expressa à prova em vídeo a qual foi determinante para o resultado do julgamento, pois a sua inadmissão impossibilitou a ré de se desincumbir de seu ônus processual de provar a ocorrência dos fatos ensejadores da justa causa, o que a fez ser condenada a pagar as verbas decorrentes de uma dispensa imotivada, às quais são bem maiores em comparação aos valores de uma justa causa do trabalhador. Observamos, ainda, claramente, a reiteração de todos os problemas ocorridos nas decisões realizadas nas audiências. Houve um desequilíbrio entre o avanço da tecnologia e o Direito (SHERWIN, 2011) e nítida resistência em se utilizar da prova imagética (RICCIO, et al. 2016), falha procedimental, desrespeito ao devido processo legal e necessidade de atualização de conceitos legais (RICCIO, et al. 2016) pelo fato de a decisão entender ser de obrigação da empresa trazer para o judiciário aparelho necessário para exibição da mídia, imputando-lhe ônus processual que a lei não determina, não sequer chegando a assistir às imagens para prolatar sua sentença. Isso demonstra a ocorrência de lacunas na interpretação do novo tipo de prova, o que poderia ser suprido pela alfabetização visual (SHERWIN, 2019).

Observa-se, ainda, que a resistência na absorção da prova em vídeo foi tão intensa que, mesmo tendo dúvida acerca do conteúdo e veracidade das imagens, entregues ao autor e aquelas acauteladas em secretaria, a decisão foi no sentido de não haver prova das alegações da ré, dando procedência ao pleito do trabalhador sem determinar a realização de prova pericial. Aqui se desprestigiou o princípio da primazia da realidade e da busca da verdade real (LEITE, 2018), pois havendo dúvida sobre a veracidade das imagens, tendo o autor procedido a sua impugnação, necessária seria a realização de perícia para averiguar o conteúdo das imagens, no objetivo de se proferir decisão justa e em harmonia à realidade do ocorrido.

A pausa mental sobre a admissão da prova teria sido bastante adequada ao momento, onde o intérprete, com a prudência e a cautela devida poderia ter repensado sobre a essencialidade da prova em vídeo a qual foi totalmente ignorada (PORTER, 2013). O devido processo legal também foi desprivilegiado, uma vez que foi distribuído ônus processual de 
forma não prevista em lei, sendo que a exibição da mídia poderia ter sido realizada pelo computador do próprio judiciário, não havendo razões para impedir que a as imagens fossem assistidas ou exibidas por falta de aparelho não trazido pela empresa. Observamos, portanto, a expressa necessidade de alfabetização visual (SHERWIN, 2011) pela incidência dos seguintes problemas na sentença de primeiro grau, segundo a tabela de parâmetros qualitativos n.1: falha procedimental por desrespeito ao devido processo legal; desequilíbrio entre a revolução tecnológica e a receptividade da prova imagética (SHERWIN, 2011), resistência na absorção da prova em vídeo decorrente das características contrapostas da Mídia e do Direito (RICCIO, 2016); necessidade de atualização de conceitos legais como a argumentação jurídica e cultura jurídica (RICCIO, et al. 2016) e prova em vídeo ignorada ou supervalorizada (PORTER, 2013).

A Ré, então, interpôs recurso ordinário para apreciação do segundo grau de jurisdição, o qual, entre outros argumentos, suscitou preliminar de cerceio de defesa pela não apreciação das imagens pelo Juízo de piso, justificando a ausência do aparelho para exibição da mídia, ressaltando que a magistrada poderia ter "lançado mão da mídia a qualquer tempo", não permitindo a exibição e não analisando a mídia entregue.

Cabe trazer a referida preliminar em sua literalidade:

\begin{abstract}
"DA PRELIMINAR
DO CERCEIO DE DEFESA

O Recorrente, em primeira assentada, acautelou uma mídia no cartório, bem como entregou outra cópia ao Demandante, a fim de comprovar as reais razões as quais motivaram sua dispensa por justa causa. Ocorre que no dia da realização da assentada, o aparelho para a reprodução da mídia encontrava-se em outra audiência, a qual também se fazia necessária a exibição de mídia e que se encontrava demasiadamente atrasada, não sendo deferido agendamento de nova data para tal exibição (negritos acrescidos).

Entretanto, como o Obreiro já havia se manifestado sobre os vídeos constantes na mídia acautelada, inclusive de forma individual, vez que a mídia possui 8 vídeos, não havendo qualquer questionamento sobre a licitude ou validade da prova, além do fato de o Magistrado poder lançar mão da mídia a qualquer tempo, assim não o fez, não permitindo a exibição posteriormente, tampouco analisando a mídia a ele entregue."
\end{abstract}

Há de se ressaltar, nesse ponto, que a ré apresentou, no corpo do recurso ordinário, links em que as imagens poderiam ser assistidas, na seguinte manifestação, na peça recursal:

A fim de que se facilite a visualização dos vídeos os quais motivaram a dispensa motivada do Obreiro, estando os mesmos, repita-se, em poder tanto do Reclamante quanto do Juízo a quo, apresenta-se abaixo os links para que os mesmos sejam assistidos: 
https://drive.google.com/file/d/1th83C2Gh-8-

zkW0GOIADHqKfIjhuaW8u/view?usp=sharing

https://drive.google.com/open?id=1f0o12vj-coc13-X-QiI_oi8hJNz40O

Hhttps://drive.google.com/open?id=118kA_PNJleGqIxlQVnUL2o1gYtiP7iC j

https://drive.google.com/open?id=1LjCYyY2qJy_mLFxKbyFroYsWrTu5C EZ1

https://drive.google.com/open?id=18aeBBoYYIjb4ixq7syEhNX29FaoH2A8 $\underline{\mathrm{h}}$

Ao clicar em algum dos links acima pode-se assistir facilmente às imagens gravadas, às quais, segundo a empresa, comprovariam os atos ímprobos do motorista (como avanço de sinal vermelho, direção sem cinto de segurança, com a porta aberta e passageiros em pé) o que nós realizamos na presente data (21/05/2020), sendo que colacionamos abaixo alguns prints das filmagens para melhor elucidação do ocorrido.
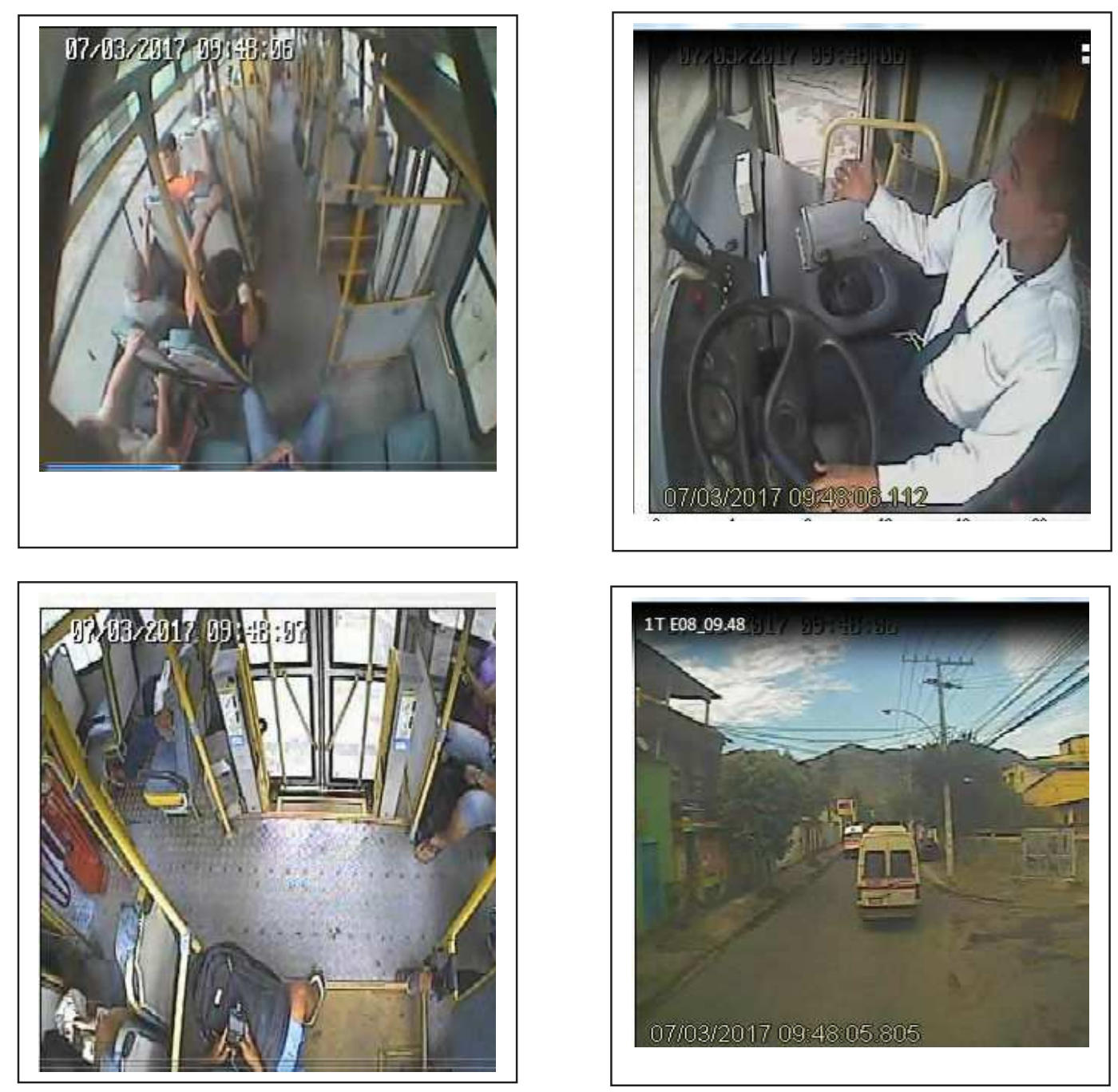
Mesmo diante dessa facilidade, o segundo grau de jurisdição negou provimento ao recurso ordinário interposto pela Ré (o qual prevaleceu em trânsito em julgado em 02/09/2019), rejeitando a preliminar de cerceio de defesa, meramente repetindo os argumentos da decisão de primeiro grau ressaltando que restou inviabilizada a reprodução da mídia, por culpa exclusiva da empresa, a qual não teria permitido ao Judiciário ter acesso ao seu teor. Aqui repete-se a incidência dos mesmos problemas observados na revisão de literatura, indicados na decisão de primeiro grau, restando claras a resistência (SHERWIN, 2011), desorganização administrativa, desrespeito aos princípios do devido processo legal, primazia da realidade e busca da verdade real (LEITE, 2018), prova imagética ignorada (PORTER, 2013) e desequilíbrio entre o avanço tecnológico (SHERWIN, 2011) e a receptividade da prova imagética por diferenças entre a Mídia e o Direito (RICCIO, et al. 2016).

Cabe trazer a literalidade da fundamentação do referido acórdão:

Não assiste razão à recorrente.
Com efeito, não custa enfatizar que a justa causa para ser chancelada em Juízo
necessita ser robustamente comprovada, de modo que não permaneça
qualquer dúvida quanto à conduta atribuída ao trabalhador. Não hipótese dos
autos foram várias as acusações que pesaram sobre o reclamante, porém, não
há comprovação cabal de quaisquer delas. A recorrente não aponta para
nenhuma outra prova senão as imagens constantes da debatida mídia,
cuja reprodução, frise-se, restou inviabilizada por culpa exclusiva da
própria ré, não permitindo ao Juízo ter acesso ao seu teor. Ademais, a
reclamada, embora em sua peça de bloqueio afirme ter instaurado uma
investigação interna, não traz aos autos qualquer registro formal do aludido
procedimento. Se não bastasse, nota-se que a reclamada tenta, em sede
recursal, indicar novos meios de prova, já que em momento algum da fase
instrutória fez referência a qualquer "link" de internet que desse acesso ao teor
da mídia acautelada. Em suma, não há documentos no autos que
comprovem, de forma inequívoca, a participação do reclamante nas
ocorrências retratadas, sendo certo, vale ressaltar, que não fora
produzida prova testemunhal. Não há, assim, qualquer reparo a ser feito na
sentença, no particular. Nego provimento (negritos acrescidos)."

Percebemos, assim, que a lide resumia-se a controvérsia fática, cingindo-se à averiguação de supostos atos de extrema gravidade, imputados ao trabalhador, dentro do local e no horário de trabalho, os quais seriam suficientes a justificar sua dispensa por justa causa, conforme previsto no artigo 482 da CLT, pela prática de ato de indisciplina, desídia, mau procedimento, entre outros. Era de suma importância para a prolação de uma decisão justa, equânime, amparada pela busca da verdade e em consonância à primazia da realidade, a análise detida das imagens trazidas aos autos, às quais revelavam-se essenciais ao deslinde da questão central da controvérsia, cabendo ressaltar que o lastro probatório não continha outras provas, tais como as documentais ou testemunhais. Mesmo diante da visível essencialidade da prova 
produzida pela parte Ré, suas imagens trazidas em mídia, não chegaram a ser analisadas, em sede de primeiro e segundo graus de jurisdição, os quais entenderam ser ônus processual da empresa trazer em audiência aparelho adequado para exibição da mídia trazida.

Verificamos, dessa forma, que houve extrema resistência de utilização da prova em vídeo, tendo sido colocados obstáculos intransponíveis para que os fatos ali relatados pudessem interferir no convencimento do julgador, o que vai ao encontro da tese de que o Direito e seus intérpretes se pautam, ainda, pela palavra escrita, pela rigidez das formas e apego ao racionalismo exacerbado, em contrassenso à revolução tecnológica, ora experimentada pela sociedade, necessitando de alfabetização visual.

Respondendo às tabelas de parâmetros qualitativos temos:

TABELA DE PARÂMETROS QUALITATIVOS N. 1 - PROBLEMAS OBSERVADOS NA REVISÃO DE LITERATURA:

\begin{tabular}{|l|l|l|}
\hline & SENTENÇAS & ACÓRDÃOS \\
\hline $\begin{array}{l}\text { a) desequilíbrio da } \\
\text { tecnologia e o } \\
\text { Direito. }\end{array}$ & $\begin{array}{l}\text { Sim, pela resistência na utilização da } \\
\text { prova em vídeo, ausência de aparelho } \\
\text { para apresentação da mídia. }\end{array}$ & $\begin{array}{l}\text { Sim, pela resistência na } \\
\text { utilização da prova em vídeo, } \\
\text { ausência de aparelho para } \\
\text { apresentação da mídia. }\end{array}$ \\
\hline $\begin{array}{l}\text { b) resistência na } \\
\text { absorção da prova } \\
\text { em vídeo. }\end{array}$ & $\begin{array}{l}\text { Sim, intensa resistência na utilização } \\
\text { da prova em vídeo, uma vez que as } \\
\text { imagens sequer foram visualizadas, } \\
\text { mesmo diante de grande facilidade. }\end{array}$ & $\begin{array}{l}\text { Sim, intensa resistência na } \\
\text { utilização da prova em vídeo, } \\
\text { uma vez que as imagens sequer } \\
\text { foram visualizadas, mesmo } \\
\text { diante de grande facilidade. }\end{array}$ \\
\hline $\begin{array}{l}\text { c) desorganização } \\
\text { administrativa. }\end{array}$ & $\begin{array}{l}\text { Sim, falha no procedimento de não } \\
\text { visualização das imagens, imputação } \\
\text { de ônus de trazer aparelho ao autor } \\
\text { sem previsão legal. }\end{array}$ & $\begin{array}{l}\text { Sim, falha no procedimento de } \\
\text { não visualização das imagens, } \\
\text { imputação de ônus de trazer } \\
\text { aparelho ao autor sem previsão } \\
\text { legal. }\end{array}$ \\
\hline
\end{tabular}




\begin{tabular}{|c|c|c|}
\hline $\begin{array}{l}\text { d) a imagem diz } \\
\text { por si. }\end{array}$ & $X$ & $\mathrm{X}$ \\
\hline $\begin{array}{l}\text { e) janela pra } \\
\text { realidade, } \\
\text { imparcialidade do } \\
\text { vídeo, testemunha } \\
\text { ocular, } \\
\text { testemunha } \\
\text { silenciosa. }\end{array}$ & $X$ & $\mathrm{X}$ \\
\hline $\begin{array}{l}\text { f) frágil } \\
\text { interpretação } \\
\text { cruzada do filme. }\end{array}$ & $\mathrm{X}$ & $\mathrm{X}$ \\
\hline $\begin{array}{l}\text { g) iliberalismo } \\
\text { cognitivo e } \\
\text { influência da } \\
\text { emoção. }\end{array}$ & $\mathrm{X}$ & $\mathrm{X}$ \\
\hline $\begin{array}{l}\text { h) necessidade de } \\
\text { atualização de } \\
\text { conceitos legais. }\end{array}$ & $\begin{array}{l}\sqrt{ } \\
\text { Sim, a prova em vídeo foi totalmente } \\
\text { ignorada pelos intérpretes. }\end{array}$ & $\begin{array}{l}\text { l } \\
\text { Sim, a prova em vídeo foi } \\
\text { totalmente ignorada pelos } \\
\text { intérpretes }\end{array}$ \\
\hline
\end{tabular}

TABELA DE PARÂMETROS QUALITATIVOS N. 2: PONTOS RELEVANTES ABORDADOS.

\begin{tabular}{|c|c|}
\hline PARÂMETROS: & \\
\hline $\begin{array}{l}1 \text { - o juiz de primeiro grau ou o } \\
\text { desembargador, de fato, assistiram à } \\
\text { prova produzida em vídeo e em que } \\
\text { momento processual, em mesa de } \\
\text { audiências ou fora dela? }\end{array}$ & $\begin{array}{l}\text { As imagens não foram assistidas tanto pelo juiz } \\
\text { de primeiro grau, quanto pelo relator e } \\
\text { desembargados da turma de segundo grau de } \\
\text { jurisdição. }\end{array}$ \\
\hline $\begin{array}{l}2 \text { - as imagens foram relevantes para a } \\
\text { solução da controvérsia jurídica tendo }\end{array}$ & $\begin{array}{l}\text { As imagens foram relevantes no sentido de que a } \\
\text { impossibilidade de sua visualização fez com que } \\
\text { a ré não se desincumbisse de seu ônus processual, }\end{array}$ \\
\hline
\end{tabular}




\begin{tabular}{|c|c|}
\hline $\begin{array}{l}\text { sido mencionadas na fundamentação das } \\
\text { decisões? }\end{array}$ & $\begin{array}{l}\text { vindo a ser condenada no processo, em virtude } \\
\text { disto. A ausência de possibilidade de } \\
\text { visualização foi imputada à ré, sem previsão } \\
\text { legal, tendo sido tal fato utilizado expressamente } \\
\text { nas decisões de primeiro e segundo grau. }\end{array}$ \\
\hline $\begin{array}{l}\text { 3- qual o embasamento jurídico utilizado } \\
\text { pelo magistrado, subsunção a texto } \\
\text { expresso de lei ou prevalência de } \\
\text { princípios (mandamentos de otimização } \\
\text { prima facie); houve respeito aos } \\
\text { princípios do devido processo legal, } \\
\text { contraditório e vedação à decisão } \\
\text { surpresa (interdisciplinaridade com o } \\
\text { Processo Civil)? }\end{array}$ & $\begin{array}{l}\text { Não houve aplicação de texto de lei, tampouco de } \\
\text { princípios. A entrega de cópia da mídia à parte } \\
\text { contrária e ao juízo demonstram respeito aos } \\
\text { princípios do contraditório e vedação à decisão } \\
\text { surpresa. Houve parcial violação ao devido } \\
\text { processo legal pela distribuição de ônus da prova } \\
\text { (apresentação de aparelho) não previsto em lei. }\end{array}$ \\
\hline $\begin{array}{l}4-\text { o conteúdo das imagens foi } \\
\text { expressamente impugnado por alguma } \\
\text { parte, de modo a se tornar necessária a } \\
\text { produção de prova pericial do vídeo } \\
\text { apresentado? }\end{array}$ & $\begin{array}{l}\text { O conteúdo das imagens foi expressamente } \\
\text { impugnado pelo autor que alegou, inclusive, } \\
\text { adulteração, não tendo sido determinado pelos } \\
\text { magistrados e desembargadores a realização de } \\
\text { prova pericial. }\end{array}$ \\
\hline $\begin{array}{l}5 \text { - se as demais provas dos autos foram } \\
\text { levadas em confronto às imagens } \\
\text { analisadas? }\end{array}$ & $\begin{array}{l}\text { Não houve produção de outras provas no } \\
\text { processo, sendo as imagens o único meio de } \\
\text { prova utilizado. }\end{array}$ \\
\hline $\begin{array}{l}6 \text { - restou evidenciada a necessidade de } \\
\text { alfabetização visual? }\end{array}$ & $\begin{array}{l}\text { A necessidade de alfabetização visual restou } \\
\text { plenamente verificada, pela forte resistência dos } \\
\text { intérpretes de se valerem das imagens trazidas } \\
\text { aos autos. }\end{array}$ \\
\hline Soluções propostas: & $\begin{array}{l}\text { Procedimento de admissão da prova em vídeo } \\
\text { poderia ser realizado de forma mais cautelosa, } \\
\text { com a pausa mental e visualização de possíveis } \\
\text { resultados dissonantes da verdade real. }\end{array}$ \\
\hline
\end{tabular}

5.2 - Decisão mantida em $2^{\circ}$ grau de jurisdição: 


\section{Processo N. 2}

Espécie e número do processo: rito ordinário trabalhista n. 010045548.2017.5.01.0058.

Data de ajuizamento: 30/03/2017.

Autor: pessoa física, cargo técnico de enfermagem.

Ré: pessoa jurídica especializada em serviços hospitalares.

Juízo de primeira instância: $58^{\text {a }}$ Vara do Trabalho do Rio de Janeiro.

Data de prolação da sentença: 13/03/2018.

Resultado: procedência em parte.

Juízo de segunda instância: $6^{\text {a }}$ Turma.

Data de prolação do acórdão: 21/05/2019.

Resultado do julgamento em segunda instância: negado provimento.

Meio de ingresso da prova em vídeo: direto (acautelamento de mídia na secretaria da Vara)

Meio de análise da prova em vídeo: dvd assistido fora da audiência.

Perícia sobre o vídeo: não

Relatório e comentários sobre o caso:

O referido processo, ajuizado em 30/03/2017 e transitado em julgado em 03/06/2020, teve solução da lide com influência expressa da prova em vídeo.

A controvérsia cinge-se ao fato de ter ocorrido a queda de paciente da cama de UTI o qual se encontrava sob a responsabilidade da autora, técnica de enfermagem contratada pela ré.

A autora, discordando da justa causa aplicada, alegou que estava sobrecarregada, cuidando de nove pacientes, no dia do ocorrido, e que, na realidade, o paciente, que estava sob seus cuidados, havia se atirado da cama, vindo a cair no chão, mesmo com a grade da cama levantada. Alegou, ainda, que no momento da queda encontrava-se fazendo os cálculos dos remédios do paciente, e que não teria, assim, praticado qualquer ato que pudesse ser configurado como justa causa obreira.

A ré, por seu turno, rebateu o pleito sustentando que a tese da parte autora não condizia com a realidade, uma vez que a câmera de segurança do setor havia registrado conduta negligente e reprovável por parte da trabalhadora que havia permanecido no celular, durante o trabalho, à beira da cama do paciente, que veio a cair por falta de auxílio da parte desta. 
Assim afirmou a ré na peça da defesa:

\begin{abstract}
"Segundo a Ré, as referidas gravacões deixavam claro que a Autora encontrava-se "sentada em frente ao leito do paciente em questão e por volta das 23:18:04 pega o celular e começa a utilizá-lo, neste tempo o paciente começa a apresentar certa agitação, por volta das 23:21:30 e mesmo assim a reclamante nem sequer levanta a cabeça para verificar, continuando a manusear seu celular, assim no horário de 23:22:13 o paciente cai de sua cama, quando a reclamante que escutou o barulho, como todos os outros que estavam em procedimentos. (Grifos e negritos acrescidos)"
\end{abstract}

A ré trouxe aos autos DVD com imagens de câmera interna de segurança do hospital, na data da audiência inaugural, junto da contestação, tendo sido fornecidas cópias para o reclamante e para o Juízo, a qual foi acautelado na secretaria da Vara do Trabalho, tendo sido respeitados, assim, os princípios do devido processo legal, contraditório e vedação à decisão surpresa. A autora procedeu à impugnação da peça da defesa alegando ausência de proibição de uso de celulares em serviço, bem como sobrecarga de trabalho, não procedendo à impugnação da veracidade do conteúdo das imagens, o que tornou desnecessária a realização de prova pericial, não se verificando, assim, falha procedimental.

A magistrada que presidiu as audiências procedeu à lavratura de sentença a qual trouxe os seguintes tópicos cujo destaque ora se impõe a transcrição:

\title{
DA JUSTA CAUSA
}

Pretende a Autora desconstituir a justa causa que lhe foi aplicada, com fulcro no Art. 482, alíneas "e", da CLT, sustentando, em síntese, que não cometeu nenhum ato que justificasse a aplicação da justa causa.

O Réu, em contrapartida, alega que aplicou a justa causa por desídia, após ter apurado incidente ocorrido na UTI, com paciente acamado que teria se agitado e caído de seu leito quando estava sob os cuidados profissionais da Autora.

A imagem colhida pela câmera de segurança do setor (conteúdo do DVD) mostra a Reclamante mexendo em seu celular (assistindo vídeos) por vários minutos enquanto o paciente demonstrava agitação, sem qualquer atitude da demandante, exatamente pela sua falta de atenção. Somente após a queda do paciente do leito, que poderia ter sido evitada, a demandante largou o telefone celular para efetuar o socorro.

Além do exposto acima, em depoimento pessoal, a Demandante confessou que estava mexendo no celular e que somente ouviu o barulho quando o paciente caiu, sob o argumento de que estaria "fazendo os cálculos do paciente". Ocorre que, conforme verificado no conteúdo do DVD apresentado, a autora assistia vídeos no momento da queda do paciente, não sendo verdadeira a narrativa quanto aos "cálculos do paciente". 
No que tange ao relato da enfermeira ANA PAULA GAMA no documento id 23730be (que supostamente afasta a responsabilidade da parte autora pela ocorrência), este resta afastado por ausência de credibilidade, uma vez que, quando ouvida como testemunha, afirmou não saber onde a Autora estava no momento da queda.

No Direito do Trabalho, como no Direito Comum, o inadimplemento voluntário de uma das partes produz a resolução do contrato. Mas, nestes, há diferenças marcantes, que imprimem ao instituto uma configuração diversa.

Enquanto no Direito Comum o contratante responde por simples culpa, no Direito do Trabalho o inadimplemento capaz de provocar a resolução do contrato deve assumir a figura da "justa causa", ou seja, de um motivo que torne indesejável o prosseguimento da relação.

Como a doutrina já estabelece, trata-se de um ato doloso ou gravemente culposo, no qual a confiança e a boa-fé desaparecem, prejudicando, assim, a continuação da relação de emprego.

Para caracterização da justa causa, deverão ser observadas certas limitações, tais como: o fato não poderá extravasar os contornos fixados no art. 482 da CLT (capitulação legal); a reação da empresa, rescindindo o contrato, deve ser imediata, o que não afasta o decurso de tempo razoável para reflexão e apuração, viável com a complexidade da empresa; gravidade tal que impossibilite a normal continuação do vínculo; há penas leves para as faltas leves, que não justificam o despedimento; inexistência de perdão tácito ou expresso; que o fato seja efetivamente o determinante da rescisão (relação causa e efeito), não podendo ser substituído, fatos posteriores, mesmo graves, em princípio não influenciam (salvo se estes eram desconhecidos, quando da comunicação, em cuja hipótese deverá haver manifestação expressa do empregador; haja repercussão na vida da empresa ou tenha sido ferida cláusula do contrato; a regra não é absoluta, pois a CLT acolheu algumas hipóteses taxativas que caracterizam exceção ao princípio; exemplo: incontinência de conduta; que o fato não tenha sido punido; apreciação das condições objetivas do caso, da personalidade do empregado, do seu passado na empresa.

A alegação de justa causa para despedimento do empregado deve ser exuberantemente provada pelo empregador (art. 818 da CLT c/c art. 769 da CLT c/c art. 373, II do CPC/2015) sob pena da Justiça do Trabalho concluir pela dispensa injustificada.

No caso em tela, o empregador aplicou a justa causa ao Demandante, com fulcro no Art. 482, "e", da CLT, após apurar que a Reclamante teve comportamento inadequado e não interviu para evitar incidente ocorrido no CTI com paciente que estava sob seus cuidados profissionais naquele momento.

Diante de todo o exposto, mantenho a justa causa aplicada em 24/11/2016, e, em razão deste fato, julgo improcedente o pleito de nulidade da dispensa por justa causa; aviso prévio indenizado e indenização compensatória de $40 \%$ do FGTS, bem como os pedidos de entrega das guias para saque do FGTS e do seguro-desemprego.

Julgo improcedentes, ainda, os pedidos de pagamento do $13^{\circ}$ salário proporcional do último exercício laborado e das férias proporcionais $+1 / 3$ do 
último período aquisitivo, em razão do exposto, respectivamente, no art. $3^{\circ} \mathrm{da}$ Lei 4.090/62 c/c art. $7^{\circ}$ do Decreto 57.155/65 e na Súmula 171 do TST. Nesse sentido a jurisprudência:

DISPENSA POR JUSTA CAUSA. PAGAMENTO DE FÉRIAS E $13^{\circ}$ SALÁRIO PROPORCIONAIS. NÃO-CABIMENTO. O colendo TST, em 21.11.03, não obstante adequar a Súmula n. 171 aos termos da Convenção n. 132 da OIT no que tange às demais hipóteses de rescisão contratual, houve por bem ressalvar a hipótese em debate nestes autos, conforme se observa da novel redação da aludida cristalização, segundo a qual 'Salvo na hipótese de dispensa do empregado por justa causa, a extinção do contrato de trabalho sujeita o empregador ao pagamento da remuneração das férias proporcionais, ainda que incompleto o período aquisitivo de 12 (doze) meses'. Assim, acorde com a doutrina e a jurisprudência majoritárias, não são devidos o $13^{\circ}$ salário e as férias proporcionais em caso de dispensa por justa causa. Recurso ao qual se nega provimento. TRT-MT - Processo $\mathrm{n}^{\mathrm{o}}$ 00156.2008.036.23.00.0 Relator: Desembargador Roberto Benatar. DJE/TRT23: 27/08/2008.

Com base na modalidade rescisória (justa causa), o saldo de salário, as férias vencidas $+1 / 3$, adicional de insalubridade e horas extras foram computados no TRCT de fls. 144/145, estando, portanto, quitadas estas parcelas.

Percebemos, claramente, que o vídeo foi efetivamente assistido pela magistrada de primeiro grau, em momento posterior à audiência de instrução, ou seja, de forma não concomitante ou presencial em relação às partes e advogados. A decisão fez expressa menção aos fatos assistidos no vídeo, com indicação específica do que ali observado, usando expressões que não deixam dúvidas sobre sua relevância e influência direta, ou seja, os elementos imagéticos foram o principal argumento da fundamentação, tendo sido totalmente determinantes para o resultado do julgamento. Observamos, também, que a sentença afirma a origem da gravação (imagem colhida pela câmera de segurança do setor, conteúdo do DVD), indica fato específico da trabalhadora mexendo em seu celular ao assistir vídeos por vários minutos enquanto o paciente demonstrava agitação, apontando a conduta da obreira até o final dos fatos assistidos.

Nesse ponto não observamos a incidência de problemas ou mitos, como resistência ao uso da prova imagética (RICCIO et al. 2016), decisão precipitada por análise superficial (FEIGENSON, 2014) ou prova em vídeo ignorada ou supervalorizada (PORTER, 2013), tendo sido proferida decisão após análise equânime das imagens. Nesse mesmo sentido, verificamos que a intérprete realizou o confronto da prova em vídeo (interpretação cruzada do filme, SILBEY, 2004) com a prova documental, ao afastar a veracidade do relato da enfermeira em relatório do trabalho por não estar presente no momento do ocorrido, e a prova oral, ao transcrever e fundamentar a confissão da autora sobre o uso do celular, ressaltando que não mereciam prosperar seus argumentos no sentido de que o uso do celular seria para a realização 
dos cálculos dos remédios paciente, pois as imagens haviam deixado claro que a trabalhadora estaria, na realidade, assistindo vídeos no momento do ocorrido. Mais uma vez a decisão mostrou-se rica em detalhes do que assistido na prova midiática. Podemos observar, também, que foram efetivamente respeitados os princípios constitucionais do devido processo legal, contraditório e ampla defesa, os princípios processuais trabalhistas da primazia da realidade e busca da verdade real, além dos princípios processuais cíveis, aplicados de forma supletiva, da vedação à decisão surpresa e primazia do julgamento de mérito pela ampla possibilidade ofertada de manifestação sobre as imagens, evidenciando-se, ainda, a desnecessidade de produção de prova pericial para averiguação de eventual falsidade ou manipulação.

A trabalhadora interpôs recurso ordinário, tendo sido remetido o processo ao segundo grau de jurisdição, sem a remessa do DVD, com as referidas imagens, o que resultou na retirada do feito de pauta e solicitação de remessa da mídia acautelada para a E. $6^{\text {a }}$ Turma do TRT/RJ, da qual se pode verificar a íntegra:

\section{CERTIDÃO DE JULGAMENTO}

Certifico que, em sessão realizada nesta data, sob a Presidência do Desembargador Federal do Trabalho Marcos Cavalcante, com a presença do Ministério Público do Trabalho, na pessoa da Ilustre Procuradora Dra. Teresa Cristina D'Almeida Basteiro, e dos Excelentíssimos Desembargadores Federais do Trabalho Leonardo Pacheco e Angelo Galvão Zamorano, Relator, resolveu a $6^{\text {a }}$ Turma, retirar o feito de pauta ante o pedido de vista regimental do Desembargador Marcos Cavalcante. O Desembargador Relator CONHECIA do recurso interposto pela Reclamante e, no mérito, NEGAVALHE PROVIMENTO e, se vencido, juntará justificativa de voto. Fizeram uso da palavra a Dra. Emilianna Alves e o Dr. Paulo Máximo.

\section{CERTIFICO E DOU FÉ.}

Rio de Janeiro, 31 de julho de 2018.

CERTIDÃO PJe

Certifico que, nesta data, ante a solicitação recebida em 11/10/2018, via e-mail, em cumprimento à determinação do Exmo. Sr. Presidente da Egrégia $6^{\text {a }}$ Turma, foi realizada a remessa do DVD acautelado nesta unidade para a Secretaria da $6^{\mathrm{a}}$ Turma deste Regional, via mensageria.

RIO DE JANEIRO, 15 de Outubro de 2018

MARCO ANTONIO GUERRA DA SILVA

\section{CERTIDÃO DE REMESSA -PJe-JT}

Certifico que, nesta data, recebi o DVD que havia sido remetido ao Gabinete do Excelentíssimo Desembargador MARCOS CAVALCANTE, Rio de Janeiro, 18 de janeiro de 2019.

Observamos, assim, falha procedimental por remessa do processo ao segundo grau de jurisdição sem o DVD acautelado na secretaria da vara que veio a ser solicitado pelo relator, 
demonstrando desprestígio ao princípio da celeridade processual. Após o recebimento da mídia o recurso ordinário interposto pela autora foi apreciado pela turma a qual procedeu à lavra do acórdão cuja parte da fundamentação, ora transcrevemos, em sua literalidade:

Alega a reclamante que o inesperado fato ocorrido não pode ser atribuído a mesma, visto que para tal imputação seria necessário que ela fosse responsável apenas pelo mencionado paciente; sustenta que mesmo que o paciente acidentado estivesse exclusivamente sob os seus cuidados, força é convir que seria quase impossível que, em tais circunstâncias, a reclamante fosse capaz de impedir a queda de rapaz de físico atlético, com 22 anos, como consta no mencionado relatório; afirma que não há documento nos autos que comprove a proibição de mexer em aparelho celular durante o período de trabalho, requerendo a reforma da sentença que manteve a justa causa aplicada.

Sem razão.

Como se sabe, a demissão por justa causa é a mais rigorosa sanção que pode sofrer o empregado, eis que o priva da sua própria subsistência e a da sua família, além do fato de macular sua reputação pessoal e profissional, prejudicando-o na busca de novos empregos. Em razão disso é dever do empregador observar, antes de demitir por justa causa, os princípios basilares dos direitos pessoais e sociais, em especial a manutenção e continuidade do emprego, conforme previstos na Constituição Federal.

No caso dos autos, as alegações contidas na defesa quanto aos atos faltosos praticados pela reclamante foram devidamente comprovadas nos autos. Verifica-se que assim declarou o próprio reclamante em seu depoimento pessoal (id ff40a88):

"que foi dispensada em razão de um relato de que um paciente teria se jogado da cama; que percebeu que o paciente caiu da cama quando ouviu o barulho; que no momento da queda não estava no local, mas estava próximo; que apenas escutou o barulho; que no local em que a depoente estava havia monitor, sendo que tinha que virar o corpo para ver o monitor; que a depoente estava nesse local mexendo no seu telefone e fazendo os cálculos do paciente..."

E assim declarou a testemunha Sra. Ana Paula Gama Alves da Silva (id ff40a88):

"...que não sabe informar se a autora estava próxima do leito onde o paciente caiu; que não sabe onde a autora se encontrava no momento da queda..."

Diante do teor dos depoimentos acima transcritos, bem como o relato contido na sentenca acerca da imagem colhida pela câmera de seguranca do setor (conteúdo do DVD) que mostra a reclamante mexendo em seu celular (assistindo vídeos) por vários minutos enquanto o paciente demonstrava agitação, sem qualquer atitude da demandante, exatamente pela sua falta de atenção, não resta dúvida que a queda do paciente do leito poderia ter sido evitada.

Ressalte-se que o juízo original da instrução, ao colher o depoimento das partes e das testemunhas, tem o contato direto com elas, estando mais apto a apreciar o grau de segurança que cada um dos depoentes lhe passa. Assim, não ressaltando dos autos qualquer elemento que induza à convicção de que o Juízo de origem se equivocou na valoração da prova oral produzida, deve prevalecer o convencimento por ele firmado, com base nas vivas impressões colhidas por ocasião da produção probatória. 
Não restam dúvidas de que o comportamento inadequado da reclamante, que não interviu para evitar a queda do paciente no CTI, constituiu falta gravíssima, ensejando a dispensa por justa causa, prevista no artigo 482, "e", da CLT.

Ante o exposto, mantém-se a sentença que confirmou a justa causa aplicada a reclamante e julgou improcedentes os pedidos, por seus próprios e jurídicos fundamentos (negritos e sublinhados acrescidos).

Da detida análise da fundamentação do acórdão podemos observar que o relator usou como argumento principal os depoimentos colhidos fazendo apenas referência ao relato do juízo de primeiro grau sobre a prova em vídeo. Essa conduta levanta dúvida se o conteúdo das imagens foi efetivamente assistido pelo relator e pela turma aproximando-se o tratamento dado aos elementos imagéticos dos mitos "a imagem diz por si" (SHERWIN, 2011), abrindo uma “janela da realidade" sob uma ótica objetiva e imparcial (KAHAN, 2008), pelo excesso de confiança e supervalorização na apreciação de outro - no caso o primeiro grau de jurisdição sobre a prova imagética (PORTER, 2013). Lado outro, observamos prestígio desproporcional à palavra escrita sobre a prova em vídeo, o que nos remonta ao apego ao uso da palavra escrita e de elementos racionais, além de resistência na absorção da prova em vídeo decorrente das características contrapostas da Mídia e do Direito (RICCIO, et. al 2016).

Percebemos, também, que a fundamentação da sentença de primeiro grau iniciou-se com descrição minuciosa sobre as imagens assistidas para depois fazer comparação com os demais elementos de prova, o que ocorreu em sentido diverso no segundo grau. O acórdão inicia sua fundamentação dando ênfase aos depoimentos colhidos para depois, em simples relato sobre as imagens assistidas, pelo primeiro grau, fazer menção sobre os elementos imagéticos, o que reflete desequilíbrio entre a revolução tecnológica e a receptividade da prova imagética (SHERWIN, 2011) e fragilidade na interpretação cruzada do filme (SILBEY, 2004). Além disso, resta demonstrada a necessidade de atualização de conceitos legais como a argumentação jurídica e cultura jurídica (RICCIO, et al. 2016), pois as imagens foram pouco utilizadas pelo segundo grau de jurisdição, o qual confiou em excesso no relato do primeiro grau e deu prevalência aos elementos e argumentos técnicos típicos apenas dos operadores do direito, ou seja, utilizou em demasia da argumentação jurídica clássica, desconsiderando os argumentos multimodais que poderiam ter sido observados e ressaltados, em nítido apego à palavra escrita.

Outro detalhe a ser ressaltado é que a prova em vídeo foi tratada pelo segundo grau no mesmo patamar das provas documentais, não havendo nenhum detalhe específico que pudesse deixar evidente tratamento diferenciado pelo tipo de prova inovador e multimodal, o que evidencia a necessidade de estabelecimento de regramento específico pelo vácuo legislativo em 
que se encontra o ordenamento jurídico sobre a matéria. Por fim, temos que a prova em vídeo foi de certa forma ignorada ou pouco utilizada pelo segundo grau (PORTER, 2013) em flagrante resistência de sua utilização (RICCIO, et. al, 2016), o que, aliado a todos os demais aspectos observados, deixa visível a necessidade de alfabetização visual (SHERWIN, 2019).

A seguir as tabelas de parâmetros qualitativos:

TABELA DE PARÂMETROS QUALITATIVOS N. 1 - PROBLEMAS OBSERVADOS NA REVISÃO DA LITERATURA:

\begin{tabular}{|c|c|c|}
\hline & SENTENÇA & ACÓRDÃO \\
\hline $\begin{array}{l}\text { a) desequilíbrio da tecnologia e } \\
\text { o Direito. }\end{array}$ & $X$ & $\begin{array}{l}\sqrt{ } \\
\text { Sim, pela fundamentação em } \\
\text { mera referência ao relato das } \\
\text { imagens pelo primeiro grau, o } \\
\text { que levanta dúvida sobre a } \\
\text { efetiva visualização da prova } \\
\text { em vídeo. }\end{array}$ \\
\hline $\begin{array}{l}\text { b) resistência na absorção da } \\
\text { prova em vídeo. }\end{array}$ & $X$ & $\begin{array}{l}\text { V } \\
\text { Sim, resistência na utilização } \\
\text { da prova em vídeo, uma vez } \\
\text { que há dúvida se as imagens } \\
\text { foram visualizadas e houve } \\
\text { prevalência e apego ao uso da } \\
\text { palavra escrita. }\end{array}$ \\
\hline $\begin{array}{l}\text { c) desorganização } \\
\text { administrativa. }\end{array}$ & $\begin{array}{l}\sqrt{ } \\
\text { Sim, desorganização } \\
\text { administrativa } \\
\text { procedimento de remessa } \\
\text { do processo sem envio do } \\
\text { DVD acautelado em } \\
\text { secretaria, o que infringiu o } \\
\text { princípio da celeridade. }\end{array}$ & $X$ \\
\hline
\end{tabular}




\begin{tabular}{|c|c|c|}
\hline d) a imagem diz por si. & $\mathrm{X}$ & $\begin{array}{l}\sqrt{ } \\
\text { Sim, pela fundamentação } \\
\text { através de mera referência ao } \\
\text { relato das imagens assistidas } \\
\text { pelo primeiro grau de } \\
\text { jurisdição. }\end{array}$ \\
\hline $\begin{array}{l}\text { e) janela pra realidade, } \\
\text { imparcialidade do vídeo, } \\
\text { testemunha ocular, testemunha } \\
\text { silenciosa. }\end{array}$ & $\mathrm{X}$ & $\begin{array}{l}\sqrt{ } \\
\text { Sim, pelo excesso de } \\
\text { confiança na prova imagética } \\
\text { ao fazer mero relato das } \\
\text { imagens assistidas pelo } \\
\text { primeiro grau de jurisdição. }\end{array}$ \\
\hline $\begin{array}{l}\text { f) frágil interpretação cruzada } \\
\text { do filme. }\end{array}$ & $\mathrm{X}$ & $\mathrm{X}$ \\
\hline $\begin{array}{l}\text { g) iliberalismo cognitivo e } \\
\text { influência da emoção. }\end{array}$ & $\mathrm{X}$ & $\mathrm{X}$ \\
\hline $\begin{array}{l}\text { h) necessidade de atualização } \\
\text { de conceitos legais. }\end{array}$ & $X$ & $\begin{array}{l}\sqrt{ } \\
\text { Sim, a prova em vídeo foi } \\
\text { pouco utilizada pelo segundo } \\
\text { grau, havendo dúvida acerca } \\
\text { da visualização das imagens. }\end{array}$ \\
\hline Soluções propostas. & $\begin{array}{l}\text { Maior cautela e prudência } \\
\text { na fundamentação do } \\
\text { acórdão, sendo mais } \\
\text { expresso sobre } \\
\text { visualização das imagens. }\end{array}$ & \\
\hline
\end{tabular}

TABELA DE PARÂMETROS QUALITATIVOS N. 2: PONTOS RELEVANTES ABORDADOS.

PARÂMETROS: 


\begin{tabular}{|c|c|}
\hline $\begin{array}{l}1 \text { - o juiz de primeiro grau ou o desembargador, } \\
\text { de fato, assistiram à prova produzida em vídeo } \\
\text { e em que momento processual, em mesa de } \\
\text { audiências ou fora dela? }\end{array}$ & $\begin{array}{l}\text { As imagens foram assistidas pelo juiz de } \\
\text { primeiro grau, fora da mesa de } \\
\text { audiências, sem a presença das partes, } \\
\text { havendo dúvida se as imagens foram } \\
\text { visualizadas em sede de segundo grau. }\end{array}$ \\
\hline $\begin{array}{l}\text { 2- as imagens foram relevantes para a solução } \\
\text { da controvérsia jurídica tendo sido } \\
\text { mencionadas na fundamentação das decisões? }\end{array}$ & $\begin{array}{l}\text { As imagens foram utilizadas como } \\
\text { fundamento principal da sentença de } \\
\text { primeiro grau, com expressas referências } \\
\text { ao que visualizado e em comparação aos } \\
\text { demais elementos de prova. As imagens } \\
\text { foram utilizadas como fundamento } \\
\text { menos relevante do que os depoimentos } \\
\text { e documentos em sede de segundo grau, } \\
\text { havendo apenas referência ao relato das } \\
\text { imagens assistidas pela magistrada de } \\
\text { primeiro grau. }\end{array}$ \\
\hline $\begin{array}{l}3 \text { - qual o embasamento jurídico utilizado pelo } \\
\text { magistrado, subsunção a texto expresso de lei } \\
\text { ou prevalência de princípios (mandamentos de } \\
\text { otimização prima facie); houve respeito aos } \\
\text { princípios do devido processo legal, } \\
\text { contraditório e vedação à decisão surpresa } \\
\text { (interdisciplinaridade com o Processo Civil)? }\end{array}$ & $\begin{array}{l}\text { Não houve aplicação de texto de lei, } \\
\text { tampouco de princípios. Houve respeito } \\
\text { ao devido processo legal e vedação à } \\
\text { decisão surpresa no que se refere à } \\
\text { entrega da mídia à parte contrária e } \\
\text { oportunidade de impugnação. }\end{array}$ \\
\hline $\begin{array}{l}4 \text { - o conteúdo das imagens foi expressamente } \\
\text { impugnado por alguma parte, de modo a se } \\
\text { tornar necessária a produção de prova pericial } \\
\text { do vídeo apresentado? }\end{array}$ & $\begin{array}{l}\text { O conteúdo das imagens foi } \\
\text { expressamente impugnado pelo autor } \\
\text { que alegou, inclusive, adulteração, não } \\
\text { tendo sido determinado pelos } \\
\text { magistrados e desembargadores a } \\
\text { realização de prova pericial. }\end{array}$ \\
\hline $\begin{array}{l}5 \text { - se as demais provas dos autos foram } \\
\text { levadas em confronto às imagens analisadas? }\end{array}$ & $\begin{array}{l}\text { Sim, os demais elementos de prova } \\
\text { foram levados em confronto às imagens, } \\
\text { nos dois graus de jurisdição. }\end{array}$ \\
\hline
\end{tabular}




\begin{tabular}{|l|l|l|}
\hline $\begin{array}{l}6 \text { - restou evidenciada a necessidade de } \\
\text { alfabetização visual? }\end{array}$ & $\begin{array}{l}\text { A necessidade de alfabetização visual } \\
\text { restou verificada em sede de segundo } \\
\text { grau, pela resistência do intérpretes de se } \\
\text { valer das imagens trazidas aos autos. }\end{array}$ \\
\hline
\end{tabular}

\section{3 - Fundamentação diversa revertida pelo $2^{\circ}$ grau de jurisdição.}

\section{Processo 3}

Espécie e número do processo: rito ordinário trabalhista n. 010186942.2017.5.01.0071.

Data de ajuizamento: 04/6/2019.

Autor: pessoa física, cargo de garçom.

Ré: pessoa jurídica sob a forma empresarial Ltda, especializada no ramo de restaurantes.

Juízo de primeira instância: $71^{\text {a }}$ Vara do Trabalho do Rio de Janeiro.

Data de prolação da sentença: 07/01/2019.

Resultado: procedência em parte.

Juízo de segunda instância: $7^{a}$ Turma.

Data de prolação do acórdão: 13/08/2019.

Meio de ingresso da prova em vídeo: direto (acautelamento de mídia na secretaria da Vara).

Meio de análise da prova em vídeo: inicialmente o vídeo precisou ser assistido do celular de um dos advogados da parte ré, posteriormente foi assistido pela mídia trazida fora da mesa de audiências.

Perícia sobre o vídeo: não

Provimento do recurso: recurso parcialmente provido.

Relatório:

O processo n. 0101869-42.2017.5.01.0071, ajuizado em 09/11/2017 e transitado em julgado em 30/10/2019, trata de caso em que o trabalhador postulava a nulidade da justa causa aplicada pela empresa Ré, alegando não ter realizado atos que justificassem tal modalidade de ruptura contratual.

Em suma, o autor alegou ter esbarrado em outro garçom no restaurante, durante o trabalho de atendimento aos clientes, vindo sua bandeja a cair no chão, em razão da qual foi 
empurrado por este, o que o levou a apenas levantar o braço na frente para proteção, não tendo "brigado" em serviço.

A empresa Ré sustentou, na peça da defesa, a ocorrência de briga entre o autor e outro colega de trabalho, e que, diante disso, restou correta a dispensa por justa causa pela prática de agressão física no local e em horário de trabalho, conforme previsto no art. 482, alínea "j" da CLT, o que seria comprovado por gravação de imagens da câmera de circuito interno, postulando a exibição do vídeo em audiência de instrução.

Assim sustentou a ré na contestação, primeiro momento de menção à prova em vídeo no processo:

(...) diante dos fatos ocorridos dentro do estabelecimento da reclamante, em pleno horário de funcionamento e atendimento aos clientes. Neste ponto, requer a reclamada seja deferida a possibilidade de exibição de vídeo do circuito interno de câmera que registrou o incidente que motivou a aplicação da justa causa ao autor e ao outro colega de trabalho envolvido. Impugna a alegação do autor negando a ocorrência de briga entre o autor e outro atendente da reclamada. Tais fatos serão comprovados pela exibição do vídeo quando da realização da instrução processual ou em outra oportunidade ou forma que melhor entender este d. juízo. (Negritos acrescidos)"

Em audiência de instrução, a D. Magistrada realizou tentativa de assistir ao vídeo nos computadores do judiciário, o que não foi possível, pela incompatibilidade de formatos digital, tendo sido as imagens vistas do celular de um dos advogados das partes, como se fez constar, em ata de audiência:

"O vídeo, em formato MP4, anexado por pela ré e acautelado na Secretaria, pen drive não foi lido pelos computadores da sala de audiência, motivo pelo qual foi devolvido à ré.

O patrono da ré exibiu o citado vídeo em seu celular para esta Juíza e para o patrono do autor, que já tinha conhecimento de seu conteúdo.

Defere-se a ré o prazo de 15 dias para juntada do referido documento, com cópia para o autor, que ficará acautelado na secretaria. (Negritos acrescidos)"

Após a determinação de juntada de mídia que fosse possível a visualização na Vara do Trabalho, o advogado da ré procedeu à entrega de dois pen drives, na secretaria da Vara do Trabalho, sendo uma para a outra parte e outra para o Juízo, restando respeitados os princípios do contraditório, ampla defesa, vedação a decisão surpresa e o devido processo legal, conforme certidão em transcrição: 
Certifico que, nesta data, compareceu à esta Secretaria o advogado da reclamada, Gustavo Henrique Dias Martins (OAB/RJ 111335), trazendo dois pen drives para acautelamento (um para o juízo e outro para o autor), conforme determinado em ata. (Negritos e sublinhados acrescidos). RIO DE JANEIRO, 2 de Outubro de 2018

BIANCA ANDRADE BASTOS LUIZ

Nesse ponto destacamos que houve desequilíbrio entre a evolução da tecnologia e o ramo jurídico, por falta de tecnologia dos computadores institucionais para ler o conteúdo da mídia apresentada (SHERWIN, 2011). Todavia, tal fato não foi empecilho para a intérprete que, em conduta louvável e em harmonia aos princípios da celeridade, economicidade, busca e primazia da verdade, procedeu ao ato de assistir ao vídeo trazido em um celular de um dos advogados, com expressa ciência da parte contrária. Isso demonstra uma situação inusitada da incidência da tecnologia e do imagético no campo processual, revelando o descompasso de atualização técnica, contudo evidencia o esforço da julgadora para analisar as imagens e absorvê-las ao processo, afastando os problemas de resistência (RICCIO, et. al, 2016) e ignorância da prova em vídeo (PORTER, 2013).

Em razões finais, a ré impugnou as alegações do autor, trazendo prints das gravações (prova substantiva e demonstrativa, SILBEY, 2004), insistindo que a sequência de imagens não deixava dúvidas sobre a briga ocorrida, o que justiçava o enquadramento legal da conduta do autor na justa causa obreira, por agressão física em trabalho, conforme podemos observar abaixo.

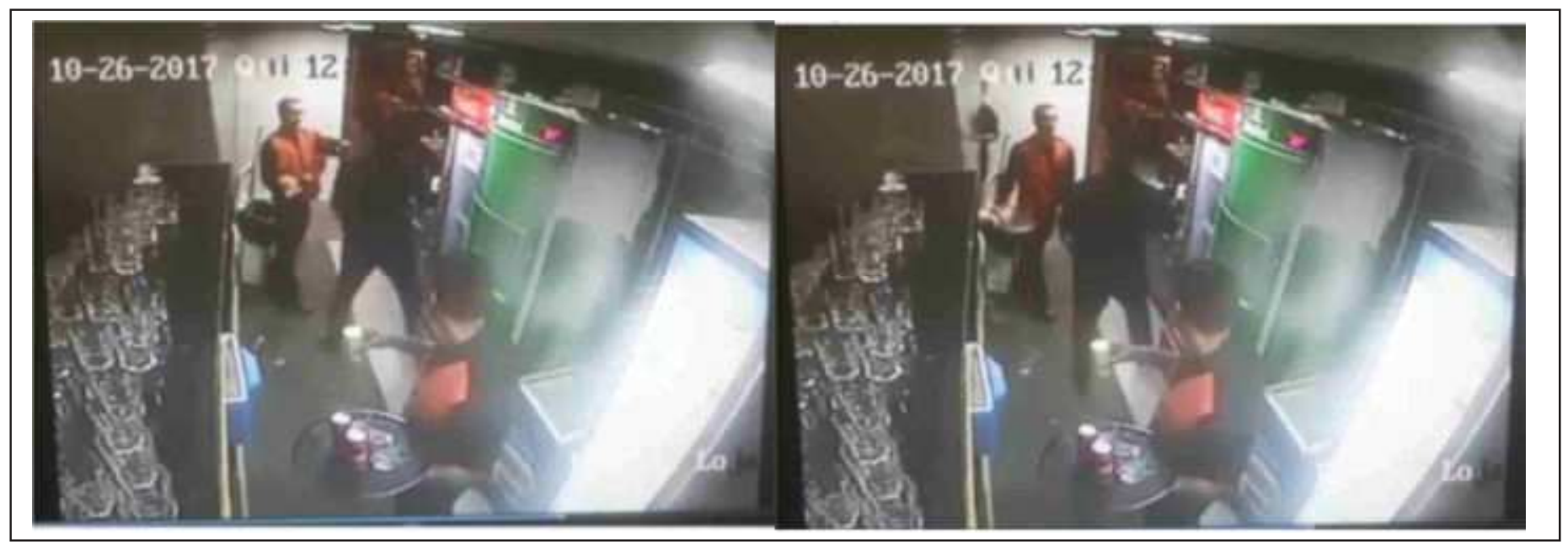




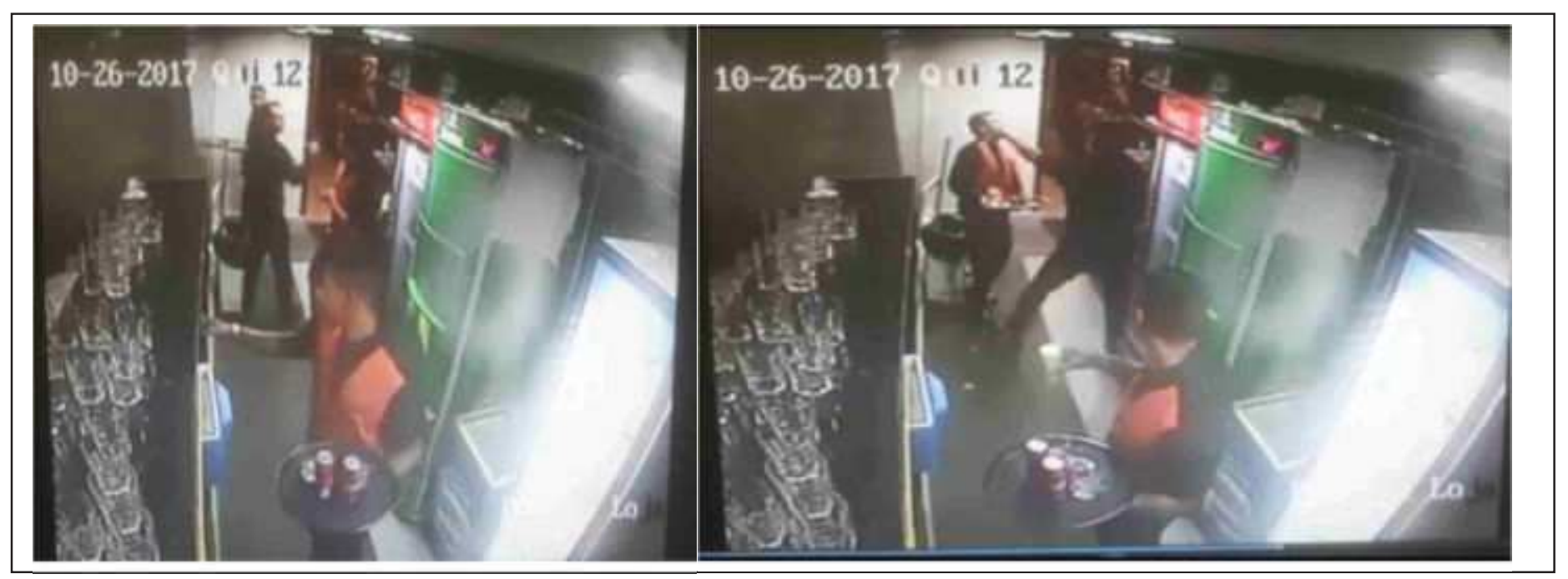

Apresentadas as razões finais, a julgadora proferiu à lavra da sentença da qual transcrevemos, na íntegra, a fundamentação do tópico de motivo de ruptura do contrato de trabalho:

Do Contrato de Trabalho

$\mathrm{O}$ autor afirmou que foi admitido em $1^{\circ}$ de outubro de 2016, para exercer a função de atendente, e dispensado em 27 de outubro de 2017, quando percebia a remuneração mensal no valor de $\mathrm{R} \$ 1.150,80$.

Narrou que esbarrou no seu colega João Paulo e que a bandeja que este carregava caiu no chão, no dia 26 de outubro de 2017. Ambos levantaram os braços e recolheram a bandeja com refrigerante e suco de laranja que haviam caído no chão. Após o incidente, o gerente Francisco mandou que trocassem de roupa e fossem para casa, dispensando-os por justa causa no dia seguinte, após tomarem o café da manhã.

A ré aduziu que o autor foi dispensado por justa causa, com fundamento no artigo 482, "j", da CLT.

\section{O vídeo exibido em Juízo demonstra que o autor e seu colega trocaram} agressões físicas após se esbarrarem na cozinha da ré.

A testemunha Sr. Antônio Felipe de Souza disse "que trabalha para a ré desde março de 2017; que exerce a função de atendente; que trabalhava com o autor; que presenciou a briga do reclamante com o senhor João; que não presenciou nenhum fato antes da briga; que já teve duas discussões com o autor por motivo de trabalho, consideradas normais pelo depoente; que o depoente fez uma brincadeira para o autor, o autor fez outra brincadeira para o depoente sobre família, que o depoente não gostou e cortou; que indagado sobre qual a brincadeira, o depoente disse apenas que era uma brincadeira de mau gosto; que já fez o autor fazendo brincadeira de mau gosto com outros colegas; que trabalhavam de $07 \mathrm{~h}$ a $16 \mathrm{~h} 45 \mathrm{~min}$, de segunda a sexta, com intervalo para refeição de uma hora (10h as $11 \mathrm{~h})$; que as equipes se dividiam e alternavam as saídas semanalmente; que em uma semana a equipe saía entre $14 \mathrm{~h} 30 \mathrm{~min} / 15 \mathrm{~h}$ e na semana subsequente saía as $16 \mathrm{~h} 10 \mathrm{~min} / 16 \mathrm{~h} 15 \mathrm{~min}$; que não podiam sair da empresa no intervalo para refeição; que durante o intervalo 
para refeição arrumavam as coisas e o tapete; que também poderiam ficar sentados descansando; que arrumava as coisas durante o intervalo para refeição porque era o serviço que tinha que fazer; que ouviu boatos de que o autor e o Sr Josimar havia brigado no banheiro; que ouviu boatos de que o autor também havia brigado com outros colegas de trabalho; que o autor e o Sr Josimar não se falavam; que não ouviu reclamação sobre o autor; que o restaurante abria as $11 \mathrm{~h}$; que o autor trabalhava no mesmo horário que o depoente; que o depoente assina controle de ponto com horário correto; que não havia folha de ponto quando o autor trabalhava para a ré; que não se lembra desde quando há controle de ponto na ré".

A testemunha Sr. Leonardo da Costa Silva disse "que trabalhou para a ré durante um ano e meio até janeiro de 2017, retornando em 01/11/2017, na função de atendente; que perguntado sobre o intervalo para refeição, respondeu que faz as tarefas até aproximadamente $9 \mathrm{~h} 20 / 9 \mathrm{~h} 30$, sobe para trocar de roupa e desce para almoçar as 10h00; que almoçam, rápido se quiserem um pouco mais de tempo; que uns saem e outros ficam; que precisam estar prontos às $11 \mathrm{~h} 00$, quando a casa abre; que trabalhou com o reclamante, aproximadamente, por três meses; que o restaurante abre ao público as $11 \mathrm{~h}$ e o intervalo para refeição era de $10 \mathrm{~h}$ a $11 \mathrm{~h}$ ".

Nos autos do processo distribuído sob o número 0102071-73.2017.5.01.0053, movido pelo Sr. João Paulo Santiago Vieira em face da ré, foram colhidos depoimentos na ata anexada com ID 653295f, que abaixo se transcrevem:

Em depoimento pessoal, o Sr. João Paulo Santiago Vieira disse "que esbarrou no seu colega Valmir, se empurraram, e foram interrompidos pelo gerente Francisco que pediu para o Depoente pegar suas coisas e ir para casa, o mesmo gerente pediu para o Sr. Valmir ficar no restaurante; que chegava no restaurante por volta de 06:30 horas, tomava o café da manhã fornecido pela Reclamada (10 a 15 minutos), começava efetivamente a trabalhar as 07:00 horas; que o intervalo para almoço levava no máximo 10 minutos, porquanto o Depoente começava a comer as 10:00, depois subia, se trocava e começava a arrumar as coisas para o público que chegaria às 11:00 horas; que não havia outro intervalo no meio da jornada que não esses 10 minutos; que era possível comer no buffet ao final da jornada, mas o Depoente raramente o fazia; esclareceu que no vídeo trazido pela empresa o Depoente é o que aparece nos fundos e que efetivamente sobe para os vestiários e vai para casa e que o Sr. Valmir é o magrinho e branquinho que fica no corredor depois do incidente". A testemunha Sr. Francisco Antônio Gomes Pedroza, disse "que trabalhou na ré de 2014 a fevereiro de 2018; que após chamar o reclamante de amigo, e pressionado pelo Magistrado, esclareceu que a amizade nasceu no trabalho mas que não se falaram depois da saída do Autor do restaurante, tendo apenas recebido o convite para participar dessa audiência; que almoçavam tanto na parte da manha quanto no final da jornada; que paravam para comer as 10:00/10:30 e levavam cerca de 30 minutos no almoço; que levavam outros 30 minutos para comer no buffet no final da jornada; que o reclamante também comia no buffet no final do dia; que o Autor levava "uns 20 minutos talvez" no almoço da parte da manhã".

A testemunha Sr. Francisco Antônio Mesquita Duarte disse "que acerca do incidente, esclareceu o Depoente que estava de frente para o corredor quando presenciou o Sr. Valmir esbarrar no Autor e na sequência este ter dado dois socos na cara do Sr Valmir; que ato seguinte, o Depoente ficou no meio dos dois e separou a briga; que nesse ponto o Autor arregaçou as mangas, fechou os punhos e o Depoente levantou os braços dizendo que não estava ali para apanhar; que então foi dito ao Autor que subisse, pegasse suas coisas e fosse para casa, pois não estava em condições de trabalhar; que o Depoente entrou no restaurante há 4 anos; que primeiro o Depoente respondeu que todos no 
restaurante tem apenas um horário de almoço (entre 10:00 e 11:00 horas) e depois de pressionado pelo Magistrado, esclareceu na verdade que no final da tarde os funcionários também podem almoçar; que pressionado pelo Magistrado pela segunda vez do crime de falso testemunho, retificou a testemunha o seu depoimento para esclarecer que o almoço se dava das 10:00 as 10:45, pois o restaurante devia ficar em ordem 15 minutos antes da abertura para o público que se dava as 11:00 horas; que se eventualmente o Autor terminasse o almoço as 10:30, poderia subir para o vestiário ou ir para a rua".

Tendo este Juízo visto no vídeo exibido pela ré as agressões físicas praticadas pelo autor no corredor da cozinha do estabelecimento da ré contra seu colega de trabalho, conclui que cometeu a falta prevista no artigo 482, " $j "$, da CLT.

Indeferem-se os pedidos de declaração de nulidade da dispensa por justa causa, retificação da anotação de baixa na CTPS do autor, entrega de guias para saque de FGTS e recebimento de seguro desemprego, pagamento de aviso prévio, férias proporcionais com $1 / 3$, décimo terceiro proporcional, indenização de $40 \%$ sobre o FGTS.

Deferem-se os pedidos de pagamento de salário de outubro de 2017 (27 dias), férias de 2016/2017, com 1/3.

Não tendo a ré comprovado o pagamento das parcelas rescisórias incontroversas, defere-se o pedido de pagamento da multa do artigo 477, da CLT, no valor de um salário base, bem como a multa prevista no artigo 467, da CLT, equivalente a 50\% sobre o salário de outubro de 2017 (27 dias) e férias de 2016/2017, com 1/3. (Negritos e sublinhados acrescidos)"

Como se vê, a decisão considerou que o autor praticou atos de agressão física no trabalho, tendo declarado o encerramento do liame de emprego por justa causa do trabalhador, conforme artigo 482, j da CLT. Nesse contexto, há de ressaltarmos aspectos importantes acerca da consideração da prova em vídeo no processo em relevo. A prova em vídeo teve sua origem de câmera de segurança do local de trabalho, onde não houve gravação do áudio, mas somente de imagens. A parte contrária teve oportunidade de se manifestar, em prazo razoável, expressamente acerca do conteúdo das imagens apresentando apenas argumentos jurídicos e fáticos a seu favor não impugnando o conteúdo, a veracidade ou eventual manipulação indevida, motivo pelo qual não se revelou necessária a produção de prova pericial.

O vídeo não foi remetido ao segundo grau de jurisdição de forma concomitante a sua remessa virtual, tendo sido necessária sua solicitação ao juízo de origem, o que nos mostra a ocorrência de desorganização administrativa em detrimento à celeridade processual. A prova produzida em vídeo exerceu influência direta e de enorme relevo no convencimento da intérprete, em primeiro grau de jurisdição, podendo-se observar que a fundamentação da decisão utilizou a mídia como principal embasamento, ou seja, a prova mediática foi decisiva para o deslinde da questão em exame. Contudo, podemos observar que a decisão de primeiro grau, após transcrever na sentença partes dos depoimentos colhidos, terminou pautando sua decisão apenas no vídeo assistido. 
Nesse ponto nos parece evidente a influência do aspecto emocional e do poder persuasivo da imagem os quais levaram a julgadora a proceder à decisão precipitada, demonstrando uma análise superficial das imagens, sem se ater aos detalhes específicos os quais foram, inclusive, ressaltados pela principal testemunha que participou do ocorrido separando os garçons no momento do ocorrido, tendo havido fraca interpretação cruzada do filme, ou seja, no interrogatório e interlocução do vídeo para com os demais elementos de prova (SILBEY, 2004). A decisão transcreve todos os depoimentos colhidos sem tecer comentários sobre estes e justifica a conclusão com base apenas na prova em vídeo para destacar que o autor e seu colega de trabalho haviam trocado agressões físicas no âmbito de trabalho o que justificava a aplicação da justa causa. A nosso sentir, nesse ponto houve aproximação da fundamentação aos mitos de "a imagem diz por si" (SHERWIN, 2011), e de "janela para a realidade" (SILBEY, 2004), como se a intérprete estivesse assistindo ao acontecido com seus próprios olhos, evidenciando, assim, uma supervalorização da prova mediática (PORTER, 2013) e um julgamento superficial imbuída de excesso de autoconfiança na objetividade das imagens assistidas (SILBEY, 2004).

Ademais, a conclusão, precipitada e superficial, sobre os fatos assistidos, deixa latente a dúvida se houve a incidência subconsciente de fatores psicológicos, sociais e culturais da vivência do intérprete que deixou "a imagem falar por si" sem considerar que a testemunha ouvida afirmou que, na realidade, o autor havia sido vítima da agressão e não o agressor. Parecenos que a decisão sofreu influência subconsciente da experiência de vida e profissional da prolatora da decisão a qual, por já ter presenciado, em diversos momentos da vida profissional, agressões físicas no trabalho, não analisou as imagens de forma mais apurada e específica, deixando de extrair dali o máximo da realidade do ocorrido, concluindo, de plano, que houve briga no âmbito de trabalho, sem averiguar se, de fato, o autor havia praticado algum ato de agressão. Nesse aspecto, a decisão se aproxima do iliberalismo cognitivo (FEIGENSON, 2014) e do realismo ingênuo (SHERWIN, 2019), por acreditar ingenuamente no que se assistia.

A parte autora recorreu de forma ordinária, tendo sido o feito distribuído para a $7^{\mathrm{a}}$ Turma do E. TRT/RJ, o qual teve que solicitar o envio da mídia acautelada na $1^{\text {a }}$ instância, conforme se extrai da certidão, ora transcrita, o que demonstra falha procedimental em desprestígio à celeridade processual, além de desequilíbrio entre a tecnologia e o campo processual (SHERWIN, 2011):

Processo: 0101869-42.2017.5.01.0071 - RO

Certifico o recebimento da mídia (pendrive), solicitada ao MM. Juízo da $\underline{\mathbf{7 1}^{\mathbf{a}}}$ Vara do Rio de Janeiro, razão pela qual procedo ao acautelamento da referida mídia. Faço conclusos os autos ao Exmo. Sr. Relator. 
Em 18 de Junho de 2019

Márcia Macedo da Graça

Técnico Judiciário

Em razão do recurso interposto, a $7^{\mathrm{a}}$ Turma do TRT/RJ lavrou o seguinte acórdão, transcrição da fundamentação do tópico justa causa:

\section{NO MÉRITO \\ DA JUSTA CAUSA}

A sentença de $1^{\circ}$ grau reconheceu a existência de motivos que ensejaram a justa causa aplicada pela Ré, por ter concluído que o Autor agrediu seu colega de trabalho, Sr. João Paulo Santiago Vieira, ante a exibição de imagens obtidas da câmera de vídeo instalada na cozinha do estabelecimento da Ré, local onde ocorreu o fato. O Recorrente busca ver reformada a decisão original para que seja convertida a dispensa por justa causa a ele aplicada em dispensa imotivada, com o pagamento das verbas rescisórias correspondentes ao encerramento contratual sem justa causa, sustentando que o Autor foi agredido e não revidou à agressão por ele recebida; não restando comprovado, portanto, que o obreiro tenha contribuído para ser condenado à pena de dispensa por justa causa.

Passemos à análise. Foi produzida prova testemunhal nos presentes autos, bem como foi apreciada prova testemunhal produzida nos autos do processo 0102071-73.2017.5.01.0053, ajuizado contra a Ré pelo Sr. João Paulo, o mesmo envolvido com o Acionante no fato ocorrido mencionado pelas partes. Foram também analisadas as cenas do evento, sem áudio. Com relação à prova oral produzida nos presentes autos, constata-se que na ata de ID. $8 \mathrm{db} 286 \mathrm{e}$, o Sr. Francisco Antonio Gomes Pedroza, testemunha do Autor, não auxiliou na elucidação dos fatos, uma vez que não os presenciou. O Sr. Josemar Galdino dos Santos, testemunha trazida pela Acionada, por seu turno foi contraditada pelo Autor, sob a alegação de ser inimiga capital do obreiro; o que foi acolhido pela Magistrada de $1^{\circ}$ grau, que entendeu haver demonstração de ânimo de inimizade. Os demais depoimentos produzidos nestes autos (ata de ID. 16100ed) foram os de duas testemunhas da Ré.

A $1^{\text {a }}$ delas, Sr. Antônio Felipe de Souza, declinou:

"que trabalhava com o autor; que presenciou a briga do reclamante com o senhor João; que não presenciou nenhum fato antes da briga; que já teve duas discussões com o autor por motivo de trabalho, consideradas normais pelo depoente; que o depoente fez uma brincadeira para o autor, o autor fez outra brincadeira para o depoente sobre família, que o depoente não gostou e cortou; que indagado sobre qual a brincadeira, o depoente disse apenas que era uma brincadeira de mau gosto; que já fez o autor fazendo brincadeira de mau gosto com outros colegas; (...) que ouviu boatos de que o autor e o Sr Josimar havia brigado no banheiro; que ouviu boatos de que o autor também havia brigado com outros colegas de trabalho; que o autor e o Sr Josimar não se falavam; que não ouviu reclamação sobre o autor (...)".

O Sr. Leonardo da Costa Silva, $2^{a}$ testemunha da Acionada, não trouxe mais esclarecimentos, apenas afirmando que trabalhou como o Demandante por aproximadamente três meses. No que tange aos depoimentos pertencentes ao processo 0102071- 73.2017.5.01.0053, eles constam na r. sentença de ID. 6b268ba, prolatada nos presentes autos.

O depoimento do Sr. João Paulo Santiago Vieira, autor da referida ação trabalhista e, conforme já ressaltado, envolvido no incidente com o Sr. Valmir, Autor da presente ação, declinou: 
"que esbarrou no seu colega Valmir, se empurraram, e foram interrompidos pelo gerente Francisco que pediu para o Depoente pegar suas coisas e ir para casa, o mesmo gerente pediu para o Sr. Valmir ficar no restaurante; (...) esclareceu que no vídeo trazido pela empresa o Depoente é o que aparece nos fundos e que efetivamente sobe para os vestiários e vai para casa e que o Sr. Valmir é o magrinho e branquinho que fica no corredor depois do incidente." O Sr. Francisco Antônio Gomes Pedroza, que também depôs nos autos que tramitam junto à $53^{\mathrm{a}}$ Vara do Trabalho do Rio de Janeiro, também não trouxe maiores esclarecimentos.

Já a testemunha Francisco Antônio Mesquita Duarte declarou:

"que acerca do incidente, esclareceu o Depoente que estava de frente para o corredor quando presenciou o Sr. Valmir esbarrar no Autor e na sequência este ter dado dois socos na cara do Sr Valmir; que ato seguinte, o Depoente ficou no meio dos dois e separou a briga; que nesse ponto o Autor arregaçou as mangas, fechou os punhos e o Depoente levantou os braços dizendo que não estava ali para apanhar; que então foi dito ao autor que subisse, pegasse suas coisas e fosse para casa, pois não estava em condições de trabalhar (...)".

Foi possível examinar as imagens produzidas pela câmera constantes no pendrive solicitado por esta instância revisional e delas se extrai, em síntese, que o Sr. Valmir, autor na presente acão, foi quem recebeu a agressão, conforme afirmado pelo Sr. Francisco Duarte. Após ver as imagens, é perfeitamente possível perceber que o Demandante, segurando a bandeja, e o outro empregado, Sr. João Paulo, iniciam uma troca de gestos e falas (não registradas), que termina lamentavelmente com o Autor sendo agredido. Nestes termos, é absolutamente indevida a justa causa que lhe foi aplicada.

A dispensa por justa causa constitui a punição mais severa ao empregado, importando falta de extrema gravidade que conduz à perda do emprego sem qualquer indenização pelo tempo de serviço prestado ao empregador. Assim, para a validação da sua aplicação, deve o empregador produzir prova no curso da instrução processual que demonstre o cometimento de falta grave pelo trabalhador, à luz da regra de distribuição do ônus da prova (art. 818, da CLT). Neste sentido, competia à Acionada o encargo processual de comprovar, de forma inequívoca, a má conduta do obreiro, capaz de justificar a ruptura contratual por justa causa. O comportamento patronal revelou-se rigoroso e desproporcional, violando o princípio protetivo que informa o Direito do Trabalho e afrontando o princípio da razoabilidade. Entendo que a situação noticiada nos autos poderia conduzir à quebra de confiança necessária à manutenção do vínculo de emprego, mas não configurou, por si só, hipótese justificadora de dispensa por justa causa. E concluindo o empregador que o obreiro não mais gozava de sua confiança para que fosse mantido o contrato de trabalho, poderia simplesmente ter exercitado o seu direito potestativo de romper imotivadamente a relação de emprego, garantindo-lhe o pagamento das verbas derivadas da dispensa imotivada. A postura desproporcional por ele adotada, ao aplicar a penalidade máxima, dá azo à desqualificação da resolução contratual de forma motivada, em razão do excessivo rigor no exercício do poder diretivo, devendo ser considerado o encerramento contratual por dispensa imotivada, sendo devidas as verbas rescisórias sonegadas à época da extinção do contrato de trabalho, a saber: aviso prévio de 33 dias, férias proporcionais de $2017+1 / 3,13^{\circ}$ salário proporcional, liberação das guias de FGTS e pagamento da multa compensatória de 40\%, bem como a entrega das guias $\mathrm{CD}$, para habilitação à

percepção do seguro desemprego, uma vez que o pagamento do saldo de salário e das férias integrais de 2016/2017 + 1/3 já foi deferido pela r. sentença. 
Dou provimento.

Como se vê, o segundo grau de jurisdição interpretou as imagens de forma diversa, ressaltando que o autor não havia praticado ato de agressão física no local de trabalho, tendo, na realidade, sido vítima de agressão, afastando, assim, a justa causa que lhe havia sido aplicada, dando procedência ao recurso para reformar a sentença de primeiro grau. Para tal, o relator utilizou-se das imagens assistidas e da interpretação cruzada do filme (SILBEY, 2004) para com os demais elementos de prova, tais como os depoimentos colhidos pela prova oral. Assim, o relator, analisando as imagens de forma mais apurada, destacou que foi perfeitamente possível perceber que, tal como afirmado pela testemunha, o autor havia sido vítima de agressão descrevendo com detalhes o que visualizou na tela - inclusive ressaltando a ausência de sons na gravação - onde se observou que o demandante segurava a bandeja quando se iniciou troca de gestos e falas para com outro empregado, a qual terminou com o autor sendo agredido.

Assim, a nosso sentir, o relator afastou o liberalismo cognitivo (FEIGENSON, 2014) ao realizar a devida pausa mental e tomou a cautela necessária no ato de assistir às imagens (PORTER, 2013), procedendo a uma decisão mais aproximada da realidade, com a necessária humildade judicial (SHERWIN, 2011) de se reconhecer que os fatos controvertidos necessitavam de apreciação mais apurada, neutralizando, assim, possíveis incidências de vieses subconscientes do que habitualmente enfrentado na justiça trabalhista, uma vez que ações em que se discutem agressões físicas são constantes no ramo laboral. Afastou-se, assim, o excesso de autoconfiança e a análise precipitada, superficial e supervalorizada da imagem (PORTER, 2013), não se deixando que a imagem falasse por si (SHERWIN, 2011), procedendo-se a uma decisão mais justa e equilibrada, dentro das possibilidades ora vivenciadas pela justiça trabalhista diante da avassaladora avalanche digital experimentada, corrigindo os problemas identificados na decisão de primeiro grau.

A seguir as tabelas de parâmetros qualitativos:

TABELA DE PARÂMETROS QUALITATIVOS N. 1 - PROBLEMAS OBSERVADOS NA REVISÃO DE LITERATURA:

\begin{tabular}{|l|l|l|}
\hline & SENTENÇAS & ACÓRDÃOS \\
\hline a) desequilíbrio da tecnologia e & $\sqrt{ }$ & X \\
o Direito. & Sim, pela análise superficial da & \\
& prova em vídeo, deixando-se & \\
& influenciar pelo poder & \\
\hline
\end{tabular}




\begin{tabular}{|c|c|c|}
\hline & $\begin{array}{l}\text { emocional e persuasivo da } \\
\text { imagem, sem proceder à sua } \\
\text { análise de forma detida, } \\
\text { cautelosa e apurada. }\end{array}$ & \\
\hline $\begin{array}{l}\text { b) resistência na absorção da } \\
\text { prova em vídeo. }\end{array}$ & $\begin{array}{l}\sqrt{ } \\
\text { Sim, pela análise superficial da } \\
\text { imagem. }\end{array}$ & $\mathrm{X}$ \\
\hline $\begin{array}{l}\text { c) desorganização } \\
\text { administrativa. }\end{array}$ & $\begin{array}{l}\sqrt{ } \\
\text { Sim, falha no procedimento de } \\
\text { remessa do processo sem envio } \\
\text { da mídia acautelada em } \\
\text { secretaria, o que infringiu o } \\
\text { princípio da celeridade. } \\
\text { Ademais, as imagens } \\
\text { precisaram ser assistidas, em } \\
\text { sede de primeiro grau de } \\
\text { jurisdição, através de um } \\
\text { celular das partes, por } \\
\text { incompatibilidade física de } \\
\text { aparelhos eletrônicos. }\end{array}$ & $\mathrm{X}$ \\
\hline d) a imagem diz por si. & $\begin{array}{l}\sqrt{ } \\
\text { Sim, pelo excesso de confiança } \\
\text { na prova imagética, analise } \\
\text { superficial, imbuída de excesso } \\
\text { de autoconfiança, influenciada } \\
\text { pelo poder emocional e } \\
\text { persuasivo da imagem. }\end{array}$ & $\mathrm{X}$ \\
\hline $\begin{array}{l}\text { e) janela pra realidade, } \\
\text { imparcialidade do vídeo, } \\
\text { testemunha ocular, testemunha } \\
\text { silenciosa. }\end{array}$ & $\begin{array}{l}\sqrt{ } \\
\text { Sim, pelo excesso de confiança } \\
\text { na objetividade da prova } \\
\text { imagética, deixando passar a }\end{array}$ & $\mathrm{X}$ \\
\hline
\end{tabular}




\begin{tabular}{|c|c|c|}
\hline & $\begin{array}{l}\text { imagem de que se assistia aos } \\
\text { fatos com seus próprios olhos. }\end{array}$ & \\
\hline $\begin{array}{l}\text { f) frágil interpretação cruzada } \\
\text { do filme. }\end{array}$ & $\begin{array}{l}\sqrt{ } \\
\text { Sim, pela análise precipitada e } \\
\text { superficial da imagem sem } \\
\text { atentar-se para o que a } \\
\text { testemunha havido relatado } \\
\text { sobre os fatos. }\end{array}$ & $\mathrm{X}$ \\
\hline $\begin{array}{l}\text { g) iliberalismo cognitivo e } \\
\text { influência da emoção. }\end{array}$ & $\begin{array}{l}\sqrt{ } \\
\text { Sim, pela análise precipitada e } \\
\text { superficial da imagem deixando } \\
\text { transparecer a influência de } \\
\text { fatores sociais, culturais e } \\
\text { psicológicos subconscientes } \\
\text { sobre recorrente análise de } \\
\text { casos de agressões físicas em } \\
\text { âmbito laboral }\end{array}$ & $\mathrm{X}$ \\
\hline $\begin{array}{l}\text { h) necessidade de atualização } \\
\text { de conceitos legais. }\end{array}$ & $\begin{array}{l}\sqrt{ } \\
\text { Sim, a prova em vídeo foi } \\
\text { supervalorizada em uma } \\
\text { interpretação precipitada e } \\
\text { superficial, influenciada pela } \\
\text { emoção e o poder persuasivo } \\
\text { das imagens, sem confronto aos } \\
\text { demais elementos de prova. }\end{array}$ & $\mathrm{X}$ \\
\hline Soluções propostas. & $\begin{array}{l}\text { Maior cautela e prudência na } \\
\text { análise das imagens, em } \\
\text { primeiro grau, realizando uma } \\
\text { pausa mental no objetivo de se } \\
\text { averiguar se os fatos poderiam } \\
\text { ser interpretados de forma } \\
\text { diversa. }\end{array}$ & \\
\hline
\end{tabular}


TABELA DE PARÂMETROS QUALITATIVOS N. 2: PONTOS RELEVANTES ABORDADOS.

\begin{tabular}{|c|c|}
\hline PARÂMETROS: & \\
\hline $\begin{array}{l}1 \text { - o juiz de primeiro grau ou o } \\
\text { desembargador, de fato, assistiram à prova } \\
\text { produzida em vídeo e em que momento } \\
\text { processual, em mesa de audiências ou fora } \\
\text { dela? }\end{array}$ & $\begin{array}{l}\text { As imagens foram assistidas pelo juiz de } \\
\text { primeiro grau em mesa de audiências, com a } \\
\text { presença das partes, em aparelho de celular de } \\
\text { advogado da parte. }\end{array}$ \\
\hline $\begin{array}{l}2 \text { - as imagens foram relevantes para o } \\
\text { deslinde da controvérsias jurídica tendo sido } \\
\text { mencionadas na fundamentação das } \\
\text { decisões? }\end{array}$ & $\begin{array}{l}\text { As imagens foram utilizadas como fundamento } \\
\text { principal da sentença de primeiro grau, com } \\
\text { referência expressa ao que visualizado, porém } \\
\text { de forma precipitada, superficial } \\
\text { desconsiderando os demais elementos de prova. } \\
\text { As imagens foram utilizadas como fundamento } \\
\text { do acórdão de segundo grau, em comparação aos } \\
\text { demais elementos de prova, de forma mais } \\
\text { cautelosa e prudente. }\end{array}$ \\
\hline $\begin{array}{l}3 \text { - qual o embasamento jurídico utilizado } \\
\text { pelo magistrado, subsunção a texto expresso } \\
\text { de lei ou prevalência de princípios } \\
\text { (mandamentos de otimização prima facie); } \\
\text { houve respeito aos princípios do devido } \\
\text { processo legal, contraditório e vedação à } \\
\text { decisão surpresa (interdisciplinaridade com o } \\
\text { Processo Civil)? }\end{array}$ & $\begin{array}{l}\text { Não houve aplicação de texto de lei, tampouco } \\
\text { de princípios. Houve respeito ao devido } \\
\text { processo legal e vedação à decisão surpresa no } \\
\text { que se refere à entrega da mídia à parte contrária } \\
\text { e oportunidade de impugnação. }\end{array}$ \\
\hline $\begin{array}{l}4-\text { o conteúdo das imagens foi } \\
\text { expressamente impugnado por alguma parte, } \\
\text { de modo a se tornar necessária a produção de } \\
\text { prova pericial do vídeo apresentado? }\end{array}$ & $\begin{array}{l}\text { O conteúdo das imagens não foi expressamente } \\
\text { impugnado não tendo alegação de adulteração, o } \\
\text { que tornou desnecessária a realização de prova } \\
\text { pericial. }\end{array}$ \\
\hline $\begin{array}{l}5 \text { - se as demais provas dos autos foram } \\
\text { levadas em confronto às imagens analisadas? }\end{array}$ & $\begin{array}{l}\text { Os demais elementos de prova foram levados } \\
\text { em confronto às imagens, apenas no segundo } \\
\text { grau de jurisdição. }\end{array}$ \\
\hline
\end{tabular}




\begin{tabular}{|c|c|}
\hline $\begin{array}{l}6 \text { - restou evidenciada a necessidade de } \\
\text { alfabetização visual? }\end{array}$ & $\begin{array}{l}\text { A necessidade de alfabetização visual restou } \\
\text { verificada, principalmente pela incidência de } \\
\text { problemas clássicos identificados pela revisão } \\
\text { da literatura, em sede de primeiro grau, tais } \\
\text { como iliberalismo cognitivo, realismo ingênuo, } \\
\text { ausência de interpretação cruzada do filme, a } \\
\text { imagem diz por si, excesso de autoconfiança na } \\
\text { objetividade da imagem. }\end{array}$ \\
\hline
\end{tabular}




\section{6 - CONSIDERAÇÕES FINAIS:}

A pesquisa deixou clara a existência de desequilíbrio entre o avanço tecnológico e sua absorção ao ramo jurídico, acentuado pela complexidade da sociedade contemporânea, impregnada pela imagem e o tecnológico. As transformações sociais decorrentes da tecnologia e a extrema facilidade de produção de imagens, invadiram o campo jurídico processual trabalhista, fazendo com que o intérprete se depare, habitualmente, com modernos tipos de provas, como as em vídeo, o que tem gerado situações inimagináveis e inusitadas, desafiando a busca de novos conhecimentos. Nesse aspecto inusitado, os três casos estudados podem ser considerados emblemáticos por representarem situações fáticas complexas de confronto entre o tecnológico e o imagético versus o ambiente de trabalho e o mundo processual. Por exemplo, o primeiro caso refere-se a imagens gravadas de câmera instalada dentro de transporte coletivo municipal às quais, geradas para dar segurança aos cidadãos, acabaram tornando-se prova processual, incidindo diretamente em uma relação jurídico trabalhista onde se discutiam fatos ímprobos por parte do trabalhador.

A mídia, único meio de prova conseguido pela ré, não teve seu conteúdo analisado pelos intérpretes por considerarem obrigação da parte apresentar aparelho suficiente para exibição das imagens, o que, de certa forma, demonstra dificuldade dos operadores do Direito em lidar com algo novo e diferente do costume jurídico processual praticado há décadas. O segundo caso trata de gravações de câmera interna de um hospital, a qual flagrou uma profissional assistindo vídeos, em seu smartphone, em pleno expediente de trabalho, à beira de uma cama de CTI, em virtude da qual se descuidou do paciente que veio a cair no chão. As imagens foram assistidas pelo intérprete em sede de primeiro grau de jurisdição, não se tendo certeza se o segundo grau procedeu à sua visualização, pois a decisão apenas fez referência ao ato de assistir do primeiro grau, desprestigiando as provas em vídeo em detrimento das provas clássicas pautadas pelo uso racional da palavra escrita, o que o fez manter a decisão de piso.

Nítida a presença do tecnológico e imagético, onde o local de trabalho encontrava-se equipado de câmeras às quais gravaram a trabalhadora usando smartphone para assistir vídeos o que acabou incidindo em campo processual, sendo determinante para a resolução do impasse jurídico. Já o terceiro caso referiu-se a gravações de câmeras internas de um restaurante às quais foram assistidas em primeira instância, através de um smartphone de um dos advogados das partes, por incompatibilidade do formato digital dos vídeos com os aparelhos institucionais do judiciário. Tais situações jamais poderiam ser imaginadas há dez anos atrás, onde não era possível supor que as relações sociais seriam atingidas por transformações tão intensas e inovadoras em um nível imagético e tecnológico tão relevante. 
As reações dos intérpretes, em relação a tais situações contemporâneas, responderam às perguntas objeto do presente estudo, deixando à mostra que a imagem é um meio de prova extremamente relevante fazendo-se prevalecer nas decisões judiciais trabalhistas, às quais, todavia, também incidem nos mitos e problemas, identificados na revisão da literatura, como recorrentes, em decisões judiciais, na justiça norte-americana. Não por descaso ou de forma intencional, mas em virtude da natureza paradoxal dos objetos em estudo, a mídia e o Direito (RICCIO, et. al. 2018), e do contexto social de desequilíbrio entre a velocidade da aparição de novas provas tecnológicas e sua inserção ao meio jurídico (SHERWIN, 2011). Os três casos estudados revelaram dificuldade do ramo trabalhista em enfrentar as novidades, inseridas, abruptamente, em um meio com características historicamente opostas, revelando que o preparo para maior habilidade e eficiência dos operadores do Direito trabalhista para enfrentá-las seria algo bastante razoável (RICCIO, et al. 2004).

Assim, os casos demonstraram a ocorrência de desorganização administrativa, como, por exemplo, falta de aparelho e incompatibilidade de formatos digitais das gravações para exibição de imagens em ambiente institucional do judiciário e ausência de envio imediato das mídias ao segundo grau de jurisdição. Confirmamos a hipótese inicial de desconfiança e resistência na utilização das provas em vídeo, seja por apego aos arcaicos métodos argumentativos, exclusivamente racionais, atinentes à origem romano germânica do direito, seja pela insistência no uso exclusivo do tecnicismo formal do direito e da palavra escrita, em detrimento das novas técnicas argumentativas e formas de análise necessárias para a justa apreciação e inserção dos elementos simbólicos e emocionais das imagens na cultura jurídica (RICCIO, et al. 2012).

Em síntese, após análise qualitativa dos casos em concreto, confirmamos que, tal como na justiça norte-americana, aqui também há dissonância de decisões acerca da admissibilidade da prova em vídeo e relevante dificuldade de sua interpretação. Ora a prova em vídeo é ignorada, ora é supervalorizada (PORTER, 2013) por interpretação superficial e precipitada, seduzida pelo poder persuasivo emocional da imagem desaguando nos clássicos equívocos da “imagem diz por si" (SHERWIN, 2011) e "a imagem abre uma janela para a realidade tornando o espectador em "testemunha ocular dos fatos (SILBEY, 2004)", sendo desprovida de subjetividade e dubiedade (KAHAN, 2008), funcionando como uma "testemunha silenciosa (SILBEY, 2008)". Observamos, também, fragilidade e dubiedade na interpretação cruzada do filme para com os demais elementos de prova (SILBEY, 2004), além da incidência do realismo ingênuo e do iliberalismo cognitivo, em decisões influenciadas por fatores subconscientes, culturais, psicológicos e sociais (FEIGENSON, 2014). 
Tudo isso reflete a necessidade de harmonização e uniformização acerca do procedimento e do regramento a serem adotados, bem como do exercício de maior prudência e cautela na interpretação das imagens, no objetivo de se minimizar a prolação de uma decisão eivada pela incidência dos problemas acima relatados (SHERWIN, 2019). Logo, o estudo qualitativo respondeu afirmativamente em relação à indagação a qual deu origem a esta pesquisa, no sentido da necessidade de preparo e de se proceder à alfabetização visual dos operadores do direito do trabalho brasileiros, no objetivo de trazer maior habilidade e eficiência na análise de elementos probatórios inovadores. Isso em virtude da difusão generalizada de provas em meios digitais, ocasionada pela revolução tecnológica, o que as tornou elementos essenciais para a contextualização da seara jurídica trabalhista ao complexo global contemporâneo. Ficou visível para nós que a imagem realmente fragiliza o discurso racionalista tradicional do Direito, por sua faceta emocional e que o excesso de imagens no mundo moderno, impregnado pelo estilo barro de profusão descontrolada de imagens emocionalmente poderosas, tem trazido grande dificuldade de extração do real conteúdo do imagético, afastando-nos, assim, de uma decisão mais justa e equilibrada (SHERWIN, 2011).

Há de haver interpretação detida, equânime e justa, o que requer reconhecimento da necessidade de aprendizado de novos conhecimentos de várias disciplinas (SHERWIN, 2019). A modernização dos instrumentos e meios de prova torna praticamente obrigatório o preparo dos operadores do direito para sua correta e justa abordagem, no objetivo de pacificar os conflitos decorrentes da força de trabalho versus capital, no contexto da sociedade moderna. A pesquisa revelou-nos, assim, que o ramo jurídico trabalhista carece de aprendizagem para a abordagem das provas em vídeo, sendo razoável concluir pela necessidade de preparo e alfabetização visual / digital no intuito de se proporcionar aos advogados, magistrados, membros do ministério público e a todos os profissionais envolvidos o desenvolvimento de meios cognitivos e técnicos de se proceder à correta e justa análise das provas gravadas em formato digital. Concluímos, portanto, que os operadores do Direito Processual Trabalhista pátrio precisam de preparo para enfretamento das provas em vídeo, sendo que tal alfabetização visual e digital poderia se dar através de investimento na educação jurídica, através da ministração de cursos institucionais (ordem dos advogados do Brasil, tribunais, ministério público, defensorias, universidades federais e estaduais, etc) e privados (faculdades e instituições educacionais particulares) com forte carga interdisciplinar alinhando conhecimentos teóricos aos casos práticos vivenciados.

As instituições jurídicas brasileiras já demonstram estar cientes da incidência da tecnologia no campo processual, reconhecendo a necessidade de maior preparo de seus 
profissionais, o que pode ser observado pela ministração de cursos específicos e webinários (seminários na web) ${ }^{13}$ para apreciação de provas digitais, atualmente oferecidos pelo Tribunal Superior do Trabalho, Conselho Superior da Justiça do Trabalho, Escola Nacional de Magistrados Trabalhistas, Ordem dos Advogados do Brasil e Defensoria pública do estado do Ceará, além de já observarmos obras literárias específicas sobre o tema, confirmando nossa tese de necessidade de alfabetização visual dos operadores do Direito trabalhista.

Por fim, ressaltamos que nossa conclusão pela necessidade de alfabetização dos operadores do Direito Processual trabalhista pátrio é a mesma de outros estudos realizados na esfera do direito penal (BANHATO, 2019 e MESSIAS DA SILVA, 2016), justiça militar (LÁZARO, 2018), direitos humanos e processual civil (SOUZA, 2018) os quais concluíram ser também necessária a alfabetização visual em tais esferas jurídicas.

Portanto, a tecnologia revolucionou o mundo acarretando profundas transformações em todos os setores da sociedade, inclusive no Direito Processual do Trabalho, o que desafia os profissionais, estudiosos e educadores a se adaptar, demandando, assim, um preparo específico através da alfabetização visual da área jurídica trabalhista brasileira. Aquele que não se adequar, estará, inolvidavelmente, fadado ao insucesso. Para encerrar colacionamos imagem e emblemática da era digital ora vivenciada e frase representativa do principal autor a qual o presente estudo se baseou.

\footnotetext{
${ }^{13} \mathrm{https}$ ///esa.oab.org.br/home/course/produo-de-provas-digitais-e-tutela-de-direitos-em-redes-sociaisao-vivo/62 http://www.enamat.jus.br/?p=19205

https://www.defensoria.ce.def.br/noticia/mensagens-de-texto-audio-e-fotos-em-redes-sociaisfuncionam-como-provas-em-processos-judiciais
} 


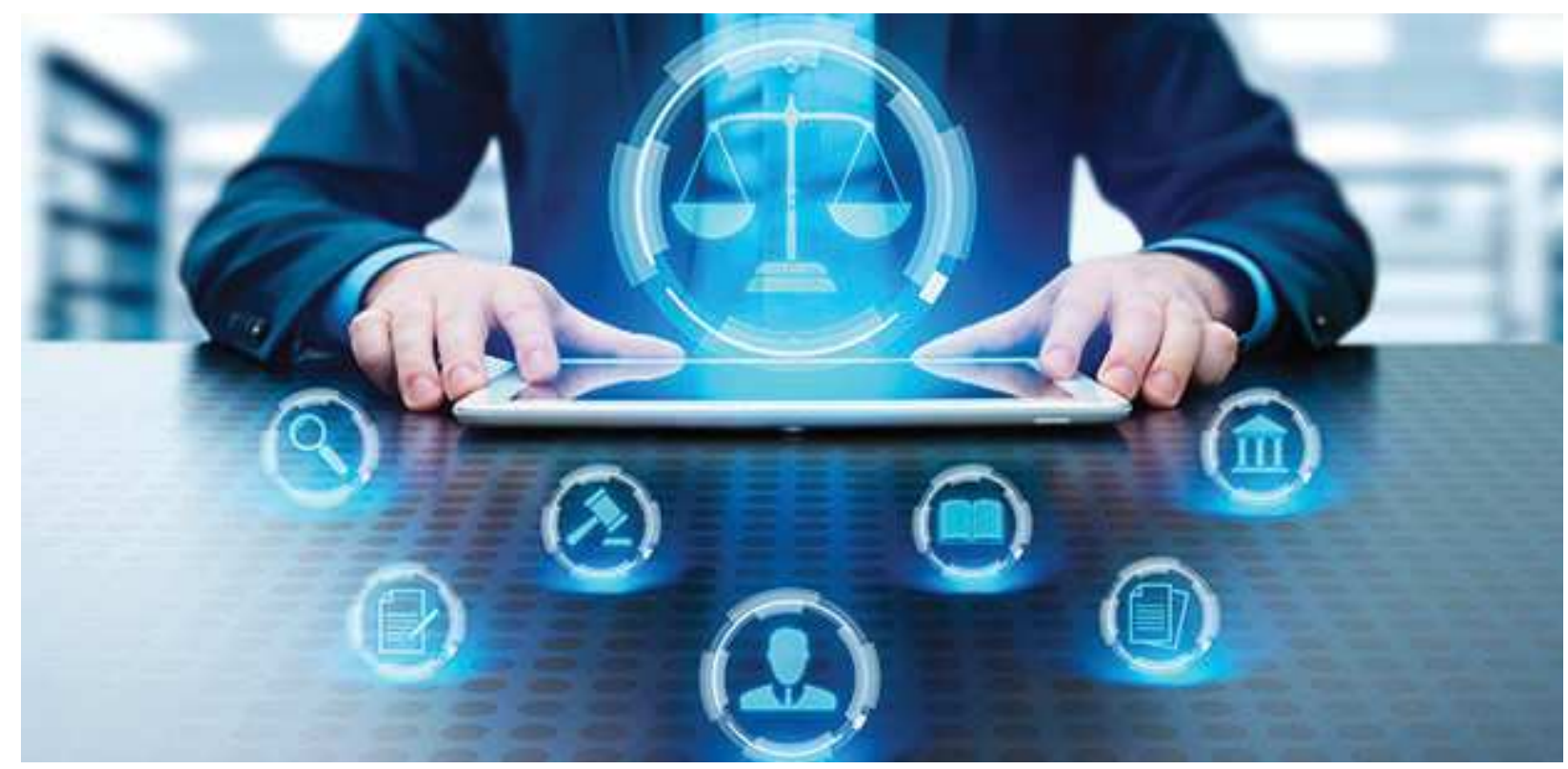

“A cada avanço tecnológico, a prática do direito se torna mais sofisticada e, proporcional a esse progresso, o sistema jurídico precisa se adaptar. Richard K. SHERWIN.” 


\section{7 - BIBLIOGRAFIA.}

ALEXY, Robert. Teoria dos direitos fundamentais. 2. ed. $4^{a}$ tiragem. São Paulo, Malheiros, 2015.

AGUiÑaGA , J. Benjamin, Confronting Confrontation in a FaceTime Generation: A Substantial Public Policy Standard to Determine the Constitutionality of Two-Way Live Video Testimony in Criminal Trials, 75 La. L. Rev. (2014) Available at: https://digitalcommons.law.lsu.edu/lalrev/vol75/iss1/10

BAUMAN, Zygmunt. Globalização: as consequências humanas, tradução Marcus Penchel, Rio de Janeiro: Jorge Zahar Editor, 1999.

BOLTANSKI, Luc.La Souffrance à Distance: Morale Humanitaire, Médias et Politique. Paris: Métailié, 1993.

CASSAR, Vólia Bomfim. Direito do Trabalho conforme a reforma trabalhista e a MP 808/2017. Editora Método, 15ª edição, São Paulo, 2017.

DA MATTA, Roberto. Relativizando: Uma Introdução à Antropologia Social, Rio de Janeiro: Rocco, 1987.

DELGADO, Mauricio Godinho. Curso de Direito do Trabalho. $15^{\text {a }}$ ed. LTr. São Paulo.

DELGADO, Mauricio Godinho. DELGADO, Gabriela Neves. A reforma trabalhista no Brasil com os comentários à Lei n. 13467/2017. 15ª ed. LTr. São Paulo.

EDMOND, G; ROQUE, M. Justicia's gaze: surveillance, evidence and the criminal trial. Surveillance \& Society, New South Wales, v. 11, n. 3, p. 252-271, ago. 2013.

EPSTEIN, L.; KING, G. Pesquisa Empírica em Direito: as regras de inferência. São Paulo: Direito GV, 2013. Disponível em: Http://handle.net/10438/11444. Acesso em 27/05/2021.

FEIGENSON, N. (2014). Visual Common Sense in Richard Sherwin \& Anne Wagner, eds., Law, Culture, \& Visual Studies 105-24.

FEIGENSON, N; SHERWIN, R; SPIESEL, C. Law in the digital age: How Visual Communication Technologies are Transforming the Practice, Theory, and Teaching of Law. NYLS Legal Studies Research Paper, Barbados, n. 5, ago. 2005. Disponível em: <https://ssrn.com/abstract=804424>. Acesso em: 21 abril. 2021.

GERHARDT, T; SILVEIRA, D.. Métodos de pesquisa. 1 ed. Rio Grande do Sul: UFRGS, 2009.

GOLDSMITH, A. J. (2010) Policing's New Visibility. British Journal of Criminology.

GOODRICH, P. (2014) Devising law: on the philosophy of legal emblems. In: Anne Wagner; Richard Sherwin. (Org.). Law, Culture and Visual Studies. Dordrecht, Heidelberg, New York and London.

GROARKE, et. al (2016). Navigating the visual turn in argument. Argumentation and Advocacy. v. 52, p. 217-263.

HERITIER, P. (2014) Law and image: towards a theory of nomograms. In: Anne Wagner; Richard Sherwin. (Org.). Law, Culture and Visual Studies. Dordrecht, Heidelberg, New York and London, Springer, 2014.

KAHAN, Dan M. Whose Eyes Are You Going to Believe? Scott v. Harris and the Perils of Cognitive Illiberalism. USA, New Haven: Faculty Scholarship Series_, Yale Law School Faculty Scholarship, 2009.

KJELDSEN, J. (2015).The study of visual and multimodal argumentation. Argumentation, v. 29, p.115-132, 2015.

LÁZARO, André F. A. (2018) A argumentação sobre a prova em vídeo em um processo criminal militar: um estudo de caso. Dissertação (Mestrado em Direito e Inovação). Universidade Federal de Juiz de Fora/Faculdade de Direito. Disponível em: . https://repositorio.ufjf.br/jspui/handleufjf/05. Acesso em 15/04/2021.

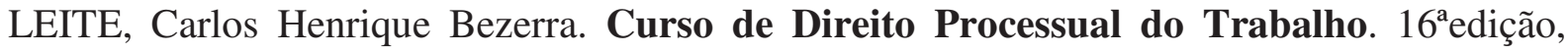
Saraiva jur, São Paulo, 2018. 
MURRAY, Michael. (2016) Visual Rhetoric and Visual Narrativity in Five Sections of a Brief. SRRN, p. 1-56, jan./fev. 2016. Disponível em: https://papers.ssrn.com/sol3/papers.cfm? abstract_id=2460357. Acesso em: 4 abril. 2021.

PORTER, E.G. (2014), Taking Images Seriously. Columbia Law Review, v.114, nº7, p. 16871782.

RICCIO, Vicente. A Lei em Tela e a Tela da Lei: O Direito e os Reality Shows. Dados, Rio de Janeiro , v. 44, n. 4, p. 773-805, 2001 . Disponível em $<$ http://www.scielo.br/scielo.php?script=sci_arttext\&pid=S001152582001000400004\&lng=pt \&nrm=iso>. acessos em 29 abr. 2021.

RICCIO, V.; VIEIRA, A; GUEDES, C. (2018) Video evidence, legal culture and court decision in brazil. In. TESSUTO G. et al. (Orgs.). Frameworks for discursive actions and practices of law. 1.ed. Newcastle: Cambridge Scholars Publishing, 2018. cap.16, p.333-347.

RICCIO, Vicente et al. (2018) Imagem e Retórica na prova em vídeo. Revista de Informação Legislativa: RIL, v. 55, n. 220, p. 85-103, out./dez. 2018. Disponível em: https://www12.senado.leg.br/ril/edicoes/55/220/ril_v55_n220_p85. Acesso em 10 de abril de 2021.

RICCIO, Vicente et al. (2016). A utilização da prova em vídeo nas cortes brasileiras: um estudo exploratório a partir das decisões criminais dos Tribunais de Justiça de Minas Gerais e São Paulo. Revista Brasileira de Ciências Criminais, São Paulo, v. 24, n. 118, p. 273 298, jan./fev. 2016.

SALGADO, Douglas, 2019. A prova em vídeo no processo penal: A interpretação da imagem e a construção da fundamentação judicial a partir da evidência imagética. Dissertação (Mestrado em Direito e Inovação). Universidade Federal de Juiz de Fora/Faculdade de Direito. Disponível em: . https://repositorio.ufjf.br/jspui/handleufjf/05. Acesso em $15 / 04 / 2021$.

SALGADO, Douglas; RICCIO, Vicente. (2020) Imagens em competição: a diferença de perspectiva na construção de julgamentos baseados em vídeo. RBSD - Revista Brasileira de Sociologia do Direito, v. 7, n. 3, p. 3-30, set./dez. 2020.

SCHIAVI, Mauro. Manual de Direito Processual do Trabalho. $10^{a}$ edição. LTr. São Paulo, 2016.

SCHOOTEN, H. (2014) Visualization between fictitious law and factual behavior: a pragmatic-institutional analysis. In: Anne Wagner; Richard Sherwin. (Org.). Law, Culture and Visual Studies. Dordrecht, Heidelberg, New York and London.

SILBEY, Jessica M. (2008). Cross-Examining Film. Race, Religion, Gender \& Class. Vol 8(17), pp. 17-46.

SILBEY, Jessica M. (2012) American trial films and the popular culture of law. Oxford Research Encyclopedia of Criminology, Oxford, UK, n. 321, Feb. 2017. Não paginado. Disponível em: . Acesso em: 4 abril. 2021.

SILBEY, Jessica M. (2004) Judges as Film Critics: New Approaches to Filmic Evidence. University of Michigan journal of law reform, [S.L], v. 37, p. 493-571, jun. 2004.

SILVA, Homero Batista da. Curso de Direito do Trabalho Aplicado. $2^{a}$ edição. Revista dos Tribunais. São Paulo, 2015.

SILVA, Beronalda Messias da. (2018) Provas em vídeo: uma análise discursiva das decisões das varas criminais da comarca de Minas Gerais e São Paulo dos anos de 2009, 2010, 2011 e 2012. Dissertação (Mestrado em Direito e Inovação). Universidade Federal de Juiz de Fora/Faculdade de Direito. Disponível em: . https://repositorio.ufjf.br/jspui/handleufjf/05. Acesso em 15/04/2021.

SOUZA, Alexandre. (2016) A Prova em Vídeo no Processo Penal sob um Enfoque de Direitos Humanos. 2016. Dissertação (Mestrado em Direito e Inovação), Universidade Federal de Juiz de Fora, Juiz de Fora, 2016. 
SHERIWIN, R. (2011). Visualizing Law in the Age of the Digital Baroque: Arabesques \& Entanglements. London, Routledge.

SHERWIN, Richard, (2018). Visual Literacy for the Legal Profession. European Journal of Legal Education.

TAIT, D. (2007), Rethinking the role of the image in justice: visual evidence and science in the trial process. Law, Probability and Risk. V. 6, 311-318.

TYLER, T. (2006). Viewing CSI and the Threshold of Guilt: Managing Truth and Justice in Reality and Fiction. Yale Law Journal.

Welsh, A., Fleming, T., Dowler, K. (2011). Constructing Crime and Justice in film: meaning and message in cinema. Contemporary Justice Review.

UOL - Disponível em https://noticias.uol.com.br/cotidiano/ultimasnoticias/2017/06/25/skatista-atropelado-na-rua-augusta-permanece-internado-policia-tentaidentificar-motorista.html. Acesso em 01/03/2021.

UOL- Disponível em https://m.folha.uol.com.br/cotidiano/2017/06/1896236-video-mostraskatistas-atacando-carro-antes-dele-invadir-trecho-interditado.shtml. Acesso em 01/03/2021. 